\title{
EFFECT OF REDUCED SODIUM CHEESE ON THE GROWTH OF PATHOGENIC BACTERIA AND INACTIVATION OF LISTERIA INNOCUA ON CHEESES USING SUPERCRITICAL FLUID EXTRACTION WITH $\mathrm{CO}_{2}$
}

\author{
A Thesis \\ presented to \\ the Faculty of California Polytechnic State University, \\ San Luis Obispo \\ In Partial Fulfillment \\ of the Requirements for the Degree \\ Master of Science in Agriculture, Specialization in: \\ Food Science and Nutrition
}

by

Suyapa Padilla Antunez

April 2016 
(C) 2016

Suyapa Padilla Antunez

ALL RIGHTS RESERVED 


\section{COMMITTEE MEMBERSHIP}

TITLE :

Effect of Reduced Sodium Cheese on the Growth of Pathogenic Bacteria and Inactivation of Listeria Innocua on Cheeses Using Supercritical Fluid Extraction with $\mathrm{CO}_{2}$

AUTHOR:

DATE SUBMITTED:

COMMITTEE CHAIR:

COMMITTEE MEMBER:

COMMITTEE MEMBER: $\quad$ Luis Castro, Ph.D.

Assistant Professor of Food Science and Nutrition
April 2016

Amanda Lathrop, Ph.D.

Associate Professor of Food Science and Nutrition

Rafael Jimenez-Flores, Ph.D.

Professor of Dairy Products Technology Center 


\begin{abstract}
Effect of Reduced Sodium Cheese on the Growth of Pathogenic Bacteria and Inactivation of Listeria Innocua on Cheeses Using Supercritical Fluid Extraction with $\mathrm{CO}_{2}$
\end{abstract}

\title{
Suyapa Padilla Antunez
}

Listeria monocytogenes continues to challenge the dairy industry in causing post-process contamination of cheeses. To reduce risk of contamination, it is crucial to understand the growth and survival of pathogenic bacteria in cheese products and to develop post-process mitigation strategies. This study evaluated the fate of pathogens in reduced and regular sodium Mozzarella cheese, and the potential of Supercritical Fluid Extraction with $\mathrm{CO}_{2}$ (SFE) to reduce Listeria innocua on Mozzarella and Queso Fresco. The survival of $L$. monocytogenes, Salmonella, and E.coli O157:H7 (2-3 log CFU/g) in reduced sodium Mozzarella (1.62\%), compared to regular sodium Mozzarella cheese $(2.15 \%)$ at $4^{\circ} \mathrm{C}$ and $12^{\circ} \mathrm{C}$ for 90 and 30 days, respectively, was evaluated. Salmonella and E. coli O157:H7 populations decreased over incubation time at both temperatures and no difference $(p<0.05)$ in reduced and regular sodium Mozzarella cheese was observed. Listeria monocytogenes population also decreased during incubation time at $4^{\circ} \mathrm{C}$ regardless of the sodium concentration in Mozzarella cheese. However, there was a difference in the population of $L$. monocytogenes for regular and reduced sodium incubated $12^{\circ} \mathrm{C}$, and its populations increased $1 \log \mathrm{CFU} / \mathrm{g}$ in reduced sodium Mozzarella cheese. Additionally, this study determined the bactericidal effect of SFE on the population of $L$. innocua, a surrogate for $L$. monocytogenes, in Mozzarella and Queso Fresco cheese (6 log CFU/g) treated with SFE at two pressures and temperatures $\left(120\right.$ bar at $40^{\circ} \mathrm{C}$ and 150 bar at $\left.50^{\circ} \mathrm{C}\right)$ for $30 \mathrm{~min}$. SFE treatment at $120 \mathrm{bar}, 40^{\circ} \mathrm{C}$ for $30 \mathrm{~min}$ decreased L. innocua by approximately 3.0 and 3.5 $\log$ CFU/g in Mozzarella and Queso Fresco cheeses, respectively. SFE at 150 bar and $50^{\circ} \mathrm{C}$ reduced $L$. innocua by approximately 3.78 and $5.2 \mathrm{log}$ CFU/g in Mozzarella and Queso Fresco cheeses, respectively. Since SFE had a minimal effect on the physico-chemical characteristics of the cheeses assayed, the results suggest SFE might be used to reduce $L$. monocytogenes in cheeses without negatively impacting product quality.

Keywords: Reduced sodium Mozzarella Cheese, Regular sodium Mozzarella Cheese, Queso Fresco, Mozzarella Cheese, SFE, L. monocytogenes, Salmonella, E.coli O157:H7, L. innocua 


\section{ACKNOWLEDGMENTS}

I would like to thank God for giving me the opportunity to meet these wonderful people in CalPoly and for giving me the strength to keep going. I wish to extend my deepest gratitude to my advisor, Dr. Amanda Lathrop. Thank you for giving me the opportunity to work in your laboratory and for contributing to my professional and personal growth; without this opportunity, I wouldn't be graduating today. I'm also very grateful to my committee members. Dr. Jimenez, thank you for your guidance, support, and encouragement in the earlier part of the research and through graduate school. Dr. Castro, thank you for your advice through graduate school. I would also like to thank Dr. Celine Hayden for letting me use the SFE machine, as well as giving me her valuable time to assist me in using the SFE machine. Dr. Andrew Schaffner, thank you for helping me to analyze all the data. I appreciated Andrea Laubscher for assisting me with laboratory supplies. I also want to express my gratitude to Dr. Trujillo for mentoring and motivating me.

I am also very thankful to the current graduate students in the food safety lab for helping me with my experiments, especially Toni DeSena, Franca Rossi. Also, thank you to all of the undergraduate students for their assistance and their contributions during my challenge studies, especially Thei Soe, Celina To, Alvin Loi, Christopher John Craddock, and Michelle Reimer.

Finally, I'm grateful to my family and friends, especially to Nazneen Malik, Michael Chen, Carina and Nereida Rojas, and Georgia Reeves, for their support during this time, particularly for encouraging me to finish and for cheering me up. 


\section{TABLE OF CONTENTS}

Page

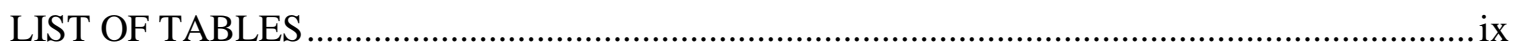

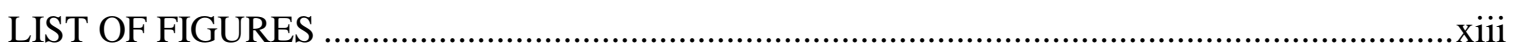

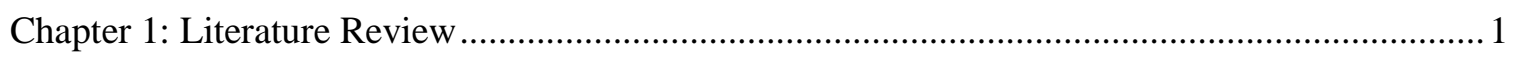

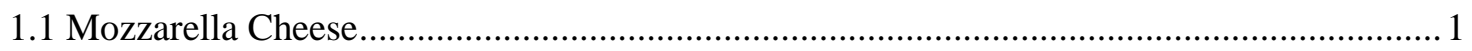

1.1.1 Mozzarella Cheese: Description and Manufacturing .............................................. 1

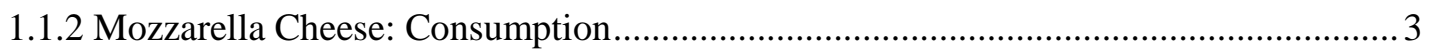

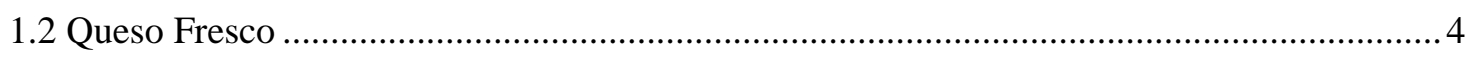

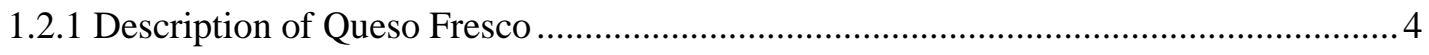

1.3 Relationship of Foodborne Pathogens with Mozzarella Cheese and Queso Fresco ..............4

1.4 Foodborne Illness and Contamination of Cheeses...........................................................

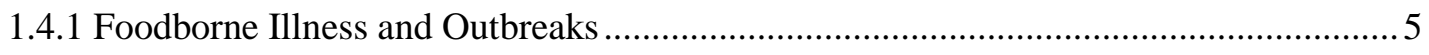

1.4.2 Characteristics of Microorganisms Found in Cheese ............................................ 8

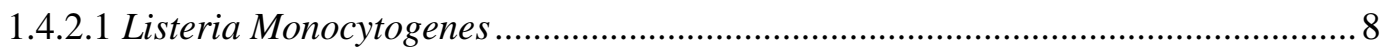

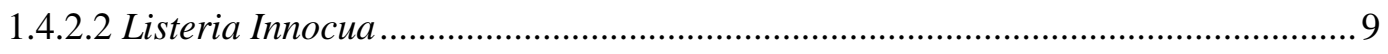

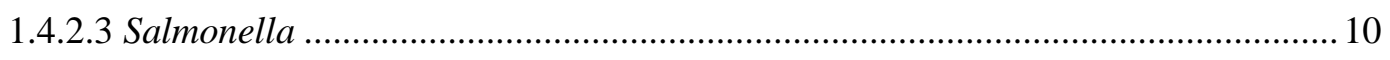

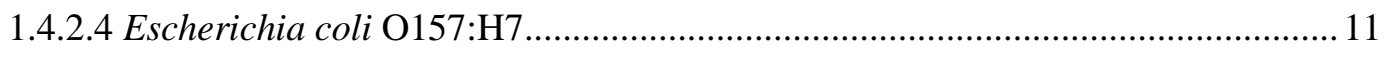

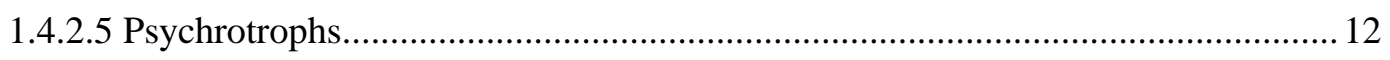

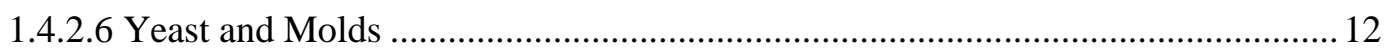

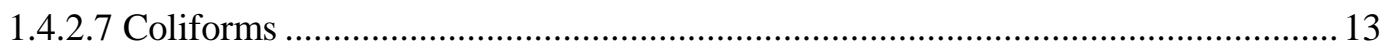

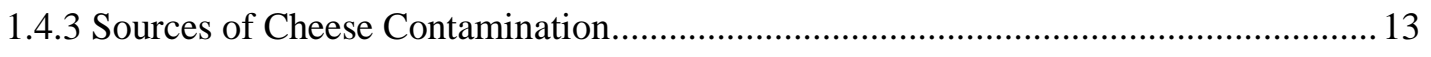

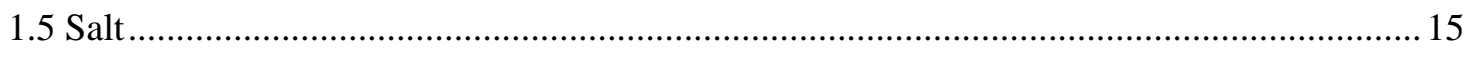

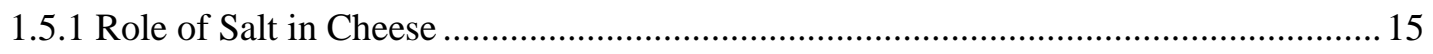

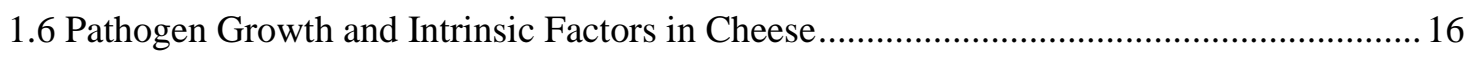




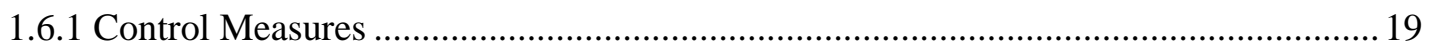

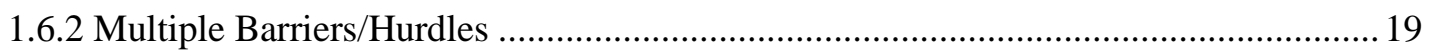

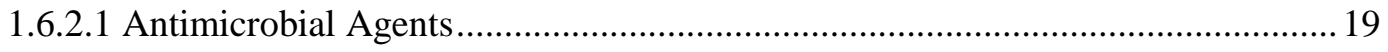

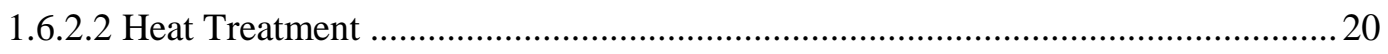

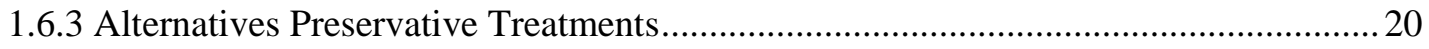

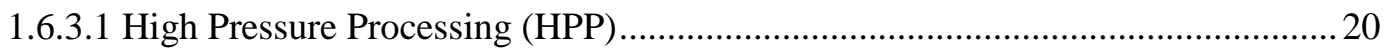

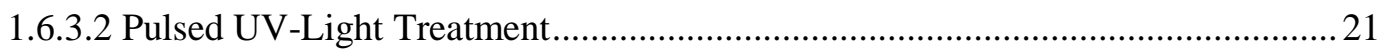

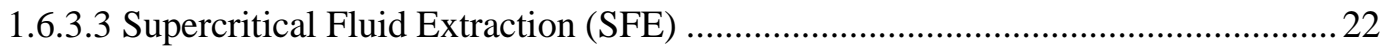

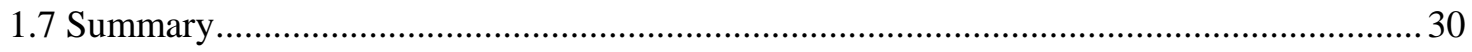

Chapter 2: Effect of sodium reduction on the growth of pathogens in Mozzarella Cheese ........... 37

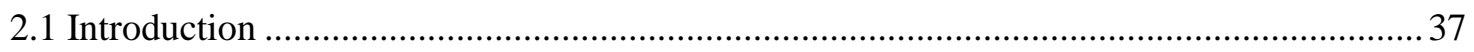

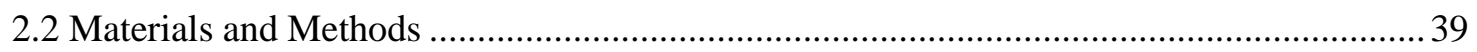

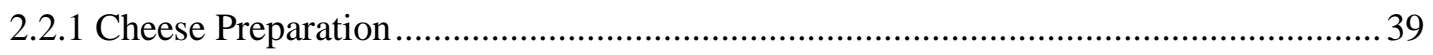

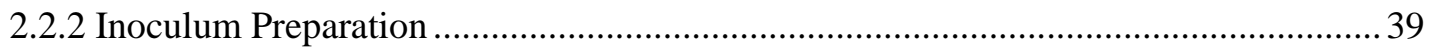

2.2.3 Pathogen Inoculation of Reduced and Regular Sodium Mozzarella Cheese ............... 40

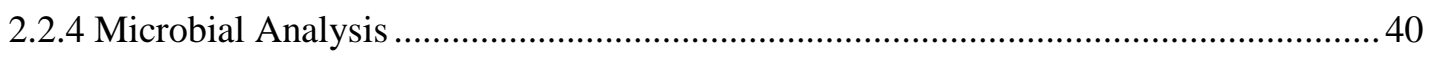

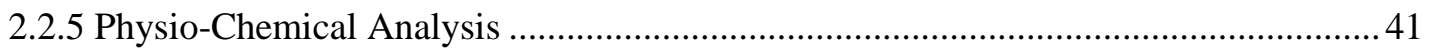

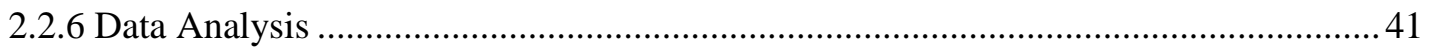

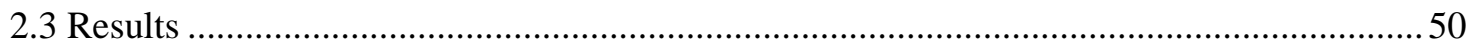

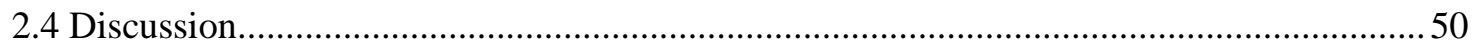

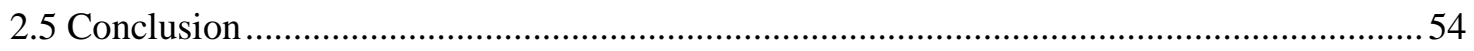

Chapter 3: Reduction of Listeria innocua on Queso Frescoand Mozzarella Cheese using

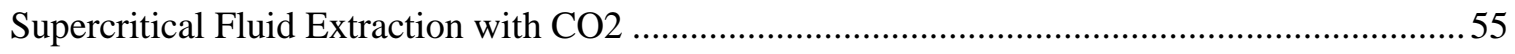

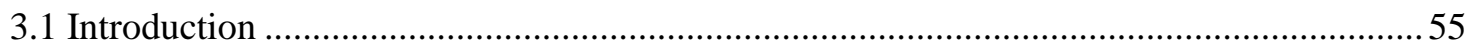

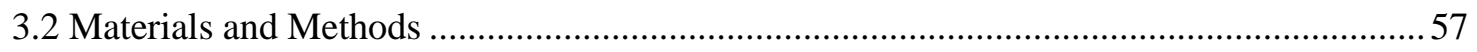

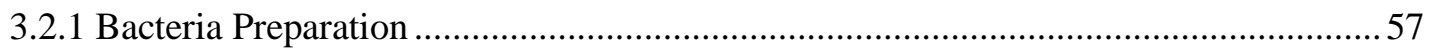




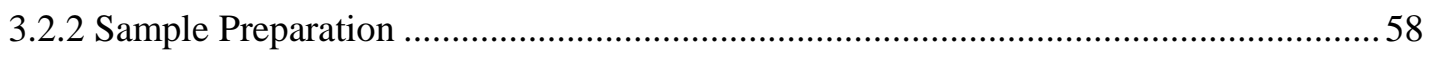

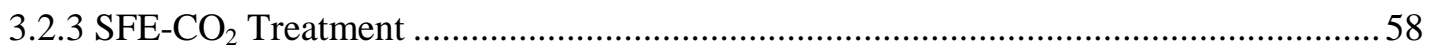

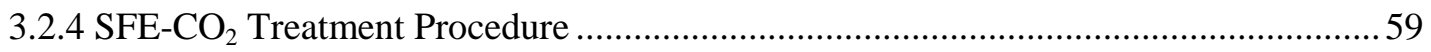

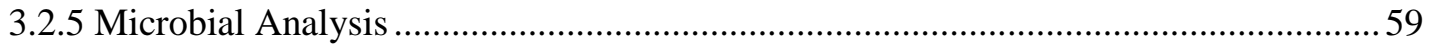

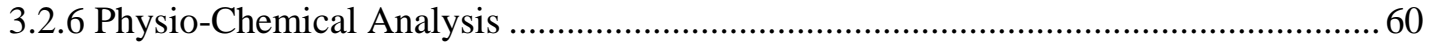

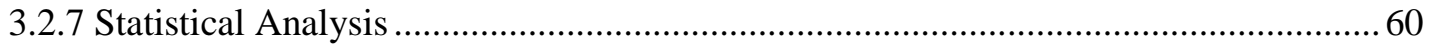

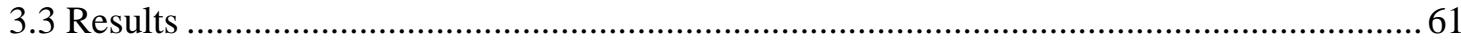

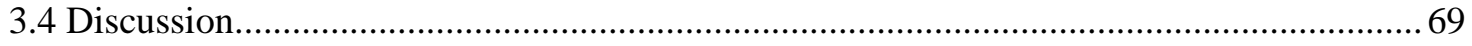

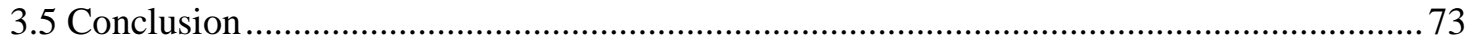

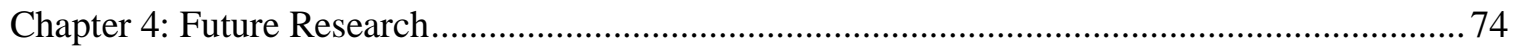

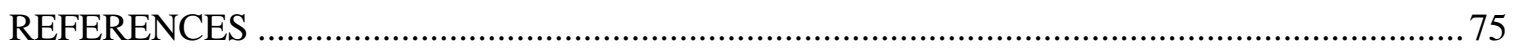

APPENDICES

Appendix A: Results of Mozzarella Cheese Challenge …....................................................... 85

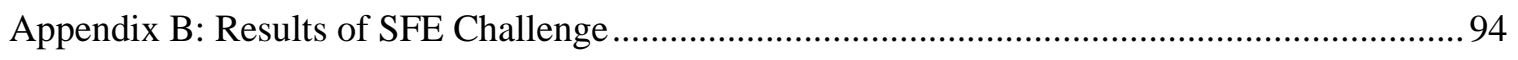

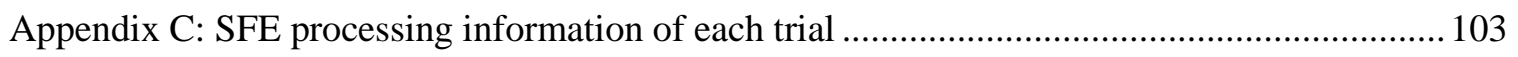




\section{LIST OF TABLES}

Table

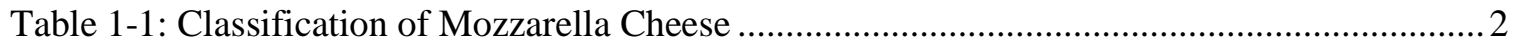

Table 1-2: Composition of Mozzarella Cheese....................................................................... 2

Table 1-3: List of Recalls and Food Outbreaks in Mozzarella and Queso Fresco Cheese ............. 6

Table 1-4: Effect of SFE as Antimicrobial in Different Food Matrix........................................... 32

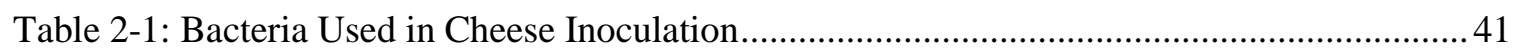

Table 2-2: Behavior of L. monocytogenes $(\log \mathrm{CFU} / \mathrm{g}$ ) in Regular and Reduced Sodium

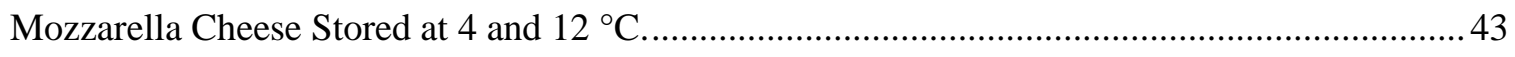

Table 2-3: Behavior of E. coli O157:H7 (log CFU/g) in Regular and Reduced Sodium

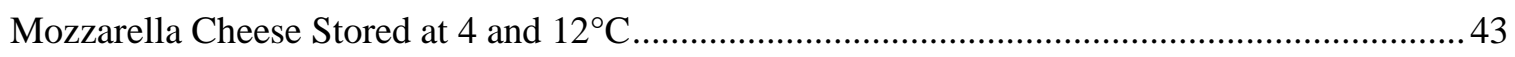

Table 2-4: Behavior of Salmonella (log CFU/g) in Regular and Reduced Sodium Mozzarella

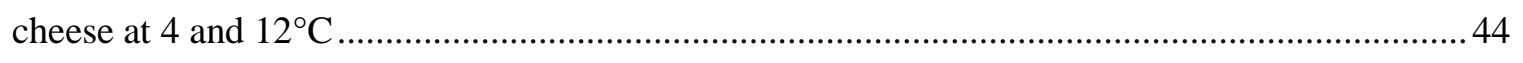

Table 2-5: Behavior of Psychrotrophs (log CFU/g) in Regular and Reduced Sodium

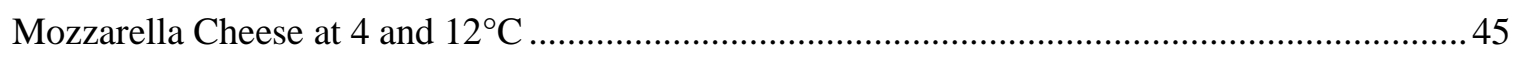

Table 2-6: Behavior of Coliforms in (log CFU/g) Regular and Reduced Sodium Mozzarella

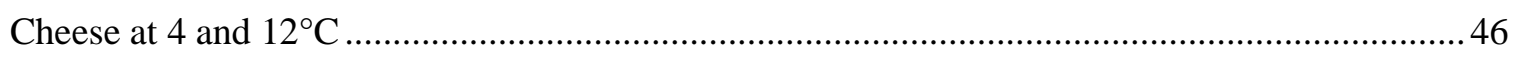

Table 2-7: Behavior of Yeast (log CFU/g) in Regular and Reduced Sodium Mozzarella

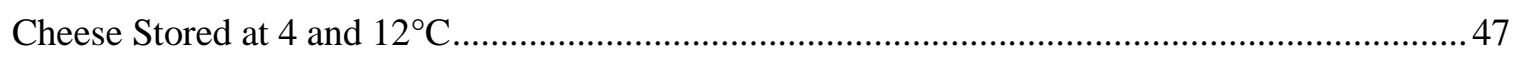

Table 2-8: Behavior of Mold (log CFU/g) in Regular and Reduced Sodium Mozzarella

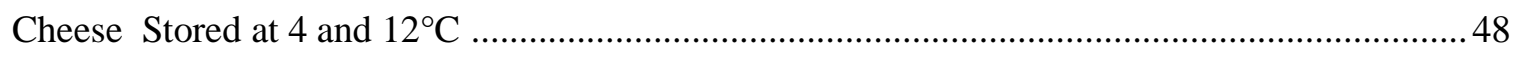

Table 2-9: Water Activity of Regular and Reduced Sodium Mozzarella Cheese Stored

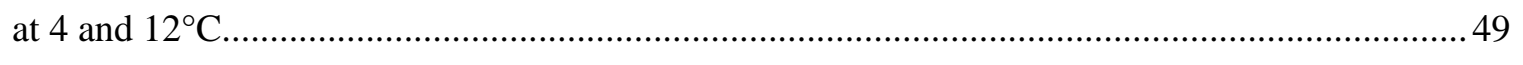

Table 2-10: $\mathrm{pH}$ of Regular and Reduced Sodium Mozzarella Cheese Stored at 4 and $12^{\circ} \mathrm{C} \ldots \ldots . . .49$

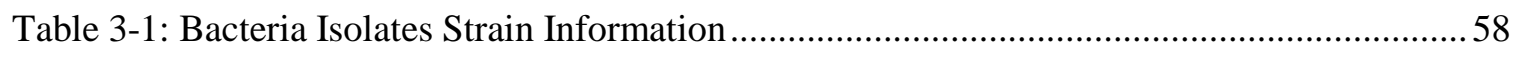


Table 3-2: Effect of SFE on L. innocua Population (log CFU/g) in Queso Fresco Cheese. 62

Table 3-3: Effect of SFE on the Growth L. innocua $(\log$ CFU/g) in Mozzarella Cheese..... 62

Table 3-4: Effect of SFE on Psychrotroph Population (log CFU/g) in Queso Fresco Cheese ...... 63

Table 3-5: Effect of SFE on Coliforms Population (log CFU/g) in Queso Fresco Cheese .64

Table 3-6: Effect of SFE on the Growth of Yeast Population (log CFU/g) in Queso Fresco

Cheese. 64

Table 3-7: Effect of SFE on pH of Queso Fresco Cheese .65

Table 3-8: Effect of SFE on pH on Mozzarella Cheese. .66

Table 3-9: Effect of SFE on Water Activity (Aw) in Queso Fresco Cheese .66

Table 3-10: Effect of SFE on Water Activity (Aw) in Mozzarella Cheese

Table A-1: Behavior of L. monocytogenes (log CFU/g) in Regular and Reduced Sodium

Mozzarella Cheese Stored at 4 and $12 \mathrm{C}$ on Trial 1 and Trial 2 .85

Table A-2: Behavior of E. coli O157:H7 (log CFU/g) in Regular and Reduced Sodium Mozzarella Cheese Stored at 4 and $12^{\circ} \mathrm{C}$ on Trial 1 and Trial 2. 86

Table A-3: Behavior of Salmonella (log CFU/g) in Regular and Reduced Sodium Mozzarella

Cheese Stored at 4 and $12^{\circ} \mathrm{C}$ on Trial 1 and Trial 2

Table A-4: Behavior of Psychrotroph (log CFU/g) in Regular and Reduced sodium

Mozzarella Cheese Stored at 4 and $12^{\circ} \mathrm{C}$ on Trial 1 and Trial 2.

Table A-5: Behavior of Coliforms (log CFU/g) in Regular and Reduced Sodium Mozzarella

Cheese Stored at 4 and $12^{\circ} \mathrm{C}$ on Trial 1 and Trial $2 \ldots$

Table A-6: Behavior of Yeast (log CFU/g) in Regular and Reduced Sodium Mozzarella

Cheese Stored at 4 and $12^{\circ} \mathrm{C}$ on Trial 1 and Trial 2

Table A-7: Behavior of Mold (log CFU/g) in Regular and Reduced Sodium Mozzarella

Cheese Stored at 4 and $12^{\circ} \mathrm{C}$ on Trial 1 and Trial 2 91

Table A-8: pH of Regular and Reduced Sodium Mozzarella Cheese Stored at 4 and $12^{\circ} \mathrm{C}$ on Trial 1 and Trial 2 92 
Table A-9: Water Activity (Aw) of Regular and Reduced Sodium Mozzarella Cheese stored at 4 and $12^{\circ} \mathrm{C}$ on Trial 1 and Trial 2

Table B-1: Effect of SFE on L. innocua Population (log CFU/g) in Queso Fresco Cheese for Trial 1 and Trial 2

Table B-2: Effect of SFE on L. innocua Population (log CFU/g) in Mozzarella Cheese for Trial 1 and Trial 2 . .95

Table B-3: Effect of SFE on Coliforms Population (log CFU/g) in Queso Fresco Cheese for Trial 1 and Trial 2 .96

Table B-4: Effect of SFE on Psychrotroph Population (log CFU/g) in Queso Fresco Cheese for Trial 1 and Trial 2 .

Table B-5: Effect of SFE on Yeast Population (log CFU/g) in Queso Fresco Cheese for Trial 1 and Trial 2 .98

Table B-6: Effect of SFE on the pH of Queso Fresco Cheese for Trial 1 and Trial 2 .99

Table B-7: Effect of SFE on the pH of Mozzarella Cheese for Trial 1 and Trial 2

Table B-8: Effect of SFE on the Water Activity (Aw) of Queso Fresco Cheese Trial 1 and Trial 2 101

Table B-9: Effect of SFE on the Water Activity (Aw) of Mozzarella Cheese Trial 1 and

Trial 2 102

Table C-1: Mozzarella Cheese Treated with SFE at 120 Bar, $40^{\circ} \mathrm{C}$ for 30 minutes for Trial $1 . .103$ Table C-2: Mozzarella Cheese Treated with SFE at 120 Bar, $40^{\circ} \mathrm{C}$ for 30 minutes for Trial $2 . .104$ Table C-3: Mozzarella Cheese Treated with SFE at 150 Bar, $50^{\circ} \mathrm{C}$ for 30 minutes for Trial $1 . .104$ Table C-4: Mozzarella Cheese Treated with SFE at 150 Bar, $50^{\circ} \mathrm{C}$ for 30 minutes for Trial 2 .. 105 Table C-5: Queso Fresco Cheese Treated with SFE at 120 Bar, $40^{\circ} \mathrm{C}$ for 30 minutes for Trial 1 105

Table C-6: Queso Fresco Cheese Treated with SFE at 120 Bar, $40^{\circ} \mathrm{C}$ for 30 minutes for Trial 2 106 
Table C-7: Queso Fresco Cheese Treated with SFE at 150 Bar, $50^{\circ} \mathrm{C}$ for 30 minutes for

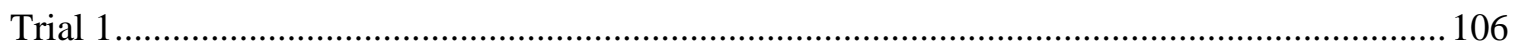

Table C-8: Queso Fresco Cheese Treated with SFE at 150 Bar, $50^{\circ} \mathrm{C}$ for 30 minutes for

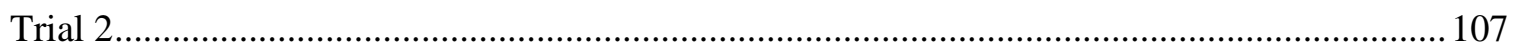




\section{LIST OF FIGURES}

Figure Page

Figure 1-1: SFE-CO2 Pressure-temperature phase diagram....................................................... 23

Figure 1-2: Flow diagram of a supercritical fluid extraction system ..........................................24

Figure 3-1: Appearance of Queso Fresco after (top) and before SFE (bottom) treatment at

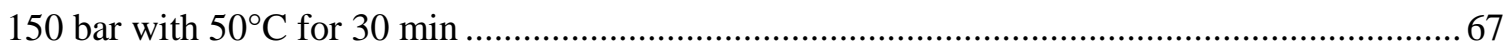

Figure 3-2: Appearance of Queso Fresco before (left) and after SFE (right) treatment at 120 bar with $40^{\circ} \mathrm{C}$ for $30 \mathrm{~min}$. .68

Figure 3-3: Appearance of Mozzarella cheese before (top) and after SFE (bottom) treatment at 150 bar with $50^{\circ} \mathrm{C}$ for $30 \mathrm{~min}$ .68

Figure 3-4: Appearance of Mozzarella cheese after (left) and before SFE (right) treatment at 120 bar with $40^{\circ} \mathrm{C}$ for $30 \mathrm{~min}$ 69

Figure 3-5: Appearance of Mozzarella cheese after SFE treatment at 120 bar with $40^{\circ} \mathrm{C}$ for $30 \min$ 69

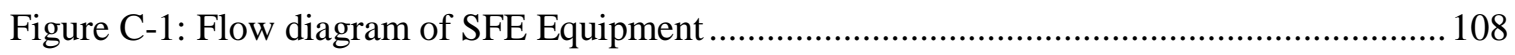

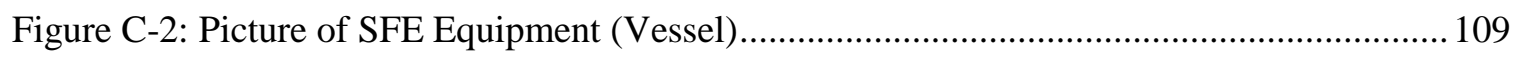

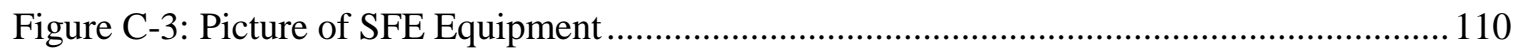

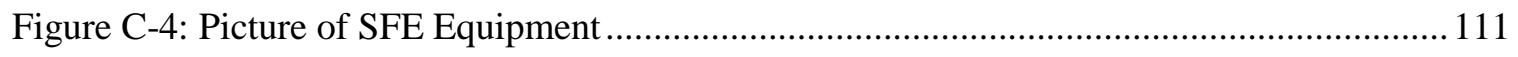

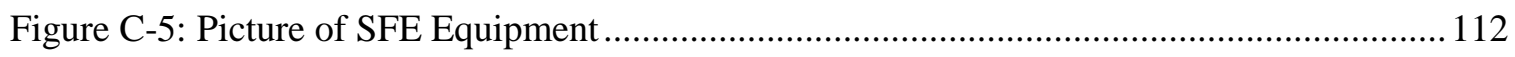

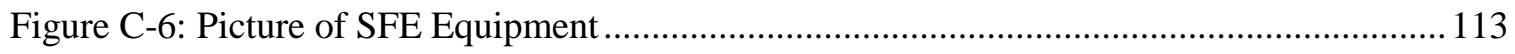

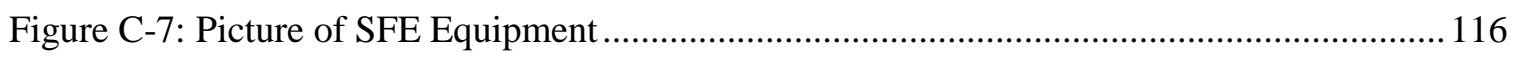

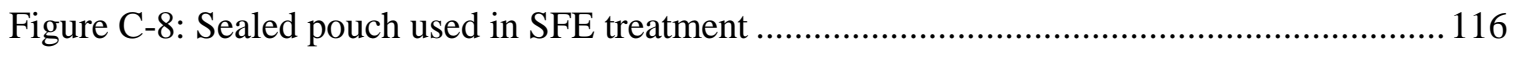




\section{CHAPTER 1: LITERATURE REVIEW}

Cheese is defined as a curd of milk turned solid by protein (casein) coagulation with rennet (Fernandes, 2009). Cheese is a complex food that provides nutrients necessary for a healthy diet, containing 9\% protein, $11 \%$ phosphorus, and $27 \%$ of calcium (Johnson, Kapoor, McMahon, McCoy, \& Narasimmon, 2009). Daily, Americans-depending on age and gendershould consume 2-3 cups of dairy products to meet with Dietary Guidelines for Americans and MyPlate Food Guidance System (Bentley, 2014).

In the United States, consumption of cheese has grown remarkably, from 16.4 in 1970 to 36.0 pounds per person in 2012 (Bentley, 2014). Mozzarella cheese-within the variety of Italian cheeses - has been the preferred choice for Americans since the consumption has escalated from 1.1 pounds per person in 1970 to 11.51 pounds per person in 2012 (USDA, 2014). Queso fresco, a fresh type of cheese, is one of the most in prevalent cheeses included in the Hispanic diet. The Hispanic population is speedily escalating in the USA; creating a high demand for Hispanic cheeses, particularly Queso Fresco. Most recent data shows that the consumption of Hispanic cheeses has grown from 0.25 pounds per person in 1996 to 0.71 pounds per person in 2012 (Gadotti, Nelson, \& Diez-Gonzalez, 2014; USDA, 2014). Due to a high demand for cheeses and increased consumption, the food industry needs to deliver safe, healthy, quality products with a longer shelf life.

\subsection{Mozzarella Cheese}

\subsubsection{Mozzarella Cheese: Description and Manufacturing}

Mozzarella is a soft unripened cheese classified within the pasta-filata cheese family. It was originally produced by Buffalo milk, and created in Battipaglia, Italy. Cheese is produced from cow's milk in United States. Pasta-filata cheeses are characterized by their smooth-stretchy texture and melting properties resulting from stretching the curd in hot water (Jana \& Mandal, 
2011). Mozzarella cheese is classified into five different categories based on the moisture and fat on dry matter content (USDA, 2012,

Table 1-1). The main components of mozzarella cheese are water, fat, protein, and salt (Jana \& Mandal, 2011, Table 1-2). The process of making mozzarella cheese is straightforward; the steps involved in the manufacturing of mozzarella cheese are:

1. Pasteurization and homogenization of milk: Whole milk or partially skimmed is pasteurized.

2. Acidification of milk by direct or biological acidification: When milk reaches $37^{\circ} \mathrm{C}$, starter cultures or organic acid is added in order to lower the $\mathrm{pH}$ between $5.0-5.3$

Table 1-1: Classification of Mozzarella Cheese

\begin{tabular}{llll}
\hline Type of Mozzarella Cheese & Moisture & Fat on dry matter & $\mathrm{pH}$ \\
\hline Regular & $52 \%-60 \%$ & $<45 \%$ & $5.1-5.4$ \\
Low-moisture & $45 \%-52 \%$ & $<45 \%$ & $5.1-5.4$ \\
Part-skim & $52 \%-60 \%$ & $30 \%-45 \%$ & $5.1-5.4$ \\
Low moisture Part-skim & $45 \%-52 \%$ & $30 \%-45 \%$ & $5.1-5.4$ \\
Lite & $52 \%-60 \%$ & $<10.8 \%$ & $<5.3$ \\
\hline
\end{tabular}

Source: (Jana \& Mandal, 2011)

Table 1-2: Composition of Mozzarella Cheese

\begin{tabular}{ll} 
Moisture (\%) & $48.59-50.51$ \\
Fat (\%) & $25.85-27.25$ \\
Protein (\%) & $20.06-20.83$ \\
Lactose (\%) & 1.58 \\
Ash (\%) & $2-3.62$ \\
Salt (\%) & $0.90-2.17$ \\
Acidity (\%) & $0.61-0.76$ \\
\hline \multicolumn{1}{c}{ Source: (Jana \& Mandal, 2011) } \\
\multicolumn{2}{r}{ In direct acidification, organic acid, such as lactic acid, citric acid, or acetic acid is used. } \\
In biological acidification, starter cultures are used, particularly thermophilic lactic acid bacteria.
\end{tabular}


Conventionally, a combination of Streptococcus thermophiles, Lactobacillus helveticus and Lactobacillus delbrueckii subsp. bulgaricus are used in 1:1 ratio at $2.0 \% \mathrm{w} / \mathrm{v}$.

1. Addition of rennet to form a curd: After the $\mathrm{pH}$ drops to 5.0-5.3, rennet is added $(1.5 \mathrm{~g} / 100 \mathrm{~kg}$ milk) to coagulate the milk. Rennet is an enzyme obtained from animals, vegetable enzyme, microbial or genetically modified organism sources that coagulates milk by breaking down the $\mathrm{k}$ - casein of the milk fat globule membrane (MFGM) into para $\kappa$ - casein and glycomacropeptide (Fox, Guinee, and Cogan, 2000).

2. Cutting of the Curd: Approximately 40 minutes after rennet addition, the curd forms, and it is cut into large pieces.

3. Cooking the curd: Curd and whey are cooked and stirred at a low temperature of $37^{\circ} \mathrm{C}$ to $42^{\circ} \mathrm{C}$ for 40 minutes. The minimal temperature helps to retain high-moisture content.

4. Drainage of whey: When the curd has a $\mathrm{pH}$ 6.2-6.3, it is then separated from the whey.

5. Plasticizing: Curd is heated and stretched in warm water and formed into shapes

6. Salting: Curd is salted, different methods of salting can be applied—dry salting, brine salting, and hot salting

7. Packaging and storage of cheese: After salting, cheese is cooled, and finally packaged and stored at $4^{\circ} \mathrm{C}$ (Jana \& Mandal, 2011; Mijan et. al., 2010).

\subsubsection{Mozzarella Cheese: Consumption}

Mozzarella cheese has become very popular in the USA, since it is used as a pizza ingredient and as a snack (string cheese). Of all the cheese manufactured in the US, mozzarella represents $34.3 \%$ of the total cheese volume. In addition, Mozzarella cheese per capita consumption has grown from 1.19 pounds per day in 1970 to 11.5 in 2012 . Most recently, mozzarella cheese production in the USA was nearly 4 (3.92) billion pounds in $2014,6 \%$ higher than the previous year. 
In the western USA, California represents one of the major producers of mozzarella cheese comprising $36.8 \%$ of mozzarella cheese production within the United States in 2014.

\subsection{Queso Fresco}

\subsubsection{Description of Queso Fresco}

Queso fresco is a soft, fresh unripened white cheese of Hispanic origin with low meltability and crumbly texture. It is typically produced with no starter culture, and has a shelf life of 14 days from manufacture. This cheese also has high moisture content of $46-51 \%$, a pH of $6.1,18-22 \%$ fat, $19-22 \%$ protein, and $2-3 \%$ salt. There is no FDA Standard of Identity for Hispanic cheeses, which challenges producers and consumers to clearly identify the product (Chandan, Marin, Nakrani, \& Zehner, 1979; Van Hekken \& Farkye, 2003). The manufacture of Queso Fresco involves whole or part skim milk warmed to $30-32^{\circ} \mathrm{C}$, with the addition of rennet (Chymosin), traditionally $\mathrm{CaCl}_{2}(0.1 \%)$ are added to the milk; and eventually combined with organic acids - direct acidification. When the curd is set, it is cut into 1 -cm cubes, cooked at $39^{\circ} \mathrm{C}$ for 30 minutes, and milled. Finally, with the curd at a $\mathrm{pH}$ of about 6.3 , the whey is drained, and the curd is dry salted. Then, the dry curd is molded, pressed overnight, and packaged into $12 \mathrm{oz}$. packages. Cheeses in bulk size and brick shape is called 'Adobera'(Paul \& Van Hekken, 2011;Torres-Llanez, Vallejo-Cordoba, Díaz-Cinco, Mazorra-Manzano, \& González-Córdova, 2006; Van Hekken \& Farkye, 2003;). Queso fresco is unique, and characterized differently from other cheese processing, because of the milling step, which is necessary for its crumbly texture (Van Hekken et al., 2003).

\subsection{Relationship of Foodborne Pathogens with Mozzarella Cheese and Queso Fresco}

Although cheeses, particularly mozzarella cheeses are made of pasteurized milk, occasionally pathogenic bacteria can contaminate the cheese causing food recalls and outbreaks. Cheeses, including mozzarella cheese, have been involved in such cases (Table 3). There have 
been a few remarkable cases. In 1981, a multistate outbreak of Salmonella caused 321 cases and two deaths from mozzarella cheese made from pasteurized milk. Likewise, eight years later, another multistate outbreak with 164 cases occurred by Salmonella (Hedberg et al., 1992). In 2013, mozzarella cheese was recalled due to potential contamination with Escherichia coli O121. The cheeses were produced by Farm Rich or Market Day brand (Kousta, Mataragas, Skandamis, \& Drosinos, 2010; Kleinman, 2013). Listeria monocytogenes has caused outbreaks or recalls in mozzarella cheese, yet its incidence in mozzarella cheese is low compared to Queso fresco where it has been the cause of several outbreaks.

Queso fresco has a high incidence of outbreaks because of its chemical and nutritional attributes; making this type of cheese more vulnerable to the growth of microbial organisms (Gadotti, Nelson, \& Diez-Gonzalez, 2014). Sampling from Queso Fresco manufacturing plants have tested positive for pathogens. Kabuki et al., (2004) found Listeria monocytogenes in $6.3 \%$ of cheese made of pasteurized milk and in $11 \%$ of processing plant installations such as crates, drains, and floor samples. Also, Queso Fresco produced from illegal—raw-milk has been found; unpasteurized milk has been sold within the Hispanic communities and caused Salmonellosis by Salmonella Serotype typhimurium DT104 in Washington State (Villar et al., 2015). Queso fresco is one of the most common cheeses most involved in recalls and outbreaks over the last three decades in the USA reported by the CDC (Table 1-3).

\subsection{Foodborne Illness and Contamination of Cheeses}

\subsubsection{Foodborne Illness and Outbreaks}

Pathogenic bacteria can grow on cheese and cause foodborne illness. Several cases of foodborne illness, such as salmonellosis and listeriosis, are linked with the consumption of contaminated cheese. Symptoms depend on the type of microorganism causing the 
contamination; however, most foodborne illnesses are characterized by nausea, vomiting, abdominal cramps, and diarrhea.

Gould et al. (2014) defined a foodborne illness outbreak as the prevalence of two or more cases of an illness caused by the ingestion of the same food. They reported that 96 outbreaks were caused by the consumption of cheese from 1998 to 2011. Of those outbreaks from cheese, there were 1,882 cases of illnesses, 230 cases of hospitalization, and 6 cases of death. In this same period, dairy products were rated as the second leading cause of foodborne illness, second to leafy products. Dairy products were also the number one cause of hospitalization, responsible for $16 \%$ of all food-related hospitalizations, as well as being the second leading cause of food related death (10\% of deaths) (Painter et al., 2013).

Table 1-3: List of Recalls and Food Outbreaks in Mozzarella and Queso Fresco Cheese

\begin{tabular}{|c|c|c|c|c|c|}
\hline $\begin{array}{ll}\begin{array}{l}\text { Type } \\
\text { cheese }\end{array} & \text { of } \\
\end{array}$ & Pathogen & Cases & Deaths & Type of Association & Reference \\
\hline Mozzarella & Salmonella spp. & 321 & 2 & Foodborne outbreak & $\begin{array}{l}\text { Hedberg et al., } \\
1992\end{array}$ \\
\hline Mozzarella & Salmonella spp. & 164 & n.a & Foodborne outbreak & $\begin{array}{l}\text { Hedberg et al., } \\
1993\end{array}$ \\
\hline Queso Fresco & L.monocytogenes & 142 & 48 & Foodborne outbreak & $\begin{array}{l}\text { Kousta et. al., } \\
2010\end{array}$ \\
\hline Queso Fresco & Salmonella & 110 & 0 & Foodborne outbreak & $\begin{array}{l}\text { Kousta et. al., } \\
2010\end{array}$ \\
\hline Queso Fresco & Salmonella & 54 & 0 & Foodborne outbreak & $\begin{array}{l}\text { Kousta et. al., } \\
2010\end{array}$ \\
\hline Queso Fresco & Salmonella & 17 & 0 & Foodborne outbreak & $\begin{array}{l}\text { Kousta et. al., } \\
2010\end{array}$ \\
\hline Mozzarella & Norovirus & 6 & n.a & Foodborne outbreak & CSPI,2011 \\
\hline Queso Fresco & L.monocytogenes & 13 & 0 & Foodborne outbreak & $\begin{array}{l}\text { Kousta et. al., } \\
2010\end{array}$ \\
\hline Queso Fresco & S. Newport & 38 & n.a & Foodborne outbreak & CSPI,2011 \\
\hline Mozzarella & S. Newport & 4 & n.a & Foodborne outbreak & CSPI,2011 \\
\hline Mozzarella & Norovirus & 9 & n.a & Foodborne outbreak & CSPI,2011 \\
\hline Queso Fresco & L.monocytogenes & 6 & 1 & Foodborne outbreak & $\begin{array}{l}\text { Kousta et. al., } \\
2010\end{array}$ \\
\hline Queso Fresco & C. jejuni & 11 & 0 & Foodborne outbreak & $\begin{array}{l}\text { Kousta et. al., } \\
2010\end{array}$ \\
\hline Mozzarella & S. Typhimurium & 4 & n.a & Foodborne outbreak & CSPI,2011 \\
\hline
\end{tabular}




\begin{tabular}{|c|c|c|c|c|c|}
\hline Queso Fresco & L.monocytogenes & 15 & 3 & Foodborne outbreak & $\begin{array}{l}\text { Kousta et. al. } \\
2010\end{array}$ \\
\hline Queso Fresco & E. coli O157:H7 & 3 & 0 & Foodborne outbreak & $\begin{array}{l}\text { Kousta et. al. } \\
2010\end{array}$ \\
\hline Queso Fresco & L.monocytogenes & 14 & n.a & Foodborne outbreak & $\begin{array}{l}\text { Kousta et. al., } \\
2010\end{array}$ \\
\hline Queso Fresco & Brucella & 2 & 0 & Foodborne outbreak & $\begin{array}{l}\text { Kousta et. al., } \\
2010\end{array}$ \\
\hline Queso Fresco & Shigella & 2 & n.a & Foodborne outbreak & CSPI,2011 \\
\hline Queso Fresco & Salmonella & 12 & n.a & Foodborne outbreak & CSPI,2011 \\
\hline Queso Fresco & S. Typhimurium & 3 & n.a & Foodborne outbreak & CSPI,2011 \\
\hline Queso Fresco & Salmonella & 2 & n.a & Foodborne outbreak & CSPI,2011 \\
\hline Queso Fresco & L.monocytogenes & 8 & 0 & Foodborne outbreak & $\begin{array}{l}\text { Kousta et. al., } \\
2010\end{array}$ \\
\hline Queso Fresco & S. dublin & 4 & 0 & Foodborne outbreak & CSPI,2011 \\
\hline Queso Fresco & $\begin{array}{l}\text { L. } \\
\text { monocytogenes }\end{array}$ & 5 & 0 & Foodborne outbreak & $\begin{array}{l}\text { Kousta et. al., } \\
2010\end{array}$ \\
\hline Queso Fresco & Salmonella & 4 & 0 & Foodborne outbreak & $\begin{array}{l}\text { Kousta et. al., } \\
2010\end{array}$ \\
\hline Queso Fresco & $\begin{array}{l}\text { L } \\
. \text { monocytogenes }\end{array}$ & -- & -- & Food recalls & CSPI,2011 \\
\hline Queso Fresco & B. Spp. & 3 & n.a & Foodborne outbreak & CSPI,2011 \\
\hline Mozzarella & Norovirus & 21 & n.a & Foodborne outbreak & CDC, 2011 \\
\hline Queso Fresco & C. jejuni & 10 & n.a & Foodborne outbreak & CSPI,2011 \\
\hline Queso Fresco & C. jejuni & 3 & 0 & Foodborne outbreak & CDC,2013 \\
\hline Queso Fresco & L.monocytogenes & -- & -- & Food recalls & CDC,2013 \\
\hline Queso Fresco & L.monocytogenes & -- & -- & Food recalls & CDC,2013 \\
\hline Queso Fresco & L.monocytogenes & -- & -- & Food recalls & CDC,2013 \\
\hline Queso Fresco & S. aureus & -- & -- & Food recalls & CDC,2013 \\
\hline Queso Fresco & $\begin{array}{l}\text { L. } \\
\text { monocytogenes }\end{array}$ & 3 & 0 & Foodborne outbreak & CSPI,2011 \\
\hline Queso Fresco & $\begin{array}{l}\text { L } \\
. \text { monocytogenes }\end{array}$ & -- & -- & Food recalls & CDC,2013 \\
\hline Queso Fresco & S. enterica & 37 & n.a & Foodborne outbreak & CSPI,2011 \\
\hline Mozzarella & E. coli 0121 & -- & -- & Food recalls & Kleinman, 2013 \\
\hline Queso Fresco & $\begin{array}{l}L . \\
\text { monocytogenes }\end{array}$ & 17 & 8 & Foodborne outbreak & CDC,2015 \\
\hline Queso Fresco & $\begin{array}{l}\text { L. } \\
\text { monocytogenes }\end{array}$ & 8 & 1 & Foodborne outbreak & $\mathrm{CDC}, 2014 \mathrm{c}$ \\
\hline Queso Fresco & $\begin{array}{l}\text { L. } \\
\text { monocytogenes }\end{array}$ & 3 & 1 & Foodborne outbreak & FDA, 2015a \\
\hline Queso Fresco & S. aerous & -- & -- & Food recalls & FDA, 2015b \\
\hline
\end{tabular}


Salmonella, L. monocytogenes and E. coli O157:H7 are the most common pathogenic bacteria that cause foodborne illnesses in dairy products, including soft cheeses. According to the Center for Disease Control and Prevention (CDC), in 2011, Salmonella held the second place in the top five foodborne pathogens responsible for illness at $11 \%$, and the first place for causing hospitalization and death, with $35 \%$ and $28 \%$ respectively. At the same time, E. coli made into fifth position on the top five list, with $4 \%$ of cases resulting in hospitalization. Listeria monocytogenes held the third position of the top five pathogens causing death, with $19 \%$ (CDC, 2014a). Salmonella, E. coli O157, and Listeria monocytogenes were found to be the most common pathogens causing foodborne outbreak in cheeses, with 1128, 254, and 91 cases of outbreaks, respectively from 1990 to 2011(Center for Science in the Public Interest, 2012; Zottola, 1991).

\subsubsection{Characteristics of Microorganisms Found in Cheese}

\subsubsection{Listeria Monocytogenes}

Listeria monocytogenes is pertinent to the dairy industry, since it can be introduced into food processing plants due to its pervasive characteristics, such as enduring in hostile environments and wide distribution can eventually cause contamination of dairy products during the manufacturing and post-manufacturing. This pathogenic bacteria is broadly dispersed in the environment in material such as soil, water, animal feces, and sewage. Listeria monocytogenes is a gram-positive, facultative anaerobic, rod shape, non-spore forming bacteria. This pathogen has 13 serovar founded on cellular $\mathrm{O}$ and flagellar $\mathrm{H}$ antigen; the serovars frequently implicated in diseases are $4 b, 1 / 2 a$, and $1 / 2 b$ (Lorber, 2007). Listeria monocytogenes grows at refrigeration temperatures between $-0.4^{\circ} \mathrm{C}-45^{\circ} \mathrm{C}$; its optimal temperature range is $30-37^{\circ} \mathrm{C}$. Listeria monocytogenes is also acid-tolerant, surviving at a $\mathrm{pH}$ range of $4.1-9.4$, with an optimum $\mathrm{pH}$ of 7.0 (Jay, 1996). It grows in food within a 0.90 to 0.97 range of water activity (Aw), with an 
optimal Aw of 0.92 . It is salt resistant, capable of surviving up to $25 \%$ of salt concentration, with $10 \%$ as its optimum growth (Schirmer et al., 2014).

Listeria monocytogenes can cause mild infection in healthy individuals, albeit with low predominance. Contrary, in immunologically vulnerable individuals-pregnant women, newborns, elderly, and immune-compromised individuals - this pathogen can cause an invasive and severe infection and subsequently death. In the USA, 1651 cases of listeriosis by the ingestion of contaminated dairy and leafy greens products were reported in the 2009-2011 period; elderly comprised $58 \%$ of cases, immune-compromised individuals with $28 \%$, and $14 \%$ for pregnant women, and caused a high mortality rate of $21 \%$ as a result of foodborne illness. Immune-vulnerable individuals can develop meningitis, encephalitis, abortion due to intrauterine infections, febrile gastroenteritis, brain infection, endocarditis, or septicemia (Jordan, Leong, Álvarez Ordóñez, 2015; Silk, et al., 2013); through its diffusion across the placenta, and attacks on the central nervous system (Lorber, 2007). The virulence of L. monocytogenes is accomplished through several factors. This pathogen produces hemolysis of red blood cells by its enzyme called listeriolysin $\mathrm{O}$, causing its spread in the host, and it also invades human host cells without being phagocytized through internalin (Jay, Loessner \& Golden, 2005). Pathogenesis of this organism first occurs from the ingestion of contaminated food. The pathogen then travels to the intestine and crosses the mucosal barrier. Once in the blood stream, the pathogen multiplies, and it is able to spread to different host organs. The dose required to produce illness is unknown, however, $\geq 10^{3}$ cells of this pathogen might cause illness in unhealthy individuals (Jay, Loessner \& Golden, 2005; U.S FDA, 2012).

\subsubsection{Listeria Innocua}

Listeria innocua and L. monocytogenes are genetically closely related species and indeed were classified within the same species before 1981 (Friedly et al., 2008). These two bacteria share the same habitat; however, L. monocytogenes is considered to be a human and animal pathogen (Allerberger, 2003). Listeria innocua, similar to L. monocytogenes, is a gram-positive, 
facultative anaerobic, non-spore forming, nonpathogenic bacteria widely dispersed in the environment, and a member of the ten species of the genus Listeria (Liu, 2013).

In the food industry, L. innocua has been used as a surrogate, with the same or greater psychological characteristics as the pathogenic target organism providing safety without exposure to pathogenic bacteria. L. innocua is a fastidious organism that survives and grows in extremely harsh conditions, for example, high salt concentration, temperature, and $\mathrm{pH}$. Listeria innocua is serologically differentiated from $L$. monocytogenes due to the lack of $\beta$-hemolysis production on blood agar (Allerberger, 2003). In the present study, L. innocua will be studied in lieu of $L$. monocytogenes to prevent exposure to its pathogenicity.

\subsubsection{Salmonella}

Salmonella, part of the Enterobacteriacea family, is a gram-negative bacteria, broadly distributed in nature, with mammals being their main reservoir. Salmonella is characterized as being non-spore forming, motile and rod-shaped. Salmonella grows at temperatures between $5{ }^{\circ} \mathrm{C}$ to $47^{\circ} \mathrm{C}$, with $37^{\circ} \mathrm{C}$ being the optimum temperature, and at a $\mathrm{pH}$ from 4.5 to 5.50. Salmonella grows at a water activity (Aw) of 0.93 , although some strains can survive at a water activity (Aw) of 0.43 to 0.94 (Adams, 2014; Jay et. al. 2007). The genus of Salmonella has to two species, Salmonella enterica and Salmonella bongori. Each species includes multiple serovars. S. enterica has six subspecies: enterica, salamae, arizonae, diarizonae, houtenac, and indica (Ray \& Bhunia, 2008).

Food contaminated with only one cell of serotypes of the genus Salmonella can cause salmonellosis, with symptoms of nausea, vomiting, abdominal pain, headache, chills, and diarrhea accompanied by prostration, muscular weakness, fever, and lethargy. The incubation time of this pathogen is 6 to 48 hours after the ingestion of contaminated food, and acute symptoms can persist for 2-3 days depending on the dosage. This pathogen might cause chronic symptoms such as arthritis, and major complications, such as septicemia (U.S FDA, 2012; Ray \& Bhunia, 2008). 
Among cheese producers, Salmonella is an important concern due to its low infection dosage, and because of the history of the link between cheese products and Salmonella outbreaks. These outbreaks have been caused by contaminated raw milk, improper pasteurization, and inadequate sanitation equipment and handling practices by personnel (Fox, Guinee, and Cogan, 2000).

\subsubsection{Escherichia coli 0157:H7}

Escherichia coli are a gram negative, facultative anaerobe, non-spore forming, rod shape bacteria. Some strains are harmless and live in the natural microflora of the human and warm blooded animals' intestine. Some strains are pathogenic, causing foodborne illnesses. E. coli strains are categorized based on their virulence properties. Strains include: enterohemorrhagic $E$. coli (EHEC), enteropathogenic E. coli (EPEC), enteroinvasive E. coli (EIEC), and enterotoxigenic E. coli (ETEC), enteroinvasive E. coli (EIEC), diffusely adherent E. coli (DAEC) (Ray \& Bhunia, 2008).

Escherichia coli $\mathrm{O} 157: \mathrm{H} 7$ is a widely known foodborne pathogen; this strain is part of the enterohemorrorrahagic serogroup (EHEC) that produces shiga toxin. E. coli O157:H7 distinguished from other E. coli for its inability to ferment sorbitol (Adams, 2008).

Typical symptoms of infection by E. coli O157:H7 transmitted via contaminated food are abdominal pain, vomiting, and diarrhea. Hemolytic uremic syndrome (HUS) is a severe complication of the infection by this pathogen and can cause kidney failure. The incubation period of E. coli O157:H7 is about 1 to 10 days after ingestion, and the infective dosage is 10-100 cells (CDC, 2015). E. coli O157:H7 grows at a minimum water activity (Aw) of 0.95 , and a $\mathrm{pH}$ range from 4.0 to 7.5 . It also grows in temperatures ranging from $10^{\circ} \mathrm{C}$ to $45^{\circ} \mathrm{C}$; where its optimal growth is at $30^{\circ} \mathrm{C}$ to $42^{\circ} \mathrm{C}$ (Buchanan \& Doyle, 1997; Ray \& Bhunia, 2008; WHO, 2011). It is important to know the mechanism of survival of this pathogen since it has been the cause of outbreak and recalls in dairy products. 


\subsubsection{Psychrotrophs}

Psychrotrophs bacteria are a group of different bacteria, which includes gram positive and gram negative bacteria. Psychotropic bacteria grow at temperatures from $0{ }^{\circ} \mathrm{C}$ to $7^{\circ} \mathrm{C}$, and some species grow at temperatures higher than $43^{\circ} \mathrm{C}$ with optimum growth between $15^{\circ} \mathrm{C}$ to $20^{\circ} \mathrm{C}$. They also grow under a wide range of $\mathrm{pH}$ and water activity. These bacteria are abundant in the environment and can be found in water, soil, vegetation, and air. The most common genera of psychotropic bacteria found in dairy products are: Pseudomonas, Aeromonas, Serratia, Acinetobacter, Alcaligenes, Achromobacter, Enterobacter, Flavobacterium, Bacillus, Clostridium, Corynebacterium, Microbacterium, Micrococcus, Arthobacter, Streptococcus, Staphylococus and Lactobacillus. They are characterized by their ability to hydrolyze proteins and lipids. Some Psychotropic bacteria cause a reduction in yield and quality of cheese curd by affecting the regular growth of starter cultures, rancidity, off-flavors, undesirable texture, unappealing appearance, as well as affecting the shelf life of cheese products. These bacteria might cause diseases in immuno-suppressed individuals and suppress the activity of antibiotics (Ledenbach \& Marshall, 2010; Samaržija, Zamberlin, \& Pogačić, 2012 )

\subsubsection{Yeast and Molds}

Yeasts are eukaryotic organisms, carbohydrate fermenters, and unicellular fungi, while molds are multi-cellular fungi. Yeast cell sizes are 5 to $8 \mu \mathrm{m}$ in diameter and oval, elongated, elliptical, or spherical cell shaped. They are differentiated by their color (creamy, pink, etc.). Yeasts can grow anaerobically or aerobically, are heat-labile, can grow at different ranges of $\mathrm{pH}$ and temperatures, and in the presence of ethanol or sucrose. Yeast grow at a water activity (Aw) range from $0.60-0.88$. The most common genera of yeast that can cause spoilage in dairy products are Candida, Debaryomyces, Kluyveromyces (Fabospora), Rhodotorula, and Saccharomyces. Spoilage of dairy products with yeast causes defects of aroma, off- flavor, undesirable texture and appearance, and de-acidification of products (Roginski, 2014). 
Molds are unicellular fungi that require low water activity, an extensive range of $\mathrm{pH}$ and temperature to grow. Mold involved in the spoilage of dairy products are aerobic, grow at cool or freezing temperatures, require low water activity, and prefer high amounts of salt. The genera found in the spoilage of cheese are Alternaria, Cladosporium, Aspergillu, Eurotium, Fusarium, Mucor, and Penicillium. Cheese spoilage by mold causes off-flavors and off-odors due to their action in degrading the acids in dairy products. Ingestion of dairy products with mold can cause severe consequences in people with weak immune systems (Roginski, 2014).

\subsubsection{Coliforms}

Coliforms are aerobic and facultative anaerobic, non-spore forming, rod shaped, gram negative bacteria. Coliforms grow at low temperatures from -2 to $50^{\circ} \mathrm{C}$, and a pH range of 4.4 to 9.0. Enterobacteriaceae: Citrobacter, Enterobacter, Escherichia, and Klebsiella are the most common genera that represent coliforms. Their presence in food is negatively correlated with product quality meaning that food has been processed under unsanitary conditions. Spoilage by this microorganism affects cheese curds' coagulation by reducing the production of acid in starter cultures and produces gas in food products (Adams, 2008).

\subsubsection{Sources of Cheese Contamination}

Cheeses are ready to eat (RTE) products that do not require additional treatments before consumption. Microbial contamination of cheese occurs through different routes during cheese processing and post-processing. During cheese processing, milk, starter cultures, brine, packaging material, production environment, and utensils all carry contamination potential (Kousta et al., 2010). Raw milk can be contaminated by pathogenic bacteria through the udder of an infected cow (mastitis) or through fecal contamination. Staphylococcus aureus pathogen is a major cause of udder infections in cows, and up to $8 \log \mathrm{CFU} / \mathrm{ml}$ might pass in milk. L. monocytogenes, $E$. coli O157: H7 and Salmonella spp have also been the cause of udder infection in cows (Kousta et al., 2010; Sanaa, Poutrel, Menard, \& Serieys, 1993). Incidence of pathogens in milk is also 
influenced by farm size, number of animals on the farm, hygiene, farm management practices, geographical location, and season (Oliver, Jayarao, \& Almeida, 2005). Pathogenic bacteria can contaminate milk and, consequently, may spread throughout milking machines and installations. Production of cheeses with contaminated, raw or improperly pasteurized milk can potentially result in contaminated cheeses. Cheeses produced with raw milk require 60 days of aging prior to consumption; however, low levels of pathogenic bacteria in milk can survive in the manufacturing of cheese for more than 60 days of aging (D'Amico, Druart, \& Donnelly, 2010).

Although a few cases of contaminated dairy products through starter cultures have been reported; it is important to mention that starter cultures can be a source of cheese contamination due to insufficient hygienic preparation, preparation by disqualified personnel, or improper storage conditions of cultures (Irkin, 2010; Kousta et al., 2010). It has been reported that cheese starter cultures for soft Turkish cheese-within the pasta filata cheese family — contained a high level of microbial counts by total aerobic mesophilic bacteria, coliforms, Enterobacteriaceae, Staphylococci, psychrophilic bacteria, yeasts, and molds. Contamination of starter cultures can inactivate the activities of starters, as well as prevent starters from inhibiting the activity of potential pathogenic bacteria during the production of cheese (Irkin, 2010).

Another source of pathogenic contamination during cheese processing is through contaminated brines possibly due to environmental sources, such as improper manufacturing techniques (GMP). Listeria monocytogenes is salt tolerant and can survive in brine solutions and so can contaminate cheese products. Salmonella in brine solution has also been a cause of cheese contamination ( Irkin, 2010; Larson, Johnson, \& Nelson, 1999).

In addition, pathogenic bacteria can contaminate dairy products due to post-process recontamination, mainly due to cross contamination between raw ingredients and processed products, improper cleaning of equipment and processing plant, improper handling practices and improper sealing or defective packaging materials (Reij \& Den Aantrekker, 2004). Indonesian soft, fresh cheeses have been reported to be contaminated with E. coli and Salmonella due to 
inappropriate processing equipment and improper food handling practices by workers (Street \& Bogor, 2013).

Cheese can also be contaminated at any stage of its manufacture process through contact with the equipment (Reij \& Den Aantrekker, 2004). Pathogens can survive on the surfaces of equipment for long periods of time (up to years), causing post-process recontamination. $L$. monocytogenes has been well-documented as the cause of post-manufacturing contamination in fresh cheeses due to cross contamination with food and non-food contact surfaces, and staff attire (Rückerl et al., 2014). Listeria monocytogenes was also identified in three Latin-type cheese processing plant environments and their cheese products due to lack of adequate facilities and equipment, causing cross contamination of the final product (Kabuki, Kuaye, Wiedmann, \& Boor, 2004). Additionally, E. coli O157:H7 and Salmonella have been detected in the processing environment of dairy products, which includes drains, floors, and workers themselves (CagriMehmetoglu et al., 2011; Street \& Bogor, 2013). These pathogens can rapidly colonize different sites within the processing plants due to its ubiquitous distribution, and consequently penetrate and contaminate cheese during post-manufacturing.

Mozzarella and Queso Fresco are fresh, soft unripened cheeses with a high moisture content making them susceptible to spoilage and pathogenic bacteria. Thus, to reduce the possible risk of bacterial contamination of dairy products during the processing or post-processing environment, good manufacturing techniques are required to prevent the growth or survival of the bacteria in the case of pathogenic contamination.

\subsection{Salt}

\subsubsection{Role of Salt in Cheese}

The role of salt $(\mathrm{NaCl})$ in cheese production is multifaceted. Salt enhances flavor, acts as a preservative, and influences texture by contributing to enzymatic activities, such as the fermentation of sugars essential for the body and texture of cheese (Cruz et al., 2011). Salt also 
influences the firmness of cheese by decreasing and controlling the $\mathrm{pH}$ level of cheese by lowering the proteolysis activity and increasing the hydration of casein. It also has an effect on the meltability of cheeses as it improves its flowability and stretchability through its action of promoting moisture retention (Cruz et al., 2011; Pastorino, Hansen, \& McMahon, 2003). Salt improves cheese texture; for instance, unsalted Muenster cheese was injected with a solution of salt daily and kept at $4^{\circ} \mathrm{C}$ for 40 days. It was observed that following the first injections, the cheese's texture and adhesiveness were improved (Agarwal et al., 2011; Guinee, 2004; Pastorino, et al., 2003; Saint-Eve et al., 2009). Studies regarding salt function in cheese texture is debatable. Flowery et al. (2009) studied the microstructural and rheological properties of a lipoprotein model matrix, a scientific formulation that mimics hard-types of cheese, and they found that low sodium cheeses produced hardness and cohesiveness and lowered the adhesiveness of their matrix model. In this study, salt was not a contributor to the texture of the cheese.

Furthermore, salt also influences in the growth of microorganisms by reducing water activity and increasing the osmotic pressure in the aqueous phase of food. A low water activity and high osmotic pressure produces an interruption of the mass transfer through cell membranes, which causes ionic loss of bacteria thus preventing growth (Cruz et al., 2011). The microbial stability in cheese is carried by the action of salt with other intrinsic properties, such as water activity, $\mathrm{pH}$, and lactic acid bacteria, which act in synergy to prevent bacterial proliferation.

The function of salt is still in contention; therefore, more investigation is required to conclude that salt concentration might not guarantee or predict the control of pathogenic bacteria in cheese.

\subsection{Pathogen Growth and Intrinsic Factors in Cheese}

The growth and survival rate of pathogenic bacteria on cheeses has been well documented. Shrestha et al. (2011) studied the fate of L. monocytogenes in cheddar cheese with low $(0.7 \%)$ compared to regular $(1.8 \%)$ salt at high $(\geq 5.5)$ and low $\mathrm{pH}(\leq 5.4)$. These cheeses at 
four different concentrations of salt and $\mathrm{pH}$ were assayed and innoculated with $3.5 \mathrm{log} \mathrm{CFU} / \mathrm{g}$ of L. monocytogenes and then stored at 4,10 , and $21^{\circ} \mathrm{C}$ for up to 30 and 90 days. The four treatments included: $0.7 \% \mathrm{NaCl}$ with $5.1 \mathrm{pH}, 0.7 \% \mathrm{NaCl}$ with $5.5 \mathrm{pH}, 1.8 \% \mathrm{NaCl}$ with $5.8 \mathrm{pH}$ and $1.8 \% \mathrm{NaCl}$ with $5.3 \mathrm{pH}$. Listeria monocytogenes decreased by $0.9,0.54,0.69,1.48 \log$ CFU/g for each treated cheese, respectively. They concluded that in cheddar cheeses with different salt concentrations, L. monocytogenes gradually decreased over time in cheeses with a pH range between 5.3 to 6.9 and does not support growth in cheeses within a 5.1 to $5.5 \mathrm{pH}$ range. Salt in cheddar cheese was not a control agent for the growth of pathogens; however, safety practices should still put this into practice to prevent contamination of cheeses. The growth and survival of pathogenic bacteria, particularly, L. monocytogenes might have been affected by other intrinsic factors within the cheese matrix, such as lactic acid bacteria, which is part of the natural microbiota of cheese.

E. coli $\mathrm{O} 157: \mathrm{H} 7$ is another fastidious pathogen that can survive after contamination during the processing of cheese. Mohammadi et al. (2009) investigated the survival of E. coli O157:H7 in a salt brine concentration during the production and storage of Iranian white cheese. Four different types of cheeses were made with pasteurized milk then inoculated with $3 \log$ CFU/g of E. coli $\mathrm{O} 157: \mathrm{H} 7$ and different concentrations of salt in brine (6\% and 8\%). Each cheese was prepared with or without a starter culture. The population of E. coli $\mathrm{O} 157: \mathrm{H} 7$ in all the cheeses rose by $3 \log$ CFU/g in the first seven hours of manufacturing. However, by the end of the ripening step, the cheese prepared with a starter culture had a bacterial population of $2 \log$ CFU/g lower than the cheese made without the starter, regardless of brine concentration. During storage for 60 days at $4^{\circ} \mathrm{C}$, pathogenic bacteria steadily diminished for cheeses made with starter culture, but remained almost the same for cheeses made without starter culture, again independent of the brine concentration. This study suggests that salt does not affect the growth of bacteria, whereas starter cultures might be involved in the survival/growth of E.coli O157:H7. Conversely, Spano et al. (2003) tested the survival of E. coli during the manufacture, ripening, and storage of 
mozzarella cheese. They used unpasteurized milk, two strains of E. coli (VTECI, VTEC2), and two different stretching temperatures $\left(70^{\circ} \mathrm{C}\right.$ and $\left.80^{\circ} \mathrm{C}\right)$ for each strain of bacteria during the processing of the cheese. They found that stretching the curd at $80^{\circ} \mathrm{C}$ for 5 minutes in hot water inactivated the population of E.coli. Contrary, stretching the curd at $70^{\circ} \mathrm{C}$ for 5 minutes did not eliminate the bacterial population; it only decreased the bacterial population by $1 \log \mathrm{CFU} / \mathrm{g}$. However, the population of $E$. coli was later reduced by $2 \log \mathrm{CFU} / \mathrm{g}$ during the brining and storage steps of the manufacturing process. Although E. coli was undetectable for cheeses stretched at $70^{\circ} \mathrm{C}$ after seven days of storage, stretching the curd of mozzarella cheeses at $80^{\circ} \mathrm{C}$ would make a bigger impact in microbial inhibition. Since pathogens cannot survive stretching temperatures, risk of cheese contamination might be caused by post-manufacturing.

Additionally, Salmonella survival and growth in cheese has been studied in the dairy industry. Alemdar and Ağaoğlu (2010) evaluated the survival of Salmonella Thyphimurium in Turkish herby cheese after milk was inoculated $\left(10^{3}\right.$ and $\left.10^{5} \mathrm{CFU} / \mathrm{mL}\right)$ and then stored the cheese in different kinds of salting processes (salting in brine or surface). Salmonella was not detected in surface salting cheeses. However, about $3 \log \mathrm{CFU} / \mathrm{g}$ less bacterial population was seen for brine cheeses after 90 days of ripening, despite the concentration of salt in cheeses brined (9.2-9.8\%) being about 5 times higher than the surface-salted cheeses (4.33\%). This finding indicated that the inhibition of pathogens in Turkish cheese is due to other formulation factors, such as the effect of the addition of herbs into the cheese, processing techniques, and storage, not just salt content.

Although pathogenic bacteria can be introduced in cheese during its processing, intrinsic factors of cheese exist that disable the survival and growth of pathogenic bacteria. Intrinsic factors refers to the characteristics of the cheese, such as $\mathrm{pH}$ and acidity, water activity, moisture content, starter cultures, redox potential, salt, and nutrient content (Adams, 2014). Pathogenic bacteria, particularly L. monocytogenes in cheddar cheese, can be progressively inactived by a combination of intrinsic factors (Shrestha et al., 2011). This finding might be applied to other types of bacteria and cheese. Traditionally, salt content in cheese has been considered as the 
leading intrinsic factor that diminishes the risk of microbial growth, causing a perception that low sodium cheeses might be more susceptible to microbial growth. However, the studies above suggest that salt does not have a dominant effect on the survival and growth of pathogenic bacteria, while the cheese matrix as whole might be involved in inhibition of bacteria. Cheeses with reduced and regular sodium might be equally safe.

\section{$\underline{\text { 1.6.1 Control Measures }}$}

To prevent or minimize the prevalence of spoilage and pathogenic bacteria in dairy products, several effective methods can be employed. These methods are multiple barriers/hurdles, antimicrobial agents, and heat treatment.

\subsubsection{Multiple Barriers/Hurdles}

Multiple barriers are generally used to control microbial growth. This technique includes the use of several factors at sub-inhibitory concentration; multiple barriers act synergistically to control the growth and survival of spoilage and pathogenic bacteria. Some examples of multiple barriers include: Physicochemical factors — antimicrobial agents, and physical elements - heat treatment (Kumari, 2014; Marth, 1998).

\subsubsection{Antimicrobial Agents}

Dairy products can be formulated with antibacterial and antifungal ingredients. Organic acids are used as a preservative agent in the food industry because they are generally recognized as safe compounds (GRAS). Lactic acid is within this category and acts as antimicrobial by modifying the homeostasis of bacterial cells, causing membrane interruption, inhibiting metabolic reaction, and leading to ultimate microbial death (Marth, 1998). Essential oils were used as antimicrobial agents. Thymus, cinnamon, oragamus, and pimiento oils have antimicrobial activity against Escherichia coli O157:H7, L. monocytogenes, Salmonella typhimurium, and Staphylococcus aureus with a minimum inhibitory concentration of $0.1 \%$ and a maximal tolerate 
concentration of $0.025 \%$. These oils were derived from different plant species within those common names (Oussalah, Caillet, Saucier, \& Lacroix, 2007). Sorbate, propionate, and benzoate have also been used as antibacterial and antifungal agents (Kumari, 2014).

\subsubsection{Heat Treatment}

Heat treatment is another typical method used in the food industry to reduce the growth of a bacterial population that is strictly dependent on temperature and time. Heat treatment generally inactivates vegetative cells, but not spores (Kumari, 2014). After the use of this treatment, samples can be contaminated with bacteria; therefore, safety hygienic techniques need to be applied. Pasteurization is an example of heat treatment. Particularly for cheeses, heat treatment is mainly applied at the beginning of the cheese-making process to destroy microorganisms in raw milk (Kumari, 2014). However, this technology is not feasible for all cheese products. Thus, alternative methods have been developed to replace those methods.

\subsubsection{Alternatives Preservative Treatments}

New emerging technologies have been developed in response to consumer demands for fresh, more nutritional, and safer food products, without the application of heat. Some examples of this technology are: Pulsed UV-light treatment, High Pressure Processing (HPP), and Supercritical Fluid Extraction (SFE).

\subsubsection{High Pressure Processing (HPP)}

High pressure processing (HPP), also called high hydrostatic pressure (HHP) or Ultrahigh pressure (UHP) is cold pasteurization technology. Pressure is utilized to preserve food. Because pressure is evenly distributed in the product, the food characteristics are not modified. HPP causes minimal effects on texture, nutrient content, odor, and taste of food product. HPP pressures ranges up to $900 \mathrm{MPa}$ or $9000 \mathrm{~atm}$, and temperature ranges from $0^{\circ} \mathrm{C}$ to above $100^{\circ} \mathrm{C}$. Generally, products are exposed to pressure from millisecond pulses to 1200 s. HPP acts as a preservative by causing morphological and structural modifications in the cell. HPP also causes 
alterations in the gene regulation of the cell, leakage of intracellular fluid, and disruption of the cell membrane mainly by alteration of cell permeability. Consequently, cell death occurs because of injuries to different parts of the cell (Rendueles et al., 2011).

HPP technology has already been used in the dairy industry to minimize microbial content without affecting cheese characteristics. HPP at 300 and $400 \mathrm{MPa}$ for 5 min at $6{ }^{\circ} \mathrm{C}$ was applied to starter-free fresh cheese $\left(\mathrm{pH}\right.$ 6.72). Then, cheeses were stored at $4^{\circ} \mathrm{C}$ and $8^{\circ} \mathrm{C}$ for 21 days. Cheeses treated at a higher pressure (400 MPa) had a reduction of psychrotrophic bacteria, Enterobacteriaceae, yeast, and mold. Treated cheeses had a firmer texture and were less watery, also, neither color aroma nor flavor were changed (Evert-Arriagada, Hernández-Herrero, Juan, Guamis, \& Trujillo, 2012).

Although HPP is an innovative technology that increases the shelf-life of food products with a minimal effect on the product, the HPP process is expensive, some bacteria cannot be completed eliminated, and spores are not inactivated (Rendueles et al., 2011).

\subsubsection{Pulsed UV-Light Treatment}

Pulsed UV-light is an emerging treatment that utilizes ultraviolet and infrared radiation.

Radiation is delivered in small pulses through a xenon gas lamp. Pulsed UV-light treatment dissipates intense small pulses from deep UV to infrared in a short millisecond time frame generating a broad wavelength from 100 to $1100 \mathrm{~nm}$. The wide range of wavelengths has an effect on the inactivation of spoilage and pathogenic bacteria. The DNA and RNA of microorganisms is altered, causing cell death. The cell can be collapsed by the absorption of heat provoking an internal imbalance, a reduction of cytoplasm, and injury of the cell wall (Can, Demirci, Puri, \& Gourama, 2014; Keklik \& Demirci, 2009; Krishnamurthy, Demirci, \& Irudayaraj, 2007). Can et al., 2014 investigated the inactivation of $P$. roqueforti and $L$. monocytogenes in packaged and unpackaged hard cheeses by applying pulsed UV light. $P$. roqueforti decreased by 1.25 and $1.32 \mathrm{logs}$, after samples were exposed at a distance of $5 \mathrm{~cm}$ with 40s on packaged and unpackaged hard cheeses, respectively. Population of L. monocytogenes 
declined $3.07 \operatorname{logs}$ on packaged cheeses treated at a distance of $8 \mathrm{~cm}$ with $50 \mathrm{~s}$, and 3.08 logs on unpackaged cheeses exposed at a distance of $5 \mathrm{~cm}$ with 40s. Pulsed UV light can be used as a post-processing tool to prevent contamination of cheeses. However, this system has drawbacks, as pulsed UV-light cannot penetrate evenly or deeply into a food product, and it is color dependant — opaque and transparent food absorb the light differently (Can et al., 2014).

\subsubsection{Supercritical Fluid Extraction (SFE)}

A supercritical state of a particular substance is when its temperature and pressure are higher or equal to its critical values. Despite the higher pressure, at supercritical temperature, the liquid phase does not occur. Critical pressure is the pressure that produces the gas to convert liquid at critical temperature; critical density is the density at critical point. Supercritical fluid extraction is defined as the separation of a particular substance from a product and is combined with supercritical fluid to form a mobile phase. The mobile phase utilizes pressure and temperature at, or higher than, the critical point to improve the mobile phase solvating power, whereby at the critical point, gas and liquid phases merge to form a supercritical phase (Fig. 1) (Palmer \& Ting, 1995). A change in pressure or temperature enhances the control of the fluid density, diffusivity, dielectric constant, and viscosity. During the supercritical state, no phase boundaries, such as a liquid or gas phases, are overlapped as a result of exceeding the critical temperature and pressure. A supercritical fluid is also characterized by a high diffusion rate, reduced viscosity and surface tension. These characteristics help to improve its mass transfer, effusion of the fluid through solids (Palmer \& Ting, 1995; Sihvonen, Järvenpää, Hietaniemi, \& Huopalahti, 1999).

During the process of supercritical fluid extraction, first, a low pressure causes a rise in the solute

vapor. Pressure is inadequate to fully compensate for the loss of solvent power causing a reduction in solvent density. Then, temperature and pressure rise, causing an increase in solute 
vapor pressure, and in compensation for the reduction in solvent density causes a higher solubility (Palmer \& Ting, 1995).

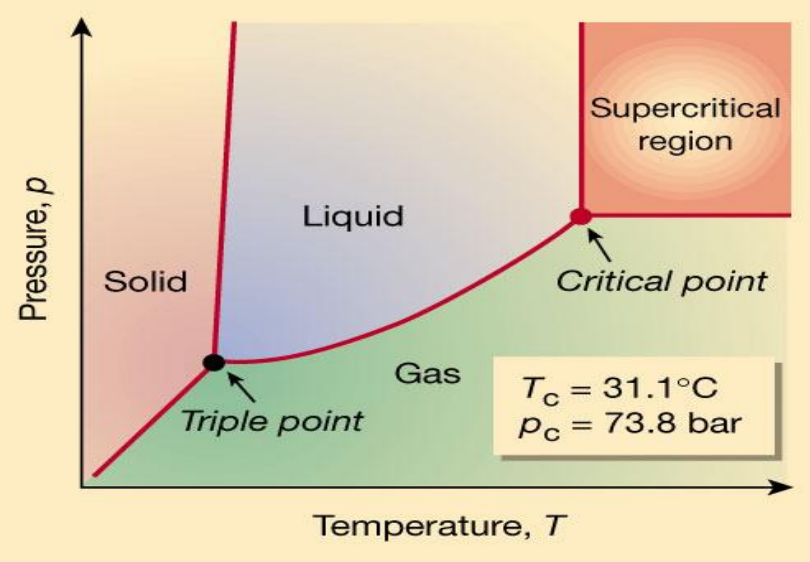

Figure 1-1: SFE-CO2 Pressure-Temperature Phase Diagram (Leitner, 2000)

A simple SFE machine consists of an extraction tank equipped with temperature controllers and pressure valves to control the correct extraction. It also has a pump that controls circulating the fluid in the system and helps transfer the solubilized components to the separator. In the separator, the solubility of the fluid is lowered by reducing the pressure or raising the temperature. Finally, the end product is collected through a valve placed in the lower part of the separator (Fig. 2) (Sairam, Ghosh, Jena, Rao, \& Banji, 2012; Sihvonen et al., 1999).

During the supercritical fluid extraction (SFE), the surface area, sample size, moisture content, and interaction of the product with the fluid are important parameters that can affect the solubility and the results of the supercritical fluid (Sairam, Ghosh, Jena, Rao, \& Banji, 2012) (Fig.1). Carbon dioxide, nitrogen oxide, ammonia, ethane, propane, ethylene, and Freon 13 are typical gases used for critical fluid extraction (Rozzi \& Singh, 2002). Carbon dioxide $\left(\mathrm{CO}_{2}\right)$ is most commonly used in the food industry as it is generally recognized as safe (GRAS), ecofriendly, inexpensive, non-flammable, non-toxic, as well as for its high diffusion, solvent strength, and solvent-free characteristics. Carbon dioxide is also inert and acts as a solvent for 
certain solutes. It is vaporous at room temperatures, which facilitates the analytical recoveries. It also can be used at low and safe temperatures and pressures; it is recyclable, available in high purity, and does not leave residues (Herrero et. al, 2010). The critical conditions of carbon dioxide are at $31.06{ }^{\circ} \mathrm{C}$ and $7.386 \mathrm{MPa}$ (Rozzi \& Singh, 2002).

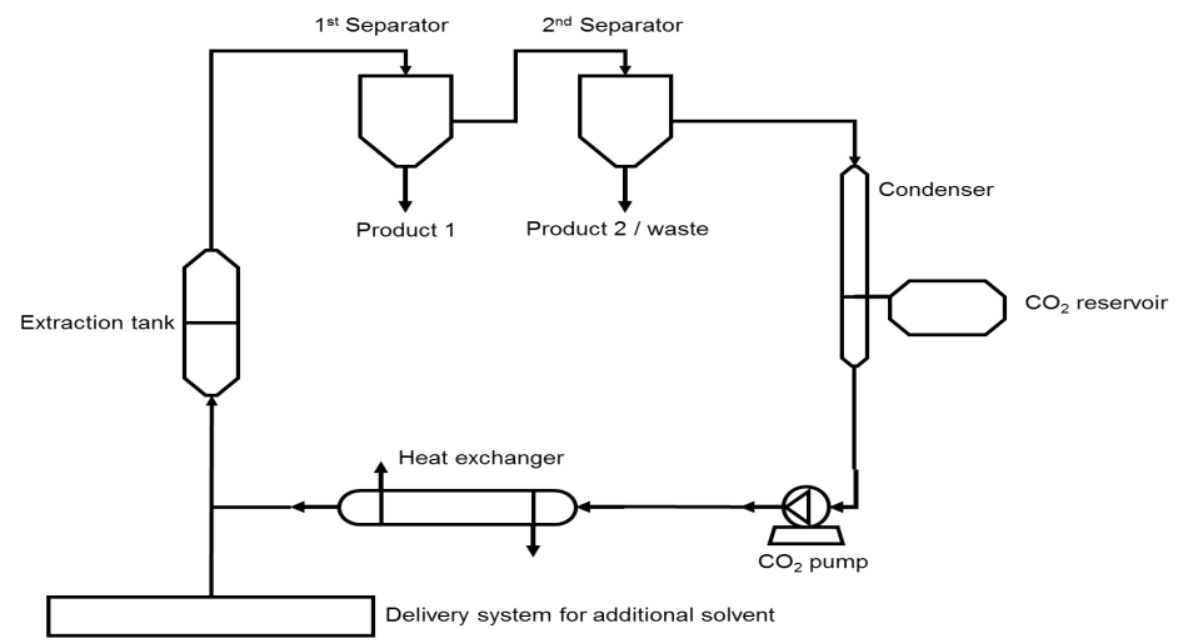

Figure 1-2: Flow diagram of a supercritical fluid extraction system

(Adapted from Sihvonen, Järvenpää, Hietaniemi, \& Huopalahti, 1999)

Supercritical fluid extraction (SFE) with $\mathrm{CO}_{2}$ has been utilized for diverse applications. In the context of microbiology, SFE affects the inactivation of microorganisms. Inactivation with SFE is associated with pressure, temperature, and exposure time. SFE $\mathrm{CO}_{2}$ inactivates microorganisms by its penetration into the product. Once $\mathrm{CO}_{2}$ is permeated into a product, it disrupts the biological systems of the cell wall of the microorganism, causing lethal effects. SFE with $\mathrm{CO}_{2}$ may also remove the lipid compound of the cell and cause a leakage of cytoplasm, inactivating the action of the microorganism (Hong \& Pyun, 1999). The inactivation of microorganisms with SFE- $\mathrm{CO}_{2}$ can result in cellular death because of damage to the cellular envelopes. Carbon dioxide accumulates in the lipid phase, provoking higher activities of fluidity and permeability of the membrane, resulting in an order loss of the lipid chain. Fluidity of 
liposomes causes a modification of proteins, inactivating its function, as well as causing a modification in membrane enzymatic activities.

Furthermore, diffusion of $\mathrm{CO}_{2}$ into a product/organism also causes intracellular electrolyte imbalance, resulting in a removal of vital components due to the uncontrollable release of intracellular ions, proton permeability, and interruptions in glycolysis (Hong \& Pyun, 1999; Spilimbergo, Mantoan, Quaranta, \& Mea, 2009; Werner \& Hotchkiss, 2006). A sourdough yeast strain, S. cerevisiae, has shown inactivation after supercritical $\mathrm{CO}_{2}$ pasteurization at 100 bar and $36^{\circ} \mathrm{C}$ through cell analysis with a spectrometer. It was seen that yeast cellular injury was a consequence of irreversible cellular envelope injury due to the disruption of lipid structures and proteins of the cell membrane due to the accumulation of $\mathrm{CO}_{2}$. Carbon dioxide also permeabilized in the phospholipid bilayer of the cell membrane, finally causing cell death. Carbon dioxide is easily dispersed into the bacterial cell and causes a reduction of the intracellular $\mathrm{pH}$, resulting in a cellular collapse (Garcia-Gonzalez et al., 2009). Cellular collapse by SFE with $\mathrm{CO}_{2}$ causes breakdown due to carboxylation and decarboxylation reactions within the cells, producing a loss of ATP and net energy expenditure (Hotchkiss, Werner, \& Lee, 2006). Hong and Pyun (1999) exposed $8 \log \mathrm{CFU} / \mathrm{mL}$ of Lactobacillus plantarum to supercritical pressure $\left(80 \mathrm{~kg} / \mathrm{cm}^{2}\right)$ and temperature of $40^{\circ} \mathrm{C}$ for up to 150 minutes as well as non-supercritical and temperatures pressures. Cells of L. plantarum were also re-suspended in different $\mathrm{pH}$ mediums and buffers, which included MRS broth ( $\mathrm{pH} 4.5$ and 8.0), $0.1 \mathrm{M}$ acetate ( $\mathrm{pH} 4.5), 0.1 \mathrm{M}$ phosphate buffer ( $\mathrm{pH}$ 7.0), and sterile distilled water ( $\mathrm{pH}$ 6.0). At supercritical conditions--pressure and temperatureexposure to $5 \log \mathrm{CFU} / \mathrm{mL}$ reduced levels in less than 50 minutes, while non-supercritical parameters took a longer inactivation time of $150 \mathrm{~min}$. Cells re-suspended in acidic buffers (4.5 $\mathrm{pH})$ had the shortest inactivation time (25 $\mathrm{min})$, except for MRS broth (35 min) compared to alkaline mediums (60 $\mathrm{min})$. In this experiment, bacterial inactivation depended on pressure, temperature, exposure time, $\mathrm{pH}$, and the suspension media. 
Moreover, the effect of supercritical $\mathrm{CO}_{2}$ has also been applied to different foods to reduce bacterial contamination (Table1-4). For instance, bacterial reduction in milk was analyzed by using a continuous flow system, which used different $\mathrm{CO}_{2}$ concentrations, $-0,66$, and 132 $\mathrm{g} / \mathrm{kg}$ - aged raw skim milk with high concentrations of native psychrotrophic bacteria $(6 \log$ $\mathrm{CFU} / \mathrm{mL}$ ), and raw milk inoculated with 6-7 $\log \mathrm{CFU} / \mathrm{mL}$ of Pseudomonas fluorescens. For raw milk with a high concentration of psychotropic bacteria and inoculated with $P$. fluorescence, there was a significant decrement of bacteria under all tested conditions compared with the control, in which the highest reduction-5.35 and $5.02 \log \mathrm{CFU} / \mathrm{mL}$ - occurred under a $\mathrm{CO}_{2}$ concentration of $132 \mathrm{~g} / \mathrm{kg}$ and $20.7 \mathrm{MPa}$ pressure. In a continuous flow system apparatus, a higher concentration of $\mathrm{CO}_{2}$ with high temperature and pressure caused a significant bacterial reduction due to increased diffusion of $\mathrm{CO}_{2}$ into bacterial cells (Werner \& Hotchkiss, 2006).

The application of SFE- $\mathrm{CO}_{2}$ to inactivate microorganisms depends upon initial microbial load, since higher microbial concentrations need a longer exposure. A high bacterial concentration might create a protective layer in the aggregate, or clusters may form at minimal exposure time to counteract the bactericidal effects of $\mathrm{CO}_{2}$. Dry cured ham contaminated with $L$. monocytogenes was treated with $\mathrm{SFE}-\mathrm{CO}_{2}$. Total inactivation of ham with an inoculum of $L$. monocytogenes $\left(7 \log \mathrm{CFU} / \mathrm{g}\right.$ ) occurred after 30 minutes when SFE at $12 \mathrm{MPa}$ for $45^{\circ} \mathrm{C}$ was tested . In contrast, in a lower inoculated ham (3 log CFU/g), total inactivation occurred after 5 minutes (Ferrentino, Balzan, \& Spilimbergo, 2013). Sánchez-Macías et al. (2003), also treated gouda and majorero cheese with SFE using $1,000 \mathrm{~g}$ of $\mathrm{CO}_{2}$ at $35^{\circ} \mathrm{C}$ and 4 different pressures 10 , 20, 30 and $40 \times 10^{6} \mathrm{~Pa}$ for $50 \mathrm{~min}$. Gouda cheese had an initial population of $6.15 \mathrm{log} \mathrm{CFU} / \mathrm{g}$ for aerobic bacteria and $5.53 \log$ for lactococci. The initial total aerobic bacteria, lactococci, and lactobacilli were 5.38, 9.28, and $8.70 \log \mathrm{CFU} / \mathrm{g}$ in majorero cheese. After SFE treatment, approximately $2.8 \log \mathrm{CFU} / \mathrm{g}$ reductions of aerobic and lactococci bacteria in Gouda cheese at 10 $\mathrm{x} 10^{6} \mathrm{~Pa}$ occurred. However, on majorero cheese, the aerobic bacteria population saw the greatest reduction with $2.72 \log \mathrm{CFU} / \mathrm{g}$ at 30 and $40 \times 10^{6} \mathrm{~Pa}$ for lactococci and lactobacilli bacteria with 
4.31 and $5 \log$ CFU/g reduction, respectively. The fat content of cheeses was also reduced by 48 57\%, and no changes in the protein were seen (Sánchez-Macías, et al., 2013).

Additionally, Yuk et al. (2010) studied the action of a supercritical $\mathrm{CO}_{2}$ on Escherichia coli $\mathrm{K} 12$ in apple cider. Apple cider was inoculated with $7 \log \mathrm{CFU} / \mathrm{mL}$ of E. coli, and after 30 minutes, the cider was treated with to supercritical $\mathrm{CO}_{2}$. The parameters used were at a pressure of 7.6 MPa, 34, 38, and $42^{\circ} \mathrm{C}$ temperature, and a $\mathrm{CO}_{2}$ concentration of $0,3,5,8$, and $10 \%$ for 20 minutes. The greatest reduction was achieved at $8 \% \mathrm{CO}_{2}$ and $42{ }^{\circ} \mathrm{C}(7.31 \log \mathrm{CFU} / \mathrm{mL})$, followed by $6.03 \log$ reduction at $8 \%$ and $38{ }^{\circ} \mathrm{C}$. It was concluded that supercritical $\mathrm{CO}_{2}$ can be applied in juice to reduce bacterial organisms as recommended by the FDA (5 log CFU). This study demonstrated that for the reduction of microbial population in juice, supercritical $\mathrm{CO}_{2}$ was dependant on concentrations of $\mathrm{CO}_{2}$ and temperatures.

Supercritical $\mathrm{CO}_{2}$ has also been effectively used as an antimicrobial on alfalfa seeds inoculated with E.coli $\mathrm{k} 12\left(10^{4} \mathrm{log} \mathrm{CFU} / \mathrm{g}\right)$. Alfalfa seeds were exposed to supercritical $\mathrm{CO}_{2}$ conditions, for 15,30 , and $60 \mathrm{~min}$ at 2000,3000 , and 4000 psi at $50^{\circ} \mathrm{C}$. Samples below 4000 psi for $60 \mathrm{~min}$ showed to be the only effective parameter against aerobic bacteria by reaching an inactivation rate of $85.6 \%$. However, E. coli $\mathrm{K} 12$ was reduced at each pressure tested when exposed for 15 minutes with reductions of $26.6,68.1$, and $81.3 \%$, respectively. With exposure at a higher time and pressure, a significantly greater effect was seen with a reduction rate of $92.8 \%$ 4000 psi for 60 minutes. Germination rate was unaffected between treated samples and no difference was seen between treated and untreated seeds (Mazzon et al., 2001).

Furthermore, $\mathrm{CO}_{2}$ has also been used in foods with low moisture content. For instance powdered infant formula inoculated with Cronobacter spp. $\left(10^{6}\right.$ to $\left.10^{7} \mathrm{CFU} / \mathrm{g}\right)$ samples were exposed under supercritical $\mathrm{CO}_{2}$ treatment. The conditions used were 15, 20, and $25 \mathrm{MPa}$ of pressure, 63, 68, and $73^{\circ} \mathrm{C}$; for 10,20 , and $30 \mathrm{~min}$. Powdered infant formula treated with supercritical $\mathrm{CO}_{2}$ at $15 \mathrm{MPa}$ at $63^{\circ} \mathrm{C}$ showed no difference between the times used, but the highest reduction seen was at about $1.6 \log \mathrm{CFU} / \mathrm{g}$ at 30 minutes, whereas at $68^{\circ} \mathrm{C}$, there was a 
reduction of $1.54 \log \mathrm{CFU} / \mathrm{g}$ for $10 \mathrm{~min}$. At $73^{\circ} \mathrm{C}$, a reduction of more than $2 \mathrm{log} \mathrm{CFU} / \mathrm{g}$ was observed at $10 \mathrm{~min}$, and a significant reduction after 30 minutes occurred with the population of Cronobacter spp. being undetectable. Supercritical $\mathrm{CO}_{2}$ under $20 \mathrm{MPa}$ at $63^{\circ} \mathrm{C}$ for 10 minutes had a reduction of $1.61 \log _{10} \mathrm{CFU} / \mathrm{g}$, in the same conditions, but did not differ for 20 and/or 30 minutes of exposure. However, samples under $20 \mathrm{MPa}$ at $68^{\circ} \mathrm{C}$ had a significance difference at an exposure time of 30 minutes with a reduction of $3.99 \log \mathrm{CFU} / \mathrm{g}$, and the highest reduction occurred at $73^{\circ} \mathrm{C}$ under $30 \mathrm{~min}$ as the bacterial load was under detection limit. When $25 \mathrm{MPa}$ was assayed at $63^{\circ} \mathrm{C}$, a significant reduction of $2.50 \log \mathrm{CFU} / \mathrm{g}$ for 30 minutes was accomplished. At same time at $68^{\circ} \mathrm{C}$, the greatest reduction was at 30 minutes, with a similar reduction at a pressure of $20 \mathrm{MPa}(3.99 \log \mathrm{CFU} / \mathrm{g})$; for $73^{\circ} \mathrm{C}$ at 20 and 30 minutes, bacteria was reduced to below the detection limit. The quality of Powdered Infant Formula was also not affected since the water activity, $\mathrm{pH}$, and color of treated samples were not different from untreated samples. The lethal effect of supercritical $\mathrm{CO}_{2}$ on powdered infant milk was reinforced by the application of high temperature, pressure, and time (Kim et al., 2010).

In meat products, supercritical $\mathrm{CO}_{2}$ has been applied as an antimicrobial treatment. Bae et al. (2011) studied the action of supercritical carbon dioxide as a decontaminating agent on ground pork. Ground pork was inoculated with mesophilic bacteria, L. monocytogenes, Salmonella Typhimurium, and mesophilic bacteria at a concentration of $7 \log \mathrm{CFU} / \mathrm{g}$, and then exposed at pressure of $100,120,140 \mathrm{bar}, 40,45^{\circ} \mathrm{C}$, for $20,30,40 \mathrm{~min}$. For samples contaminated with mesophilic bacteria, effectiveness of the treatment was seen at 140 bar at $45^{\circ} \mathrm{C}$ for 40 minutes, with a mesophilic reduction of $1.66 \mathrm{log} \mathrm{CFU} / \mathrm{g}$. For the pathogenic bacteria tested, the same significant conditions had the greatest reduction, with L. monocytogenes at $2.42 \mathrm{log} \mathrm{CFU} / \mathrm{g}$, and Salmonella Typhimurium at $2.21 \mathrm{log}$ CFU/g. Once again, this study determinate that pressure, temperature, and time enhanced bacterial inactivation rate by supercritical $\mathrm{CO}_{2}$, and $L$. monocytogenes was more vulnerable at this non-thermal treatment than the other bacteria tested. 
Additionally, marinated pork products, such as soy sauce and hot pepper paste marinades were analyzed to evaluate the action of supercritical $\mathrm{CO}_{2}$ against E.coli, L. monocytogenes, Salmonella Typhimurium, and E. coli O157:H7. Products were inoculated with about $6 \log$ $\mathrm{CFU} / \mathrm{ml}$ of each pathogenic bacteria and treated at the following conditions: 10,12 , or $14 \mathrm{MPa}$, 40 or $45{ }^{\circ} \mathrm{C}$ for 20,30 , or $40 \mathrm{~min}$. On samples of soy sauce marinated pork, at an exposure time of 20 and 30 minutes, the E. coli population was decreased at every pressure and temperature, excluding $10 \mathrm{MPa}$ and $40{ }^{\circ} \mathrm{C}$ and at $12 \mathrm{MPa}$ and $40^{\circ} \mathrm{C}$ for 20 minutes. It was reported that in soy sauce, the reduction of $E$. coli was effective at $14 \mathrm{MPa}$ and $45^{\circ} \mathrm{C}$ for 20,30 , and $40 \mathrm{~min}$, with 4.72, 4.48, and $4.32 \log \mathrm{CFU} / \mathrm{cm}^{2}$, respectively. L. monocytogenes in soy sauce marinated pork had a higher decrease at $45^{\circ} \mathrm{C}$ for 20 minutes. Conversely, Salmonella Typhimurium in soy sauce was significant at $14 \mathrm{MPa}, 45^{\circ} \mathrm{C}$ for 40 minutes with an observed reduction load of $3.47 \log$ $\mathrm{CFU} / \mathrm{cm}^{2}$, whereas a bacterial load decrement of $2.75 \log \mathrm{CFU} / \mathrm{cm}^{2}$ was observed for soy sauce inoculated with E. coli O157:H7. For hot pepper paste products, reductions occurred only under $45 \mathrm{MPa}$ and $40^{\circ} \mathrm{C}$, with the exception of $10 \mathrm{MPa}$. Reduction of bacteria under $14 \mathrm{MPa}, 45^{\circ} \mathrm{C}$ for 40 min was reported to be the most significant; E. coli had a reduction of $2.12 \log \mathrm{CFU} / \mathrm{cm}^{2}, L$. monocytogenes of $2.64 \log \mathrm{CFU} / \mathrm{cm}^{2}$, Salmonella Typhimurium of $2.72 \log \mathrm{CFU} / \mathrm{cm}^{2}$, and E. coliO157:H7 of $2.17 \log \mathrm{CFU} / \mathrm{cm}^{2}$. In contaminated pork marinated in soy sauce, E. coli had a significant reduction at 40 minutes, but not for $12 \mathrm{MPa}, 45^{\circ} \mathrm{C}$ and $14 \mathrm{MPa}$ and $45^{\circ} \mathrm{C}$. A reduction of $2.4 \log \mathrm{CFU} / \mathrm{cm}^{2}$ of E. coli was seen under $12 \mathrm{MPa}, 40^{\circ} \mathrm{C}$ for $40 \mathrm{~min}$. Listeria monocytogenes decreased significantly $\left(2.5 \log \mathrm{CFU} / \mathrm{cm}^{2}\right)$ at $14 \mathrm{MPa}, 45^{\circ} \mathrm{C}, 40 \mathrm{~min}$, while Salmonella Typhimurium and E. coli $\mathrm{O} 157: \mathrm{H} 7$ decreased 2.4 and $2.3 \log \mathrm{CFU} / \mathrm{cm}^{2}$, respectively under the same conditions.

SFE- $\mathrm{CO}_{2}$ is feasible in large-scale processing due to low energy requirements, as well as being non-carcinogenic, non-toxic, non-flammable, and thermodynamically stable and can be recycled and reused without purification. Although SFE- $\mathrm{CO}_{2}$ enhances the manufacturing of innovative food products by improving its shelf life without affecting quality, some limitations 
exist. A few limitations of SFE include price of the SFE equipment and reduction of enzymatic activities, including gene expression causing denaturation and lowered catalytic reactions through the formation of carbonic acid on the enzyme surface of a microorganism, as well in the food product (Knez et al., 2013).

\subsection{Summary}

The demand for soft cheeses, such as mozzarella and queso fresco, is rapidly increasing in the United States. Salt is one of the main components of soft cheeses which contain 0.7-3.5\% of salt. Salt is used to accentuate flavor, control microbial growth and maintain the cheese texture. Unfortunately, salt consumption has a negative effect on human health, contributing to hypertension and gastric cancer. Thus, salt content in food needs to be reduced to minimize the occurrence of cardiovascular disease and its associated mortality rate. More studies need to be done to find ways to minimize the salt content in cheese without affecting its sensory properties, texture, and microbial stability. Lowering the sodium content of cheese can prevent the development of cardiovascular diseases. Nevertheless, it is believed that pathogenic bacteria might have a higher growth rate in low-sodium cheese products, causing foodborne illness. $L$. monocytogenes, E. coli $\mathrm{O} 157: \mathrm{H} 7$, and Salmonella are the leading pathogens involved in foodborne illness. However, recent studies have demonstrated that salt concentration in cheese is not a predictor of bacterial growth, and it is not correlated with bacterial survival in cheese. Therefore, cheese with low salt content may be equally as safe as cheese with high salt content.

Since commercial soft cheeses are produced with pasteurized milk, contamination is more likely to occur during post-processing and handling. To prevent and minimize the risk of post-processing contamination and enhance the shelf-life of cheese, supercritical fluid with $\mathrm{CO}_{2}$ (SFE) might be used. SFE is a feasible non-thermal technology, which may be a viable option for commercial applications in the dairy industry. SFE can reduce the microbial population without modifying any other characteristics of the product. 
This study examined the growth of L. monocytogenes, Salmonella spp, and E.coli O157:H7 in low sodium mozzarella compared to typical sodium mozzarella cheese. It also evaluated the effects of Supercritical Fluid Extraction with $\mathrm{CO}_{2}$ to reduce L. innocua (a surrogate for L. monocytogenes) in Queso Fresco and Mozarella Cheese. 
Table 1-4: Effect of SFE as Antimicrobial in Different Food Matrix

\begin{tabular}{|c|c|c|c|c|c|}
\hline \multicolumn{2}{|c|}{ Food matrix } & $\begin{array}{l}\text { Microorgani } \\
\text { sm }\end{array}$ & Conditions & $\begin{array}{l}\text { Reductio } \\
\mathrm{n}\end{array}$ & Reference \\
\hline \multicolumn{2}{|c|}{ Apple cider } & E. coli $\mathrm{K} 12$ & $\begin{array}{l}\text { 7.6 } \mathrm{MPa}, 42{ }^{\circ} \mathrm{C}, 20 \mathrm{~min} \text {, } \\
8 \% \mathrm{CO}_{2} \text { concentration }\end{array}$ & $\begin{array}{l}7.6 \log \\
\mathrm{CFU} / \mathrm{g}\end{array}$ & $\begin{array}{l}\text { Yuk, H., Geveke, D., \& } \\
\text { Zhang, H. (2010) }\end{array}$ \\
\hline \multicolumn{2}{|c|}{ Apple cider } & E.coli $\mathrm{K} 12$ & $8 \% \mathrm{CO}_{2}$ concentration & $\mathrm{CFU} / \mathrm{g}$ & \\
\hline \multicolumn{2}{|c|}{ Apple cider } & E.coli $\mathrm{K} 12$ & $\begin{array}{l}7.6 \mathrm{MPa}, 34^{\circ} \mathrm{C}, 20 \mathrm{~min} \text {, } \\
10 \% \mathrm{CO}_{2} \text { concentration }\end{array}$ & $\begin{array}{l}5 \quad \log \\
\mathrm{CFU} / \mathrm{g}\end{array}$ & \\
\hline \multirow{2}{*}{$\begin{array}{l}\text { Dry } \\
\text { Ham }\end{array}$} & \multirow[t]{2}{*}{ Cured } & $\begin{array}{l}\text { L. } \\
\text { monocytogen }\end{array}$ & & $6 \quad \log$ & $\begin{array}{lll}\text { Ferrentino, } & \text { G. } & \text {, } \\
\text { Balzan,S., } & & \&\end{array}$ \\
\hline & & $\begin{array}{l}\text { es } \\
\text { L. }\end{array}$ & $12 \mathrm{MPa}, 50^{\circ} \mathrm{C}, 5 \mathrm{~min}$ & $\mathrm{CFU} / \mathrm{g}$ & Spilimbergo, S. (2013) \\
\hline \multirow{2}{*}{$\begin{array}{l}\text { Dry } \\
\text { Ham }\end{array}$} & Cured & monocytogen & & $7.9 \quad \log$ & \\
\hline & & $\begin{array}{l}\text { es } \\
L .\end{array}$ & $12 \mathrm{MPa}, 50^{\circ} \mathrm{C}, 15 \mathrm{~min}$ & $\mathrm{CFU} / \mathrm{g}$ & \\
\hline \multirow{2}{*}{$\begin{array}{l}\text { Dry } \\
\text { Ham }\end{array}$} & Cured & monocytogen & & $4.5 \quad \log$ & \\
\hline & & $\begin{array}{l}\text { es } \\
\text { L. }\end{array}$ & $12 \mathrm{MPa}, 45^{\circ} \mathrm{C}, 5 \mathrm{~min}$ & $\mathrm{CFU} / \mathrm{g}$ & \\
\hline \multirow{2}{*}{$\begin{array}{l}\text { Dry } \\
\text { Ham }\end{array}$} & Cured & monocytogen & & $5.5 \quad \log$ & \\
\hline & & $\begin{array}{l}\text { es } \\
\text { L. }\end{array}$ & $12 \mathrm{MPa}, 45^{\circ} \mathrm{C}, 15 \mathrm{~min}$ & $\begin{array}{l}\mathrm{CFU} / \mathrm{g} \\
\text { Total }\end{array}$ & \\
\hline \multirow{2}{*}{$\begin{array}{l}\text { Dry } \\
\text { Ham }\end{array}$} & Cured & monocytogen & & inactivati & \\
\hline & & $\begin{array}{l}e s \\
L .\end{array}$ & $12 \mathrm{MPa}, 45^{\circ} \mathrm{C}, 30 \mathrm{~min}$ & on & \\
\hline \multirow{2}{*}{$\begin{array}{l}\text { Dry } \\
\text { Ham }\end{array}$} & Cured & monocytogen & & $1.5 \log$ & \\
\hline & & es & $12 \mathrm{MPa}, 40^{\circ} \mathrm{C}, 5 \mathrm{~min}$ & $\mathrm{CFU} / \mathrm{g}$ & \\
\hline \multirow{2}{*}{$\begin{array}{l}\text { Dry } \\
\text { Ham }\end{array}$} & Cured & $\begin{array}{l}\text { L. } \\
\text { monocytogen }\end{array}$ & & $\begin{array}{l}\text { Total } \\
\text { inactivati }\end{array}$ & \\
\hline & & $\begin{array}{l}\text { es } \\
\text { L. }\end{array}$ & $12 \mathrm{MPa}, 40^{\circ} \mathrm{C}, 15 \mathrm{~min}$ & on & \\
\hline \multirow{2}{*}{$\begin{array}{l}\text { Dry } \\
\text { Ham }\end{array}$} & Cured & monocytogen & & $5 \quad \log$ & \\
\hline & & $\begin{array}{l}\text { es } \\
\text { L. }\end{array}$ & $12 \mathrm{MPa}, 40^{\circ} \mathrm{C}, 30 \mathrm{~min}$ & $\mathrm{CFU} / \mathrm{g}$ & \\
\hline \multirow{2}{*}{$\begin{array}{l}\text { Dry } \\
\text { Ham }\end{array}$} & Cured & monocytogen & & $6.9 \log$ & \\
\hline & & $\begin{array}{l}\text { es } \\
L\end{array}$ & $12 \mathrm{MPa}, 40^{\circ} \mathrm{C}, 60 \mathrm{~min}$ & $\mathrm{CFU} / \mathrm{g}$ & \\
\hline \multirow{2}{*}{$\begin{array}{l}\text { Dry } \\
\text { Ham }\end{array}$} & Cured & monocytogen & & $2.5 \quad \log$ & \\
\hline & & $\begin{array}{l}\text { es } \\
L\end{array}$ & $12 \mathrm{Mpa}, 35^{\circ} \mathrm{C}, 5 \mathrm{~min}$ & $\mathrm{CFU} / \mathrm{g}$ & \\
\hline \multirow{2}{*}{$\begin{array}{l}\text { Dry } \\
\text { Ham }\end{array}$} & Cured & monocytogen & & $3 \log$ & \\
\hline & & $\begin{array}{l}\text { es } \\
L .\end{array}$ & $12 \mathrm{MPa}, 35^{\circ} \mathrm{C}, 15 \mathrm{~min}$ & $\mathrm{CFU} / \mathrm{g}$ & \\
\hline \multirow{2}{*}{$\begin{array}{l}\text { Dry } \\
\text { Ham }\end{array}$} & Cured & monocytogen & & $3.2 \log$ & \\
\hline & & $\begin{array}{l}\text { es } \\
L\end{array}$ & $12 \mathrm{MPa}, 35^{\circ} \mathrm{C}, 30 \mathrm{~min}$ & $\mathrm{CFU} / \mathrm{g}$ & \\
\hline \multirow{2}{*}{$\begin{array}{l}\text { Dry } \\
\text { Ham }\end{array}$} & Cured & monocytogen & & $3.9 \log$ & \\
\hline & & $\begin{array}{l}e s \\
L\end{array}$ & $12 \mathrm{MPa}, 35^{\circ} \mathrm{C}, 60 \mathrm{~min}$ & $\mathrm{CFU} / \mathrm{g}$ & \\
\hline \multirow{2}{*}{$\begin{array}{l}\text { Dry } \\
\text { Ham }\end{array}$} & Cured & monocytogen & & $4 \log$ & \\
\hline & & es & $8 \mathrm{MPa}, 50^{\circ} \mathrm{C}, 5 \mathrm{~min}$ & $\mathrm{CFU} / \mathrm{g}$ & \\
\hline
\end{tabular}


$L$.

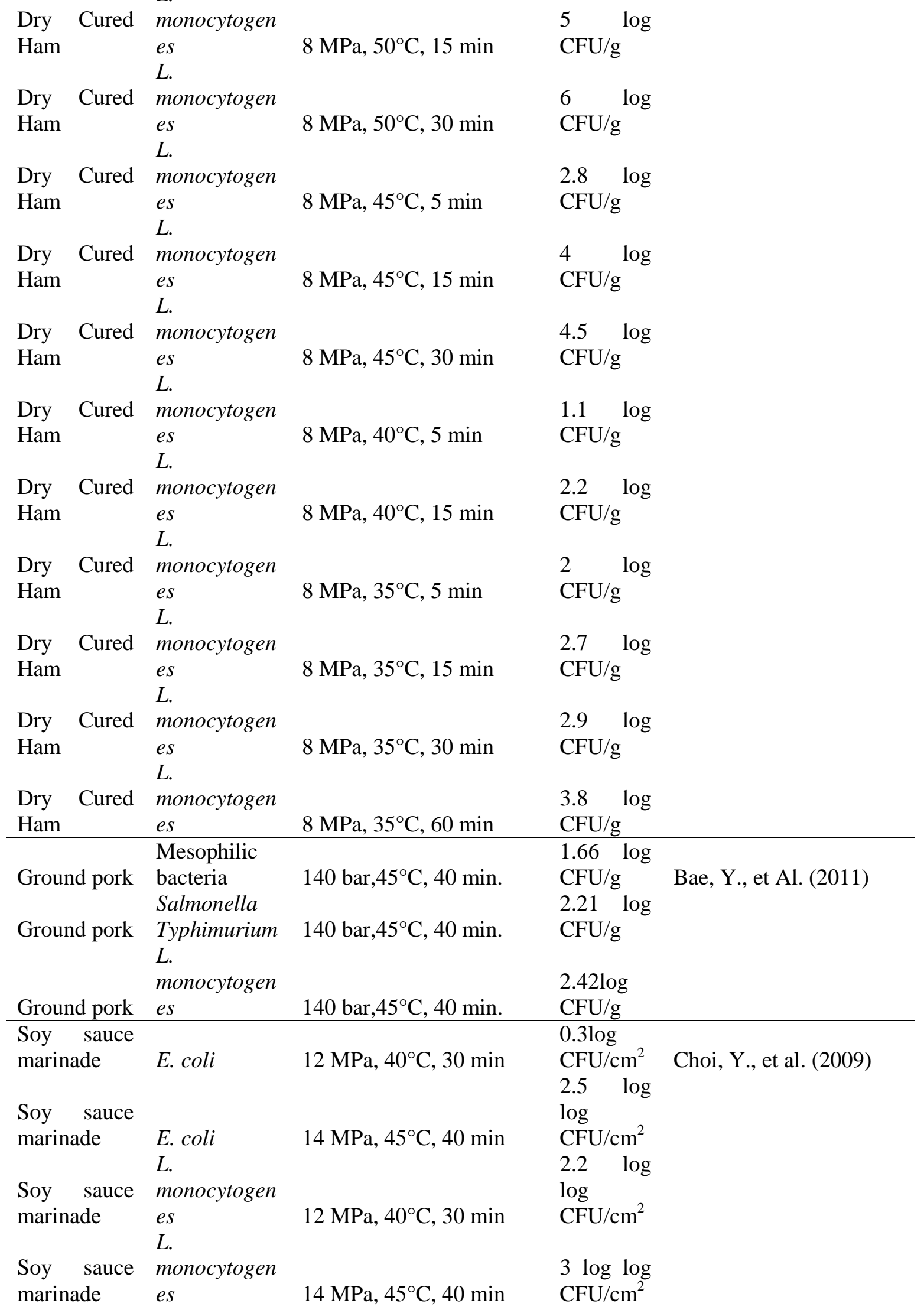




\begin{tabular}{|c|c|c|c|}
\hline $\begin{array}{l}\text { Soy sauce } \\
\text { marinade }\end{array}$ & $\begin{array}{l}\text { E.coli } \\
\text { O157:H7 }\end{array}$ & $12 \mathrm{MPa}, 40^{\circ} \mathrm{C}, 30 \mathrm{~min}$ & $\begin{array}{l}1.1 \quad \log \\
\mathrm{CFU} / \mathrm{cm}^{2}\end{array}$ \\
\hline Soy sauce & E.coli & & $2.6 \quad \log$ \\
\hline marinade & O157:H7 & $14 \mathrm{MPa}, 45^{\circ} \mathrm{C}, 40 \mathrm{~min}$ & $\mathrm{CFU} / \mathrm{cm}^{2}$ \\
\hline Soy sauce & Salmonella & & $1.1 \log$ \\
\hline marinade & Typhimurium & $12 \mathrm{MPa}, 40^{\circ} \mathrm{C}, 30 \mathrm{~min}$ & $\mathrm{CFU} / \mathrm{cm}^{2}$ \\
\hline Soy sauce & Salmonella & & $3.5 \log$ \\
\hline $\begin{array}{l}\text { marinade } \\
\text { Hot-pepper }\end{array}$ & Typhimurium & $14 \mathrm{MPa}, 45^{\circ} \mathrm{C}, 40 \mathrm{~min}$ & $\mathrm{CFU} / \mathrm{cm}^{2}$ \\
\hline $\begin{array}{l}\text { paste } \\
\text { marinate }\end{array}$ & E. coli & $12 \mathrm{MPa}, 40^{\circ} \mathrm{C}, 30 \mathrm{~min}$ & $\begin{array}{l}0.8 \quad \log \\
\mathrm{CFU} / \mathrm{cm}^{2}\end{array}$ \\
\hline $\begin{array}{l}\text { Hot-pepper } \\
\text { paste }\end{array}$ & L. coll & $12 \mathrm{NIF} \mathrm{d}, 40 \mathrm{C}, 50 \mathrm{mIm}$ & \\
\hline marinate & E. coli & $14 \mathrm{MPa}, 45^{\circ} \mathrm{C}, 40 \mathrm{~min}$ & $\mathrm{CFU} / \mathrm{cm}^{2}$ \\
\hline $\begin{array}{l}\text { Hot-pepper } \\
\text { paste }\end{array}$ & $\begin{array}{l}L . \\
\text { monocytogen }\end{array}$ & & $0.9 \quad \log$ \\
\hline marinate & es & $12 \mathrm{MPa}, 40^{\circ} \mathrm{C}, 30 \mathrm{~min}$ & $\mathrm{CFU} / \mathrm{cm}^{2}$ \\
\hline Hot-pepper & $L$ & & \\
\hline $\begin{array}{l}\text { paste } \\
\text { marinate }\end{array}$ & $\begin{array}{l}\text { monocytogen } \\
\text { es }\end{array}$ & $14 \mathrm{MPa}, 45^{\circ} \mathrm{C}, 40 \mathrm{~min}$ & $\begin{array}{l}2.4 \quad \log \\
\mathrm{CFU} / \mathrm{cm}^{2}\end{array}$ \\
\hline $\begin{array}{l}\text { Hot-pepper } \\
\text { paste }\end{array}$ & E.coli & & \\
\hline $\begin{array}{l}\text { marinate } \\
\text { Hot-pepper }\end{array}$ & $\mathrm{O} 157: \mathrm{H} 7$ & $12 \mathrm{MPa}, 40^{\circ} \mathrm{C}, 30 \mathrm{~min}$ & $\mathrm{CFU} / \mathrm{cm}^{2}$ \\
\hline paste & E.coli & & $2 \log$ \\
\hline $\begin{array}{l}\text { marinate } \\
\text { Hot-pepper }\end{array}$ & $\mathrm{O} 157: \mathrm{H} 7$ & $14 \mathrm{MPa}, 45^{\circ} \mathrm{C}, 40 \mathrm{~min}$ & $\mathrm{CFU} / \mathrm{cm}^{2}$ \\
\hline paste & Salmonella & & $0.3 \quad \log$ \\
\hline $\begin{array}{l}\text { marinate } \\
\text { Hot-pepper }\end{array}$ & Typhimurium & $12 \mathrm{MPa}, 40^{\circ} \mathrm{C}, 30 \mathrm{~min}$ & $\mathrm{CFU} / \mathrm{cm}^{2}$ \\
\hline paste & Salmonella & & $2.5 \quad \log$ \\
\hline $\begin{array}{l}\text { marinate } \\
\text { Soy sauce }\end{array}$ & Typhimurium & $14 \mathrm{MPa}, 45^{\circ} \mathrm{C}, 40 \mathrm{~min}$ & $\mathrm{CFU} / \mathrm{cm}^{2}$ \\
\hline $\begin{array}{l}\text { marinated } \\
\text { pork }\end{array}$ & E. coli & $12 \mathrm{MPa}, 40^{\circ} \mathrm{C}, 30 \mathrm{~min}$ & $\begin{array}{l}0.5 \quad \log \\
\mathrm{CFU} / \mathrm{cm}^{2}\end{array}$ \\
\hline Soy sauce & & & \\
\hline $\begin{array}{l}\text { marinated } \\
\text { pork }\end{array}$ & E. coli & $14 \mathrm{MPa}, 45^{\circ} \mathrm{C}, 40 \mathrm{~min}$ & $\begin{array}{l}2.4 \quad \log \\
\mathrm{CFU} / \mathrm{cm}^{2}\end{array}$ \\
\hline Soy sauce & $L$ & & \\
\hline $\begin{array}{l}\text { marinated } \\
\text { pork }\end{array}$ & $\begin{array}{l}\text { monocytogen } \\
\text { es }\end{array}$ & $12 \mathrm{MPa}, 40^{\circ} \mathrm{C}, 30 \mathrm{~min}$ & $\begin{array}{l}1 \quad \log \\
\mathrm{CFU} / \mathrm{cm}^{2}\end{array}$ \\
\hline Soy sauce & $L$. & & \\
\hline $\begin{array}{l}\text { marinated } \\
\text { pork }\end{array}$ & $\begin{array}{l}\text { monocytogen } \\
\text { es }\end{array}$ & $14 \mathrm{MPa}, 45^{\circ} \mathrm{C}, 40 \mathrm{~min}$ & $\begin{array}{l}2.5 \quad \log \\
\mathrm{CFU} / \mathrm{cm}^{2}\end{array}$ \\
\hline $\begin{array}{l}\text { Soy sauce } \\
\text { marinated } \\
\text { pork }\end{array}$ & $\begin{array}{l}\text { E.coli } \\
\text { O157:H7 }\end{array}$ & $12 \mathrm{MPa}, 40^{\circ} \mathrm{C}, 30 \mathrm{~min}$ & $\begin{array}{l}0.5 \quad \log \\
\mathrm{CFU} / \mathrm{cm}^{2}\end{array}$ \\
\hline $\begin{array}{l}\text { Soy sauce } \\
\text { marinated } \\
\text { pork }\end{array}$ & $\begin{array}{l}\text { E.coli } \\
\text { O157:H7 }\end{array}$ & $14 \mathrm{MPa}, 45^{\circ} \mathrm{C}, 40 \mathrm{~min}$ & $\begin{array}{l}2.3 \quad \log \\
\mathrm{CFU} / \mathrm{cm}^{2}\end{array}$ \\
\hline
\end{tabular}




\begin{tabular}{|c|c|c|c|c|}
\hline $\begin{array}{l}\text { Soy sauce } \\
\text { marinated } \\
\text { pork } \\
\text { Soy sauce } \\
\text { marinated } \\
\text { pork }\end{array}$ & $\begin{array}{l}\text { Salmonella } \\
\text { Typhimurium } \\
\text { Salmonella } \\
\text { Typhimurium }\end{array}$ & $12 \mathrm{MPa}, 40^{\circ} \mathrm{C}, 30 \mathrm{~min}$ & $\begin{array}{l}0.5 \quad \log \\
\mathrm{CFU} / \mathrm{cm}^{2} \\
2.4 \quad \log \\
\mathrm{CFU} / \mathrm{cm}^{2}\end{array}$ & \\
\hline $\begin{array}{l}\text { Alfalfa } \\
\text { seeds } \\
\text { Alfalfa } \\
\text { seeds } \\
\text { Alfalfa } \\
\text { seeds } \\
\text { Alfalfa } \\
\text { seeds } \\
\text { Alfalfa } \\
\text { seeds } \\
\text { Alfalfa } \\
\text { seeds } \\
\text { Alfalfa } \\
\text { seeds }\end{array}$ & $\begin{array}{l}\text { E. coli } \mathrm{K} 12 \\
\text { E. coli } \mathrm{K} 12 \\
\text { E. coli } \mathrm{K} 12 \\
\text { E. coli } \mathrm{K} 12 \\
\text { Aerobic } \\
\text { bacteria }\end{array}$ & $\begin{array}{l}27.6 \mathrm{MPa}, 50^{\circ} \mathrm{C}, 60 \mathrm{~min} \\
27.6 \mathrm{MPa}, 50^{\circ} \mathrm{C}, 60 \mathrm{~min}\end{array}$ & $\begin{array}{l}26.60 \% \\
70.80 \% \\
68.10 \% \\
81.30 \% \\
81.30 \% \\
92.80 \% \\
85.6 \% \\
\end{array}$ & Mazzoni,A. et al. (2001). \\
\hline $\begin{array}{l}\text { Powdered } \\
\text { infant } \\
\text { formula } \\
\text { Powdered }\end{array}$ & $\begin{array}{l}\text { Cronobacter } \\
\text { spp. }\end{array}$ & $15 \mathrm{MPa}, 63^{\circ} \mathrm{C}, 30 \mathrm{~min}$ & $\begin{array}{l}1.6 \quad \log \\
\text { CFU/g }\end{array}$ & $\begin{array}{l}\text { Kim, S. , Kim, O. , \& } \\
\text { Rhee, M. (2010). }\end{array}$ \\
\hline $\begin{array}{l}\text { Infant } \\
\text { Formula } \\
\text { Powdered }\end{array}$ & $\begin{array}{l}\text { Cronobacter } \\
\text { spp. }\end{array}$ & $15 \mathrm{MPa}, 68^{\circ} \mathrm{C}, 10 \mathrm{~min}$ & $\begin{array}{l}1.54 \log \\
\mathrm{CFU} / \mathrm{g}\end{array}$ & \\
\hline $\begin{array}{l}\text { Infant } \\
\text { Formula } \\
\text { Powdered }\end{array}$ & $\begin{array}{l}\text { Cronobacter } \\
\text { spp. }\end{array}$ & $15 \mathrm{MPa}, 73^{\circ} \mathrm{C}, 10 \mathrm{~min}$ & $\begin{array}{l}2.25 \log \\
\mathrm{CFU} / \mathrm{g}\end{array}$ & \\
\hline $\begin{array}{l}\text { Infant } \\
\text { Formula } \\
\text { Powdered }\end{array}$ & $\begin{array}{l}\text { Cronobacter } \\
\text { spp. }\end{array}$ & $15 \mathrm{MPa}, 73^{\circ} \mathrm{C}, 30 \mathrm{~min}$ & $\begin{array}{l}\text { Undetecta } \\
\text { ble levels }\end{array}$ & \\
\hline $\begin{array}{l}\text { Infant } \\
\text { Formula } \\
\text { Powdered }\end{array}$ & $\begin{array}{l}\text { Cronobacter } \\
\text { spp. }\end{array}$ & $20 \mathrm{MPa}, 63^{\circ} \mathrm{C}, 10 \mathrm{~min}$ & $\begin{array}{l}1.61 \log \\
\mathrm{CFU} / \mathrm{g}\end{array}$ & \\
\hline $\begin{array}{l}\text { Infant } \\
\text { Formula } \\
\text { Powdered }\end{array}$ & $\begin{array}{l}\text { Cronobacter } \\
\text { spp. }\end{array}$ & $20 \mathrm{MPa}, 68^{\circ} \mathrm{C}, 20 \mathrm{~min}$ & $\begin{array}{l}3.99 \log \\
\text { CFU/g }\end{array}$ & \\
\hline $\begin{array}{l}\text { Infant } \\
\text { Formula } \\
\text { Powdered }\end{array}$ & $\begin{array}{l}\text { Cronobacter } \\
\text { spp. }\end{array}$ & $20 \mathrm{MPa}, 73^{\circ} \mathrm{C}, 20 \mathrm{~min}$ & $\begin{array}{l}\text { Undetecta } \\
\text { ble levels }\end{array}$ & \\
\hline $\begin{array}{l}\text { Infant } \\
\text { Formula } \\
\text { Powdered }\end{array}$ & $\begin{array}{l}\text { Cronobacter } \\
\text { spp. }\end{array}$ & $20 \mathrm{MPa}, 73^{\circ} \mathrm{C}, 30 \mathrm{~min}$ & $\begin{array}{l}\text { Undetecta } \\
\text { ble levels }\end{array}$ & \\
\hline $\begin{array}{l}\text { Infant } \\
\text { Formula } \\
\text { Powdered }\end{array}$ & $\begin{array}{l}\text { Cronobacter } \\
\text { spp. }\end{array}$ & $25 \mathrm{MPa}, 63^{\circ} \mathrm{C}, 30 \mathrm{~min}$ & $\begin{array}{l}2.50 \quad \log \\
\mathrm{CFU} / \mathrm{g}\end{array}$ & \\
\hline $\begin{array}{l}\text { Infant } \\
\text { Formula }\end{array}$ & $\begin{array}{l}\text { Cronobacter } \\
\text { spp. }\end{array}$ & $25 \mathrm{MPa}, 68^{\circ} \mathrm{C}, 30 \mathrm{~min}$ & $\begin{array}{l}3.99 \log \\
\mathrm{CFU} / \mathrm{g}\end{array}$ & \\
\hline
\end{tabular}




\begin{tabular}{|c|c|c|c|c|}
\hline $\begin{array}{l}\text { Powdered } \\
\text { Infant } \\
\text { Formula } \\
\text { Powdered } \\
\text { Infant } \\
\text { Formula }\end{array}$ & $\begin{array}{l}\text { Cronobacter } \\
\text { spp. } \\
\text { Cronobacter } \\
\text { spp. }\end{array}$ & $25 \mathrm{MPa}, 73^{\circ} \mathrm{C}, 20 \mathrm{~min}$ & $\begin{array}{l}\text { Undetecta } \\
\text { ble levels } \\
\text { Undetecta } \\
\text { ble levels }\end{array}$ & \\
\hline Raw milk & $\begin{array}{l}\text { Pseudomona } \\
s \\
\text { fluorescences } \\
\text { Pseudomona } \\
\text { s }\end{array}$ & $\begin{array}{l}20.7 \mathrm{MPa}, 30^{\circ} \mathrm{C}, 10 \mathrm{~min} \text {, } \\
132 \mathrm{~g} / \mathrm{kg} \\
\text { concentration } \\
20.7 \mathrm{MPa}, 35^{\circ} \mathrm{C}, 10 \mathrm{~min} \text {, } \\
132 \mathrm{~g} / \mathrm{kg}\end{array}$ & $\begin{array}{l}2.9 \quad \log \\
\mathrm{CFU} / \mathrm{ml} \\
5 \quad \log \end{array}$ & $\begin{array}{l}\text { Werner, B. \& Hotchkiss, } \\
\text { J. (2006). }\end{array}$ \\
\hline Raw milk & fluorescences & $\begin{array}{l}20.7 \mathrm{MPa}, 30^{\circ} \mathrm{C}, 10 \mathrm{~min} \text {, } \\
\text { concentration }\end{array}$ & $\mathrm{CFU} / \mathrm{ml}$ & \\
\hline Raw milk & $\begin{array}{l}\text { Psychrotroph } \\
\text { Psychrotroph }\end{array}$ & $\begin{array}{ll}132 \mathrm{~g} / \mathrm{kg} & \mathrm{CO}_{2} \\
\text { concentration } & \\
20.7 \mathrm{MPa}, 35^{\circ} \mathrm{C}, 10 \mathrm{~min}, \\
132 \mathrm{~g} / \mathrm{kg} \\
\text { concentration }\end{array}$ & $\begin{array}{l}3.8 \quad \log \\
\mathrm{CFU} / \mathrm{ml} \\
5.4 \quad \log \\
\mathrm{CFU} / \mathrm{ml}\end{array}$ & \\
\hline $\begin{array}{l}\text { Gouda } \\
\text { cheese } \\
\text { Gouda } \\
\text { cheese } \\
\text { Majorero } \\
\text { cheese } \\
\text { Majorero } \\
\text { cheese } \\
\text { Majorero } \\
\text { cheese }\end{array}$ & $\begin{array}{l}\text { Aerobic } \\
\text { bacteria } \\
\text { Lactococi } \\
\text { bacteria } \\
\text { Aerobic } \\
\text { bacteria } \\
\text { Lactococi } \\
\text { bacteria } \\
\text { Lactobacilli } \\
\text { bacteria }\end{array}$ & $\begin{array}{l}10 \mathrm{MPa}, 35^{\circ} \mathrm{C}, 50 \mathrm{~min} \\
10 \mathrm{MPa}, 35^{\circ} \mathrm{C}, 50 \mathrm{~min} \\
30 \mathrm{MPa}, 35^{\circ} \mathrm{C}, 50 \mathrm{~min} \\
40 \mathrm{MPa}, 35^{\circ} \mathrm{C}, 50 \mathrm{~min}\end{array}$ & $\begin{array}{l}3.19 \log \\
\mathrm{CFU} / \mathrm{g} \\
2.8 \log \\
\mathrm{CFU} / \mathrm{g} \\
2.72 \log \\
\mathrm{CFU} / \mathrm{g} \\
5.01 \log \\
\mathrm{CFU} / \mathrm{g} \\
4.31 \log \\
\mathrm{CFU} / \mathrm{g}\end{array}$ & $\begin{array}{l}\text { Sanchez-Macias, D., et } \\
\text { al. (2013). }\end{array}$ \\
\hline
\end{tabular}




\title{
CHAPTER 2: EFFECT OF SODIUM REDUCTION ON THE GROWTH OF PATHOGENS IN MOZZARELLA CHEESE
}

\author{
2.1 Introduction
}

Cheese consumption is increasing each year in the United States. In 2014, 11.5 billion pounds of cheese were produced, which it was approximately $30 \%$ more cheese than was produced in 2004 ( 8.9 billion pounds). Mozzarella represented 34.3\% of the total cheese manufactured in this country (USDA, 2015). Cheese provides a good source of protein, fat, vitamins, and minerals (Walther \& Schmid, 2008). However, cheese also contributes to the sodium daily intake, due to its presence in almost every meal, particularly Mozzarella cheese. A serving size of Mozzarella cheese (28 g) has approximately $148 \mathrm{mg}$ of sodium, contributing to $7 \%$ of the sodium daily intake recommended for an individual (Adams, 2014). Excessive daily consumption of sodium can cause health problems. As a consequence of high sodium consumption, 850,000 people in United States die each year. Researchers have suggested that a reduction of the sodium content in food by $1.3 \mathrm{~g}$ per day would decrease the prevalence of hypertension by $20 \%$ and the mortality rate provoked by vasculocerebral incidents by $14 \%$ (Liem et al, 2011; Cruz et al., 2011; Havas et al., 2009).

Salt $(\mathrm{NaCl})$ plays an important role in cheese by enhancing flavor, influencing texture, and controlling the growth of microorganisms. Salt also enhances aroma perception, delivering bitter and sour taste profiles for a cheese and influences texture by contributing to enzymatic activities, such as the fermentation of sugars, which are essential for the body and texture of cheese (Cruz et al., 2011). Salt controls the growth of microorganisms by reducing water activity and increasing the osmotic pressure in the aqueous phase of food. A low water activity and high osmotic pressure causes an interruption of the mass transfer through cell membranes, which results in ionic losses and prevents bacterial growth (Cruz et al., 2011). 
To help prevent diseases caused by the high consumption of sodium, dairy products with reduced sodium content have been developed. However, reducing the sodium content in cheeses could result in a potential microbial safety concern. Foodborne illnesses caused by the consumption of cheese have been reported in 90 outbreaks from 1998 to 2011 in the US. Mozzarella cheese was responsible for six out of the 90 cases. Of the outbreaks caused by cheese, there were 1,882 cases of illnesses, 230 cases of hospitalizations, and six cases of deaths. In the period from 1998 to 2008, dairy products were rated as the second highest cause of foodborne illness after leafy greens. Dairy products were also rated as the number one cause of hospitalization and the second highest to cause death (Gould et al., 2014; CDC, 2012). Lowering the sodium content of cheese may cause an increase in the growth and or survival of pathogenic bacteria (Shrestha et al. 2011a ; Shrestha et al., 2011b). Therefore, it is essential to investigate whether lowering the salt content of Mozzarella cheese affects the survival of pathogenic bacteria since foodborne illness due to cheese consumption is already a risk.

Some researchers have studied the role of salt as an inhibitor of microbial growth in cheese. Mohammadi et al. (2009) studied the survival of E. coli O157:H7 in cheeses made with different salt brine concentrations $\left(6 \%\right.$ and $8 \%$ ). During storage at $4{ }^{\circ} \mathrm{C}$ for 60 days, the E. coli O157:H7 population was reduced significantly in some cheeses, but increased in other cheeses regardless of the salt brine concentration. Escherichia coli reduction was due not salt content, but due to others intrinsic factors within the cheese matrix. Other researchers also studied the fate of L. monocytogenes and Salmonella in low (0.7\%) and regular (1.8\%) Cheddar cheese. Listeria monocytogenes and Salmonella counts gradually decreased for each treated cheese regardless of salt concentration (Shrestha et al. 2011a ; Shrestha et al., 2011b). However, Hystead et al. (2013) reported that L. monocytogenes inoculated in Cheddar cheese after two and three weeks of cheese aging survived and grew better in low sodium (between 1.26 to $1.65 \%$ ) cheese compared to regular sodium Cheddar cheese during storage day at $4{ }^{\circ} \mathrm{C}$, but growth was not enhanced at $12^{\circ} \mathrm{C}$. 
Thus, the role of salt concentration in cheese as a control for bacterial growth is still unclear and therefore, an investigation of whether lowering the salt content of Mozzarella cheese supports the survival of pathogens is essential.

The objective of this study was to compare the growth of pathogens on reduced and regular sodium Mozzarella cheese at $4{ }^{\circ} \mathrm{C}$ and $12{ }^{\circ} \mathrm{C}$ for 90 and 30 days, respectively. The growth of spoilage organisms, water activity and $\mathrm{pH}$ during storage were also evaluated.

\subsection{Materials and Methods}

\subsubsection{Cheese Preparation}

Low-moisture, pasteurized, whole milk Mozzarella cheese was obtained from a commercial manufacturer. Two cheese types were provided: reduced (1.62\%) and regular sodium $(2.15 \%)$. Cheeses were stored at $-9.4{ }^{\circ} \mathrm{C}$ until a week before the experiment (inoculation), during which cheeses were maintained at $4{ }^{\circ} \mathrm{C}$. Each type of Mozzarella cheese (regular and reduced sodium) was shredded a day prior to the experiment. On the first day of the experiment, $15 \mathrm{~g}$ of each cheese was placed in a heat sealable polyethylene bag (Thermo Fisher Scientific, Waltham, MA).

\section{$\underline{\text { 2.2.2 Inoculum Preparation }}$}

Stock cultures of L. monocytogenes, Salmonella, and E. coli O157:H7 were maintained frozen $\left(-70^{\circ} \mathrm{C}\right)$ for long-term preservation. Working cultures were streaked on Tryptic Soy Agar (TSA, Neogen, Lansing, MI) and incubated at $35{ }^{\circ} \mathrm{C}$ for $24 \mathrm{~h}$. Isolated colonies of each strain were separately grown in Tryptic Soy Broth (TSB; Neogen Corp., Lansing, MI) by placing a loopful of culture colony into $10 \mathrm{ml}$ of TSB at $35^{\circ} \mathrm{C}$ for $24 \mathrm{~h}$. (Table 1). Then, a five-strain mixture of each species was prepared by combining the same volume of each strain in a sterile tube. Each bacterial mixture was separately centrifuged (3000 rpm for $15 \mathrm{~min}$ ), washed twice with $0.1 \%$ peptone water, and resuspended in $0.1 \%$ peptone water. 
The initial stock concentration was determined by Direct Microscope Count (DMC), using a hemocytometer (Hausser Scientific, Horsham, PA). Proper dilutions of each washed mixture were diluted with $0.1 \%$ peptone water to achieve approximately $10^{2}$ to $10^{3} \mathrm{CFU} / \mathrm{g}$ of cheese. The stock concentration was confirmed by plating on selective media; Xylose Lysine Deoxycholate Agar (XLD, Neogen, Lansing, MI), Modified Oxford Agar (MOX, Difco, Sparks, MD) containing MOX supplement (Becton, Dickinson and Company, Franklin Lakes, NJ), MacConkey Agar with Sorbitol (SMAC, Neogen, Lansing, MI) for Salmonella, L. monocytogenes, and E. coli $\mathrm{O} 157: \mathrm{H} 7$, respectively.

\subsubsection{Pathogen Inoculation of Reduced and Regular Sodium Mozzarella Cheese}

Each cheese sample within a heat sealable bag was individually inoculated with $40 \mu \mathrm{l}$ (twice with $20 \mu \mathrm{l}$ ) of Salmonella, L. monocytogenes or E. coli 0157:H7 at a target concentration of $10^{2}-10^{3} \mathrm{CFU} / \mathrm{g}$. Uninoculated samples were used as a control. Samples were vacuum sealed and then stored at $4{ }^{\circ} \mathrm{C}$ and $12{ }^{\circ} \mathrm{C}$. Samples stored at $4{ }^{\circ} \mathrm{C}$ were tested after $0,1,7,15,30,60$, and 90 days, while samples stored at $12{ }^{\circ} \mathrm{C}$ were tested after $0,1,3,7,15$, and 30 days. The experiment was repeated twice by assaying two samples per trial. Samples stored at $12{ }^{\circ} \mathrm{C}$ were only held for 30 days since a more rapid growth of the microorganism was expected.

\subsubsection{Microbial Analysis}

On each test day, inoculated samples were tested for the pathogenic organism, and uninoculated samples were tested for $\mathrm{pH}$, water activity, coliforms, psychrotrophs, yeast, and mold counts. For all microbial enumerations, $15 \mathrm{~g}$ of cheese was blended with $135 \mathrm{ml}$ of $0.1 \%$ peptone water and homogenized in a stomacher for $60 \mathrm{~s}$. Then, the appropriate serial dilution was achieved on selective media. Salmonella strains were plated on XLD and incubated at $35^{\circ} \mathrm{C}$ for $24 \mathrm{~h}$, Listeria monocytogenes was plated on MOX containing MOX supplement and were incubated at $35^{\circ} \mathrm{C}$ for $24-48 \mathrm{~h}$, E. coli $\mathrm{O} 157: \mathrm{H} 7$ was plated on SMAC and incubated for $24 \mathrm{~h}$ at $35^{\circ}$ C. Coliforms plated on Violet Red Bile Agar (VRBA, Neogen, Lansing, MI) were incubated 
for $24 \mathrm{~h}$ at $35^{\circ} \mathrm{C}$, psychrotrophs were plated on Standard Method Agar (SMA, Neogen, Lansing, MI) were incubated at $8{ }^{\circ} \mathrm{C}$ for 10 days. Yeast and mold on Potato Dextrose Agar (PDA, Remel Products, Lenexa, KS) were incubated at $20-25{ }^{\circ} \mathrm{C}$ for 2-7 days. Colonies of each organism were counted and recorded.

\subsubsection{Physio-Chemical Analysis}

For $\mathrm{pH}$ measurements, cheese was mixed with distilled water to a 1:1 ratio and the cheese slurry was then measured using a $\mathrm{pH}$ meter (Oakton Instruments, Vernon Hills, IL). Water activity measurement $\left(\mathrm{A}_{\mathrm{w}}\right)$ was carried out using a water activity meter (AquaLab 4TE; Decagon Devices Inc., Pullman, WA).

Table 2-1: Bacteria used in cheese inoculation

\begin{tabular}{|c|c|c|}
\hline Bacteria & Strain & Isolation Information \\
\hline Listeria monocytogenes $^{1}$ & NRRL B-33000 & Food isolate: Cheese, CA USA \\
\hline Listeria monocytogenes 1 & NRRL B-33096 & Cheese Curd, CA USA \\
\hline Listeria monocytogenes $^{1}$ & NRRL B-33106 & Raw Milk, MA USA \\
\hline Listeria monocytogenes ${ }^{1}$ & NRRL B-33113 & Cotija Fresco Cheese, CA USA \\
\hline Listeria monocytogenes $^{1}$ & NRRL B-33445 & Cheese, IL USA \\
\hline Escherichia coli $0157: H 7^{2}$ & NFPA 4200 & $\begin{array}{l}\text { Hamburger Isolate; } \quad \text { Jack-in-the-Box } \\
\text { outbreak }\end{array}$ \\
\hline Escherichia coli $0157: H 7^{2}$ & NFPA 4212 & Salami outbreak; DC USA \\
\hline Escherichia coli O157:H7 ${ }^{2}$ & NFPA 4213 & Apple Cider Outbreak, CT USA \\
\hline Escherichia coli O157:H7 ${ }^{2}$ & NFPA 4217 & Lettuce Outbreak; Patient Isolate \\
\hline Escherichia coli $0157: H 7^{2}$ & NFPA 4219 & Apple Juice Outbreak \\
\hline Salmonella javiana ${ }^{3}$ & $\begin{array}{l}\text { ATCC } \quad \text { BAA } \\
1593\end{array}$ & $\begin{array}{l}\text { Human Isolate; linked to fresh Roma } \\
\text { tomatoes, PA, USA }\end{array}$ \\
\hline Salmonella heidelberg ${ }^{3}$ & FSL S5-448 & Human Isolate \\
\hline Salmonella montevideo ${ }^{3}$ & FSL S5-630 & Bovine Isolate \\
\hline Salmonella oranienburg ${ }^{3}$ & FSL S5-642 & Human Isolate \\
\hline $\begin{array}{l}\text { Salmonella typhimurium DT } \\
104^{3}\end{array}$ & FSL W1-030 & Human Isolate \\
\hline
\end{tabular}

Source: ${ }^{1}$ Agricultural Research Service (Peoria, IL), ${ }^{2}$ Agricultural Research Service (Peoria, IL),

${ }^{3}$ International Life Sciences Institute, (Cornell University; Ithaca, NY)

\subsubsection{Data Analysis}

The experiment was repeated twice $(n=4)$ and data points were expressed as the mean \pm standard deviation. Analysis of variance (ANOVA) and Tukey's test were used to assess significant differences $(\mathrm{p}<0.05)$ among the treatments; the ANOVA was performed by repeated 
measurements using a mixed procedure. The effect of replication between trials was blocked to avoid any variations for each replicate. Samples below the detection limit $<1$ log CFU/g were analyzed as $0.5 \log$ CFU/g. JMP software was used for the analysis (version Pro 11; SAS Institute Inc., Cary, NC).

\subsection{Results}

Populations of $L$. monocytogenes were not significantly different between regular and reduced sodium mozzarella cheeses at $4{ }^{\circ} \mathrm{C}$ during 90 days of storage $(\mathrm{p}<0.05)$. Populations of L. monocytogenes decreased by approximately $1.7 \log \mathrm{CFU} / \mathrm{g}$ and $1.8 \log \mathrm{CFU} / \mathrm{g}$ in reduced and regular sodium Mozzarella cheese stored at $4{ }^{\circ} \mathrm{C}$ for 90 days, respectively (Table 2-2). Listeria monocytogenes started to decrease on day 15 and 30 for regular and reduced sodium Mozzarella cheese stored at $4^{\circ} \mathrm{C}$, respectively. At $12^{\circ} \mathrm{C}$, populations of $L$. monocytogenes were significant different $(\mathrm{p}<0.05)$ between regular and reduced sodium Mozzarella cheese. Counts of $L$. monocytogenes were approximately $1 \log \mathrm{CFU} / \mathrm{g}$ greater in reduced as compared with regular sodium Mozzarella cheese during the 30 days of storage at $12^{\circ} \mathrm{C}$. Populations of $L$. monocytogenes were constant in regular sodium mozzarella cheese, but increased significantly by approximately $1 \log$ CFU/g on day 30 for reduced sodium Mozzarella Cheese. 
Table 2-2: Behavior of L. monocytogenes (log CFU/g) in Regular and Reduced Sodium Mozzarella Cheese Stored at 4 and $12{ }^{\circ} \mathrm{C}$

\begin{tabular}{|c|c|c|c|c|}
\hline \multirow[b]{3}{*}{ Day } & \multicolumn{4}{|l|}{ Temperature } \\
\hline & \multicolumn{2}{|l|}{$4{ }^{\circ} \mathrm{C}$} & \multicolumn{2}{|l|}{$12{ }^{\circ} \mathrm{C}$} \\
\hline & Regular Sodium & Reduced Sodium & Regular Sodium & Reduced Sodium \\
\hline 0 & $3.33 \pm 0.17^{\mathrm{Aa}}$ & $3.37 \pm 0.20^{\mathrm{A}}$ & $3.33 \pm 0.17^{\mathrm{Aa}}$ & $3.37 \pm 0.20^{\mathrm{Aa}}$ \\
\hline 1 & $3.30 \pm 0.14^{\mathrm{Aa}}$ & $3.20 \pm 0.08^{\mathrm{Aa}}$ & $3.22 \pm 0.18^{\mathrm{Aa}}$ & $3.11 \pm 0.08^{\mathrm{Aa}}$ \\
\hline 3 & NT & NT & $2.95 \pm 0.33^{\mathrm{Ab}}$ & $3.12 \pm 0.23^{\mathrm{Aa}}$ \\
\hline 7 & $3.18 \pm 0.09^{\mathrm{Aa}}$ & $3.08 \pm 0.09^{\mathrm{Aa}}$ & $3.10 \pm 0.12^{\mathrm{Aa}}$ & $3.10 \pm 0.06^{\mathrm{Aa}}$ \\
\hline 15 & $2.90 \pm 0.15^{\mathrm{Ab}}$ & $3.07 \pm 0.15^{\mathrm{Aa}}$ & $2.75 \pm 0.20^{\mathrm{Ab}}$ & $3.09 \pm 0.09^{\mathrm{Aa}}$ \\
\hline 30 & $2.78 \pm 0.11^{\mathrm{Ab}}$ & $2.81 \pm 0.07^{\mathrm{Ab}}$ & $3.18 \pm 0.05^{\mathrm{Aa}}$ & $4.39 \pm 0.53^{\mathrm{Bb}}$ \\
\hline 60 & $2.34 \pm 0.16^{\mathrm{Ac}}$ & $2.40 \pm 0.13^{\mathrm{Ac}}$ & NT & NT \\
\hline 90 & $1.57 \pm 0.39^{\mathrm{Ad}}$ & $1.79 \pm 0.21^{\mathrm{Ad}}$ & NT & NT \\
\hline
\end{tabular}

Table 2-3: Behavior of E. coli O157:H7 (log CFU/g) in Regular and Reduced Sodium Mozzarella Cheese Stored at 4 and $12^{\circ} \mathrm{C}$

\begin{tabular}{|c|c|c|c|c|}
\hline \multirow[b]{3}{*}{ Day } & \multicolumn{4}{|l|}{ Temperature } \\
\hline & $4{ }^{\circ} \mathrm{C}$ & & $12^{\circ} \mathrm{C}$ & \\
\hline & Regular Sodium & Reduced Sodium & Regular Sodium & Reduced Sodium \\
\hline 0 & $\begin{array}{l}2.16 \pm 0.44^{\mathrm{Aa}} \\
(4 / 4)\end{array}$ & $\begin{array}{l}2.45 \pm 0.31^{\text {Aa }} \\
(4 / 4)\end{array}$ & $\begin{array}{l}2.16 \pm 0.44^{\text {Aa }} \\
(4 / 4)\end{array}$ & $\begin{array}{l}2.45 \pm 0.31^{\text {Aa }} \\
(4 / 4)\end{array}$ \\
\hline 1 & $\begin{array}{l}2.59 \pm 0.51^{\mathrm{Aa}} \\
(4 / 4)\end{array}$ & $\begin{array}{l}2.61 \pm 0.32^{\text {Aa }} \\
(4 / 4)\end{array}$ & $\begin{array}{l}2.74 \pm 0.42^{\text {Aa }} \\
(4 / 4)\end{array}$ & $\begin{array}{l}2.80 \pm 0.40^{\text {Aa }} \\
(4 / 4)\end{array}$ \\
\hline 3 & NT & NT & $\begin{array}{l}2.60 \pm 0.27^{\text {Aa }} \\
(4 / 4)\end{array}$ & $\begin{array}{l}2.87 \pm 0.30^{\text {Aa }} \\
(4 / 4)\end{array}$ \\
\hline 7 & $\begin{array}{l}1.50 \pm 0.69^{\mathrm{Ab}} \\
(4 / 4)\end{array}$ & $\begin{array}{l}1.62 \pm 0.53^{\mathrm{Aa}} \\
(3 / 4)\end{array}$ & $\begin{array}{l}2.18 \pm 0.29^{\text {Aa }} \\
(4 / 4)\end{array}$ & $\begin{array}{l}2.17 \pm 0.61^{\mathrm{Aa}} \\
(4 / 4)\end{array}$ \\
\hline 15 & $\begin{array}{l}0.91 \pm 0.35^{\mathrm{Ac}} \\
(3 / 4)\end{array}$ & $\begin{array}{l}1.14 \pm 0.49^{\mathrm{Ac}} \\
(3 / 4)\end{array}$ & $\begin{array}{l}2.32 \pm 0.14^{\mathrm{Aa}} \\
(4 / 4)\end{array}$ & $\begin{array}{l}2.68 \pm 0.54 \\
(4 / 4)\end{array}$ \\
\hline 30 & $\begin{array}{l}0.59 \pm 0.23^{\mathrm{Ac}} \\
(3 / 4)\end{array}$ & $\begin{array}{l}<1^{\mathrm{Ac}} \\
(0 / 4)\end{array}$ & $\begin{array}{l}1.78 \pm 0.19^{\mathrm{Ab}} \\
(4 / 4)\end{array}$ & $\begin{array}{l}1.53 \pm 0.39^{\mathrm{Ab}} \\
(4 / 4)\end{array}$ \\
\hline 60 & $\begin{array}{l}0.57 \pm 0.14^{\mathrm{Ad}} \\
(1 / 4)\end{array}$ & $\begin{array}{l}<1^{A c} \\
(0 / 4)\end{array}$ & NT & NT \\
\hline 90 & $\begin{array}{l}<1^{\mathrm{Ad}} \\
(0 / 4)\end{array}$ & $\begin{array}{l}<1^{\mathrm{Ac}} \\
(0 / 4)\end{array}$ & NT & NT \\
\hline
\end{tabular}

${ }^{A}$ to ${ }^{B}$ Means with different capital letters in the same row are significantly different $(\mathrm{P}<0.05)$ between temperatures. ${ }^{\text {a to } b}$ Means with different lower case letters in the same column are significantly different $(\mathrm{P}<0.05)$. Numbers in parenthesis represent numbers of samples with viable counts. *NT: Samples were not tested at given temperature 
Table 2-4: Behavior of Salmonella (log CFU/g) in Regular and Reduced Sodium Mozzarella Cheese at 4 and $12^{\circ} \mathrm{C}$

\begin{tabular}{|c|c|c|c|c|}
\hline \multirow[b]{3}{*}{ Day } & \multicolumn{4}{|l|}{ Temperature } \\
\hline & $4^{\circ} \mathrm{C}$ & & $12^{\circ} \mathrm{C}$ & \\
\hline & Regular Sodium & Reduced Sodium & Regular Sodium & Reduced Sodium \\
\hline 0 & $\begin{array}{l}3.01 \pm 0.18^{\mathrm{Aa}} \\
(4 / 4)\end{array}$ & $\begin{array}{l}2.92 \pm 0.31^{\mathrm{Aa}} \\
(4 / 4)\end{array}$ & $\begin{array}{l}3.01 \pm 0.18^{\text {Аa }} \\
(4 / 4)\end{array}$ & $\begin{array}{l}2.92 \pm 0.31^{\text {Aa }} \\
(4 / 4)\end{array}$ \\
\hline 1 & $\begin{array}{l}2.94 \pm 0.27^{\mathrm{Aa}} \\
(4 / 4)\end{array}$ & $\begin{array}{l}2.90 \pm 0.16^{\mathrm{Aa}} \\
(4 / 4)\end{array}$ & $\begin{array}{l}2.89 \pm 0.24{ }^{\mathrm{Aa}} \\
(4 / 4)\end{array}$ & $\begin{array}{l}2.93 \pm 0.20 \text { Aa } \\
(4 / 4)\end{array}$ \\
\hline 3 & NT & NT & $\begin{array}{l}3.13 \pm 0.600^{\text {Aa }} \\
(4 / 4)\end{array}$ & $\begin{array}{l}2.99 \pm 0.55^{\text {Aa }} \\
(4 / 4)\end{array}$ \\
\hline 7 & $\begin{array}{l}2.43 \pm 0.49^{\mathrm{Aa}} \\
(4 / 4)\end{array}$ & $\begin{array}{l}2.06 \pm 0.46^{\mathrm{Aa}} \\
(4 / 4)\end{array}$ & $\begin{array}{l}2.81 \pm 0.15^{\text {Aa }} \\
(4 / 4)\end{array}$ & $\begin{array}{l}2.41 \pm 0.44^{\mathrm{Ab}} \\
(4 / 4)\end{array}$ \\
\hline 15 & $\begin{array}{l}1.78 \pm 0.52^{\mathrm{Ac}} \\
(4 / 4)\end{array}$ & $\begin{array}{l}1.56 \pm 1.21^{\mathrm{Ab}} \\
(4 / 4)\end{array}$ & $\begin{array}{l}2.22 \pm 0.21^{\mathrm{Ab}} \\
(4 / 4)\end{array}$ & $\begin{array}{l}2.16 \pm 0.48^{\mathrm{Ab}} \\
(4 / 4)\end{array}$ \\
\hline 30 & $\begin{array}{l}1.07 \pm 0.56^{\mathrm{Ad}} \\
(3 / 4)\end{array}$ & $\begin{array}{l}0.57 \pm 0.14^{\mathrm{Ac}} \\
(1 / 4)\end{array}$ & $\begin{array}{l}1.42 \pm 0.91^{\mathrm{Ac}} \\
(3 / 4)\end{array}$ & $\begin{array}{l}0.91 \pm 0.15^{\mathrm{Ac}} \\
(4 / 4)\end{array}$ \\
\hline 60 & $\begin{array}{l}<1^{\mathrm{Ad}} \\
(0 / 4)\end{array}$ & $\begin{array}{l}<1^{A c} \\
(0 / 4)\end{array}$ & NT & NT \\
\hline 90 & $\begin{array}{l}<1 \\
(0 / 4)\end{array}$ & $\begin{array}{l}<1^{\mathrm{Ac}} \\
(0 / 4)\end{array}$ & NT & NT \\
\hline
\end{tabular}

${ }^{A}$ to ${ }^{B}$ Means with different capital letters in the same row are significantly different $(\mathrm{P}<0.05)$ between temperatures. ${ }^{\mathrm{a} \text { to } \mathrm{b}}$ Means with different lower case letters in the same column are significantly different $(\mathrm{P}<0.05)$. Numbers in parenthesis represent numbers of samples with viable counts. *NT: Samples were not tested at given temperature

Populations of Salmonella decreased during storage in reduced and regular sodium Mozzarella cheese at 4 and $12{ }^{\circ} \mathrm{C}$ (Table 2-4). Salmonella showed a greater reduction at $4{ }^{\circ} \mathrm{C}$ than at $12{ }^{\circ} \mathrm{C}$. During storage at $4{ }^{\circ} \mathrm{C}$ Salmonella was not detected, while at $12{ }^{\circ} \mathrm{C}$ Salmonella was still present and slowly decreased in Mozzarella cheese after 30 days. Salmonella counts decreased below the detection limit resulting in $\mathrm{a} \geq 2.0$ and $\geq 2.1 \log \mathrm{CFU} / \mathrm{g}$ in reduced sodium Mozzarella cheese incubated at $4{ }^{\circ} \mathrm{C}$ after 60 days of storage. At $12{ }^{\circ} \mathrm{C}$, Salmonella population declined by $1.6 \log \mathrm{CFU} / \mathrm{g}$ and $2.0 \log \mathrm{CFU} / \mathrm{g}$ in reduced and regular sodium Mozzarella cheese by storage day 30, respectively (Table 2-4). 
Table 2-5: Behavior of Psychrotrophs (log CFU/g) in Regular and Reduced Sodium Mozzarella Cheese at 4 and $12^{\circ} \mathrm{C}$

\begin{tabular}{|c|c|c|c|c|}
\hline \multirow[b]{3}{*}{ Day } & \multicolumn{4}{|l|}{ Temperature } \\
\hline & $4{ }^{\circ} \mathrm{C}$ & & $12^{\circ} \mathrm{C}$ & \\
\hline & Regular Sodium & Reduced Sodium & Regular Sodium & Reduced Sodium \\
\hline 0 & $\begin{array}{l}1.89 \pm 0.28^{\mathrm{Aa}} \\
(4 / 4)\end{array}$ & $\begin{array}{l}<1^{\mathrm{Ba}} \\
(0 / 4)\end{array}$ & $\begin{array}{l}1.89 \pm 0.28^{\text {Aa }} \\
(4 / 4)\end{array}$ & $\begin{array}{l}<1^{\mathrm{Ba}} \\
(0 / 4)\end{array}$ \\
\hline 1 & $\begin{array}{l}1.86 \pm 0.86^{\mathrm{Aa}} \\
(4 / 4)\end{array}$ & $\begin{array}{l}0.64 \pm 0.27^{\mathrm{Aa}} \\
(1 / 4)\end{array}$ & $\begin{array}{l}2.80 \pm 0.56^{\mathrm{Ab}} \\
(4 / 4)\end{array}$ & $\begin{array}{l}0.78 \pm 0.39^{\mathrm{Bb}} \\
(2 / 4)\end{array}$ \\
\hline 3 & NT & NT & $\begin{array}{l}3.43 \pm 0.51^{\mathrm{Ab}} \\
(4 / 4)\end{array}$ & $\begin{array}{l}1.15 \pm 0.77^{\mathrm{Ba}} \\
(2 / 4)\end{array}$ \\
\hline 7 & $\begin{array}{l}3.66 \pm 0.40^{\mathrm{Ab}} \\
(4 / 4)\end{array}$ & $\begin{array}{l}2.40 \pm 0.78^{\mathrm{Ba}} \\
(1 / 4)\end{array}$ & $\begin{array}{l}4.56 \pm 0.31^{\mathrm{Ac}} \\
(4 / 4)\end{array}$ & $\begin{array}{l}2.40 \pm 0.78^{\mathrm{Bb}} \\
(4 / 4)\end{array}$ \\
\hline 15 & $\begin{array}{l}4.14 \pm 0.27^{\mathrm{Ab}} \\
(4 / 4)\end{array}$ & $\begin{array}{l}0.64 \pm 0.27^{\mathrm{Ba}} \\
(1 / 4)\end{array}$ & $\begin{array}{l}4.53 \pm 0.41^{\mathrm{Ac}} \\
(4 / 4)\end{array}$ & $\begin{array}{l}2.84 \pm 1.58^{\mathrm{Bc}} \\
(3 / 4)\end{array}$ \\
\hline 30 & $\begin{array}{l}5.10 \pm 0.23^{\mathrm{Ac}} \\
(4 / 4)\end{array}$ & $\begin{array}{l}1.13 \pm 0.85^{\mathrm{Bb}} \\
(2 / 4)\end{array}$ & $\begin{array}{l}5.08 \pm 0.29^{\mathrm{Ac}} \\
(4 / 4)\end{array}$ & $\begin{array}{l}3.79 \pm 0.51^{\mathrm{Ad}} \\
(4 / 4)\end{array}$ \\
\hline 60 & $\begin{array}{l}5.49 \pm 0.20^{\mathrm{Ac}} \\
(4 / 4)\end{array}$ & $\begin{array}{l}2.60 \pm 1.64^{\mathrm{Bb}} \\
(4 / 4)\end{array}$ & NT & NT \\
\hline 90 & $\begin{array}{l}5.44 \pm 0.11^{\mathrm{Ac}} \\
(4 / 4)\end{array}$ & $\begin{array}{l}4.64 \pm 0.35^{\mathrm{Ac}} \\
(4 / 4)\end{array}$ & NT & NT \\
\hline
\end{tabular}

${ }^{\mathrm{A} \text { to } \mathrm{B}}$ Means with different capital letters in the same row are significantly different $(\mathrm{P}<0.05$

$\mathrm{a}$ to $\mathrm{b}$ Means with different lower case letters in the same column are significantly different $(\mathrm{P}<0.05)$. Numbers in parenthesis represent numbers of samples with viable counts. *NT: Samples were not tested at given temperature

Psychrotroph counts increased in reduced and regular sodium Mozzarella cheese stored at 4 and $12^{\circ} \mathrm{C}$ (Table 2-5). Psychrotroph initial counts started below the detection limit for reduced sodium and at approximately $1.9 \mathrm{log} \mathrm{CFU} / \mathrm{g}$ in regular sodium Mozzarella cheese. However, at the end of the incubation time, psychrotrophs grew over $3.5 \mathrm{log} C F U / g$ in reduced and regular sodium Mozzarella cheese stored at 4 and $12^{\circ} \mathrm{C}$.

The population of coliforms remained less than $1.1 \log \mathrm{CFU} / \mathrm{g}$ (estimated) over the storage time in reduced and regular sodium Mozzarella cheese and there was no difference in reduced and regular cheeses stored at 4 and $12^{\circ} \mathrm{C}$ for 90 and 30 days, respectively (Table 2-6). The initial population of yeast was about $1 \mathrm{log}$ CFU/g higher in regular compared to reduced sodium Mozzarella cheese. During the incubation time, yeast significantly increased over $3.5 \log$ $\mathrm{CFU} / \mathrm{g}$ in reduced and regular sodium Mozzarella cheese stored at 4 and $12^{\circ} \mathrm{C}$. There was also a 
difference between the storage day and temperature effect on the population of yeast in Mozzarella cheese (Table 2-7).

Table 2-6: Behavior of Coliforms in $(\log \mathrm{CFU} / \mathrm{g})$ Regular and Reduced Sodium Mozzarella Cheese at 4 and $12^{\circ} \mathrm{C}$

\begin{tabular}{|c|c|c|c|c|}
\hline \multirow[b]{3}{*}{ Day } & \multicolumn{4}{|l|}{ Temperature } \\
\hline & \multicolumn{2}{|l|}{$4^{\circ} \mathrm{C}$} & \multicolumn{2}{|l|}{$12^{\circ} \mathrm{C}$} \\
\hline & Regular Sodium & Reduced Sodium & Regular Sodium & Reduced Sodium \\
\hline 5 & $0.75 \pm 0.50^{\mathrm{Aa}}$ & $<1^{\mathrm{Aa}}$ & $0.75 \pm 0.50^{\mathrm{Aa}}$ & $<1^{\mathrm{Aa}}$ \\
\hline U & $(1 / 4)$ & $(0 / 4)$ & $(1 / 4)$ & $(0 / 4)$ \\
\hline 1 & $0.68 \pm 0.35^{\mathrm{Aa}}$ & $<1^{\text {Áa }}$ & $0.57 \pm 0.14^{\mathrm{Aa}}$ & $<1^{\mathrm{Aa}}$ \\
\hline 1 & $(1 / 4)$ & $(0 / 4)$ & $(1 / 4)$ & $(0 / 4)$ \\
\hline 3 & NT & NT & $<1^{\text {Aa }}$ & $<1^{\mathrm{Aa}}$ \\
\hline & $<1^{\text {Aa }}$ & $<1^{\mathrm{Aa}}$ & $1.13 \pm 1.00^{\mathrm{Aa}}$ & $1.22 \pm 0.53 \mathrm{Aa}$ \\
\hline 7 & $(0 / 4)$ & $(0 / 4)$ & $(4 / 4)$ & $(3 / 4)$ \\
\hline 15 & $0.85 \pm 0.41^{\mathrm{Aa}}$ & $0.99 \pm 0.57^{\mathrm{Aa}}$ & $<1 \mathrm{Aa}$ & $<1 \mathrm{Aa}$ \\
\hline 15 & $(1 / 4)$ & $(2 / 4)$ & $(0 / 4)$ & $(0 / 4)$ \\
\hline 30 & $<1 \mathrm{Aa}$ & $<1^{\text {Áa }}$ & $1.01 \pm 0.85^{\mathrm{Aa}}$ & $0.88 \pm 0.75^{\mathrm{Aa}}$ \\
\hline 30 & $(0 / 4)$ & $(0 / 4)$ & $(2 / 4)$ & $(1 / 4)$ \\
\hline 60 & $\begin{array}{l}0.64 \pm 0.16^{\mathrm{Aa}} \\
(2 / 4)\end{array}$ & $\begin{array}{l}0.64 \pm 0.16^{A a} \\
(2 / 4)\end{array}$ & NT & NT \\
\hline 90 & $\begin{array}{l}0.90 \pm 0.51^{\mathrm{Aa}} \\
(2 / 4)\end{array}$ & $\begin{array}{l}1.26 \pm 0.74^{\mathrm{Aa}} \\
(3 / 4)\end{array}$ & NT & NT \\
\hline
\end{tabular}

A to B Means with different capital letters in the same row are significantly different $(\mathrm{P}<0.05)$ between temperatures. ${ }^{\mathrm{a}}$ to $\mathrm{b}$ Means with different lower case letters in the same column are significantly different $(\mathrm{P}<0.05)$. Numbers in parenthesis indicate numbers of samples with viable counts. *NT: Samples were not tested at given temperature

Mold counts were significantly different between temperatures at the end of the incubation period, but not between treatments (Table 2-8). Cheeses had initial mold counts of approximately $0.5 \log \mathrm{CFU} / \mathrm{g}$. However, by the end of storage time at $4^{\circ} \mathrm{C}$, mold counts were higher in reduced sodium than in regular sodium Mozzarella cheese by approximately $4 \log$ CFU/g. However, the mold population was no different between treatments in cheeses stored at $12{ }^{\circ} \mathrm{C}$. 
Table 2-7: Behavior of yeast (log CFU/g) in Regular and Reduced Sodium Mozzarella Cheese Stored at 4 and $12^{\circ} \mathrm{C}$

\begin{tabular}{|c|c|c|c|c|}
\hline \multirow[b]{3}{*}{ Day } & \multicolumn{4}{|l|}{ Temperature } \\
\hline & $4^{\circ} \mathrm{C}$ & & $12^{\circ} \mathrm{C}$ & \\
\hline & Regular Sodium & Reduced Sodium & Regular Sodium & Reduced Sodium \\
\hline 0 & $\begin{array}{l}1.72 \pm 0.45^{\mathrm{Aa}} \\
(4 / 4)\end{array}$ & $\begin{array}{l}<1^{\text {Aa }} \\
(0 / 4)\end{array}$ & $\begin{array}{l}1.72 \pm 0.45^{\mathrm{Aa}} \\
(4 / 4)\end{array}$ & $\begin{array}{l}<1^{\mathrm{Aa}} \\
(0 / 4)\end{array}$ \\
\hline 1 & $\begin{array}{l}1.18 \pm 0.64 \\
(3 / 4)\end{array}$ & $\begin{array}{l}<1 \\
(0 / 4)\end{array}$ & $\begin{array}{l}2.30 \pm 0.90^{\mathrm{Aa}} \\
(4 / 4)\end{array}$ & $\begin{array}{l}<1 \\
(0 / 4)\end{array}$ \\
\hline 3 & NT & NT & $\begin{array}{l}2.58 \pm 0.63 \text { Aa } \\
(4 / 4)\end{array}$ & $\begin{array}{l}1.49 \pm 1.14 \\
(2 / 4)\end{array}$ \\
\hline 7 & $\begin{array}{l}2.32 \pm 0.74 \\
(4 / 4)\end{array}$ & $\begin{array}{l}<1 \mathrm{Ba} \\
(0 / 4)\end{array}$ & $\begin{array}{l}3.78 \pm 0.21^{\mathrm{Ab}} \\
(4 / 4)\end{array}$ & $\begin{array}{l}2.18 \pm 0.99^{\mathrm{Aa}} \\
(4 / 4)\end{array}$ \\
\hline 15 & $\begin{array}{l}3.16 \pm 0.14^{\mathrm{Ab}} \\
(4 / 4)\end{array}$ & $\begin{array}{l}0.72 \pm 0.46^{\mathrm{Ba}} \\
(1 / 4)\end{array}$ & $\begin{array}{l}4.22 \pm 0.81^{\mathrm{Ac}} \\
(4 / 4)\end{array}$ & $\begin{array}{l}2.88 \pm 1.59 \\
(3 / 4)\end{array}$ \\
\hline 30 & $\begin{array}{l}3.44 \pm 0.44^{\mathrm{Ab}} \\
(4 / 4)\end{array}$ & $\begin{array}{l}1.24 \pm 0.96^{\mathrm{Bb}} \\
(3 / 4)\end{array}$ & $\begin{array}{l}2.03 \pm 1.15^{\mathrm{Aa}} \\
(3 / 4)\end{array}$ & $\begin{array}{l}2.20 \pm 1.99^{\mathrm{Aa}} \\
(2 / 4)\end{array}$ \\
\hline 60 & $\begin{array}{l}5.00 \pm 0.52^{\mathrm{Ac}} \\
(4 / 4)\end{array}$ & $\begin{array}{l}2.47 \pm 1.83^{\mathrm{Bb}} \\
(3 / 4)\end{array}$ & NT & NT \\
\hline 90 & $\begin{array}{l}4.80 \pm 0.27^{\mathrm{Ac}} \\
(4 / 4)\end{array}$ & $\begin{array}{l}4.39 \pm 0.53^{\mathrm{Ac}} \\
(4 / 4)\end{array}$ & NT & NT \\
\hline
\end{tabular}

A to ${ }^{B}$ Means with different capital letters in the same row are significantly different $(\mathrm{P}<0.05)$ between temperatures. ${ }^{\mathrm{a} \text { to } \mathrm{b}}$ Means with different lower case letters in the same column are significantly different $(\mathrm{P}<0.05)$. Numbers in parenthesis represent numbers of samples with viable counts. *NT: Samples were not tested at given temperature

The initial water activities were different at the beginning of the experiment for Mozzarella cheese stored at 4 and $12{ }^{\circ} \mathrm{C}$ over 30 days and 90 days, respectively. However, after storage day 1 , the water activity leveled off between treatments during storage temperatures. Significant differences in water activity were observed between treatment $(p<0.05)$-reduced and regular sodium-Mozzarella cheeses stored at $12{ }^{\circ} \mathrm{C}$ over 30 days. On average, reduced sodium cheeses had a significantly higher water activity than regular sodium cheeses, regardless of storage temperatures, with an average of 0.9705 and 0.9644 , respectively (Table 2-9). The water activity for reduced and regular sodium Mozzarella cheese was maintained during the incubation period. There was no significant difference in $\mathrm{pH}$ between reduced and regular sodium Mozzarella cheeses stored at 4 and $12{ }^{\circ} \mathrm{C}$ at either 90 or 30 days (Table 2-10). 
Table 2-8: Water Activity of Regular and Reduced Sodium Mozzarella Cheese Stored at 4 and $12^{\circ} \mathrm{C}$

\begin{tabular}{|c|c|c|c|c|}
\hline \multirow[b]{3}{*}{ Day } & \multicolumn{4}{|l|}{ Temperature } \\
\hline & $4{ }^{\circ} \mathrm{C}$ & & $12{ }^{\circ} \mathrm{C}$ & \\
\hline & Regular Sodium & Reduced Sodium & Regular Sodium & Reduced Sodium \\
\hline 0 & $0.9640 \pm 0.0029^{\mathrm{Aa}}$ & $0.9714 \pm 0.0007^{\mathrm{Ba}}$ & $0.9640 \pm 0.0024^{\mathrm{Aa}}$ & $0.9714 \pm 0.0007^{\mathrm{Ba}}$ \\
\hline 1 & $0.9666 \pm 0.049^{\mathrm{A}}$ & $0.9719 \pm 0.0020^{\mathrm{Aa}}$ & $0.9639 \pm 0.0051^{\mathrm{Aa}}$ & $0.9661 \pm 0.0033^{\mathrm{Ab}}$ \\
\hline 3 & NT & NT & $0.9646 \pm 0.0021^{\mathrm{Aa}}$ & $0.9672 \pm 0.0043^{\mathrm{Aa}}$ \\
\hline 7 & $0.9656 \pm 0.0064^{\mathrm{Aa}}$ & $0.9680 \pm 0.0072^{\mathrm{Aa}}$ & $0.9602 \pm 0.0040^{\mathrm{Ab}}$ & $0.9684 \pm 0.0018^{\mathrm{Bb}}$ \\
\hline 15 & $0.9638 \pm 0.0053^{\mathrm{Aa}}$ & $0.9783 \pm 0.0110^{\mathrm{Bb}}$ & $0.9608 \pm 0.0025^{\mathrm{Ab}}$ & $0.9742 \pm 0.0032^{\mathrm{Ba}}$ \\
\hline 30 & $0.9665 \pm 0.0007^{\mathrm{Aa}}$ & $0.96202 \pm 0.0010^{\mathrm{Aa}}$ & $0.9664 \pm 0.0038^{\mathrm{Aa}}$ & $0.9702 \pm 0.0027^{\mathrm{Ba}}$ \\
\hline 60 & $0.9673 \pm 0.0023^{\mathrm{Aa}}$ & $0.9712 \pm 0.0032^{\mathrm{Aa}}$ & NT & NT \\
\hline 90 & $0.9637 \pm 0.0026^{\mathrm{Aa}}$ & $0.9680 \pm 0.0023^{\mathrm{Aa}}$ & NT & NT \\
\hline
\end{tabular}

Table 2-9 : Behavior of Mold (log CFU/g) in Regular and Reduced Sodium Mozzarella Cheese at stored at 4 and $12^{\circ} \mathrm{C}$

\begin{tabular}{|c|c|c|c|c|}
\hline \multirow[b]{3}{*}{ Day } & \multicolumn{4}{|l|}{ Temperature } \\
\hline & $4^{\circ} \mathrm{C}$ & & $12^{\circ} \mathrm{C}$ & \\
\hline & Regular Sodium & Reduced Sodium & Regular Sodium & Reduced Sodium \\
\hline 0 & $\begin{array}{l}0.57 \pm 0.14^{\mathrm{Aa}} \\
(1 / 4)\end{array}$ & $\begin{array}{l}1.04 \pm 1.10^{\mathrm{Aa}} \\
(1 / 4)\end{array}$ & $\begin{array}{l}0.57 \pm 0.14^{\mathrm{Aa}} \\
(1 / 4)\end{array}$ & $\begin{array}{l}1.04 \pm 1.10^{\mathrm{Aa}} \\
(1 / 4)\end{array}$ \\
\hline 1 & $\begin{array}{l}0.78 \pm 0.39^{\mathrm{Aa}} \\
(2 / 4)\end{array}$ & $\begin{array}{l}<1 \text { Aa } \\
(4 / 4)\end{array}$ & $\begin{array}{l}0.57 \pm 0.14^{\mathrm{Aa}} \\
(1 / 4)\end{array}$ & $\begin{array}{l}<1 \\
(0 / 4)\end{array}$ \\
\hline 3 & NT & NT & $\begin{array}{l}1.07 \pm 0.49^{\mathrm{Aa}} \\
(3 / 4)\end{array}$ & $\begin{array}{l}0.57 \pm 0.14 \\
(1 / 4)\end{array}$ \\
\hline 7 & $\begin{array}{l}0.95 \pm 0.72^{\mathrm{Aa}} \\
(2 / 4)\end{array}$ & $\begin{array}{l}0.92 \pm 0.84^{\mathrm{Aa}} \\
(1 / 4)\end{array}$ & $\begin{array}{l}2.44 \pm 0.50^{\mathrm{Ab}} \\
(4 / 4)\end{array}$ & $\begin{array}{l}0.64 \pm 0.27^{\mathrm{Aa}} \\
(1 / 1)\end{array}$ \\
\hline 15 & $\begin{array}{l}0.82 \pm 0.64^{\mathrm{Aa}} \\
(1 / 4)\end{array}$ & $\begin{array}{l}<1 \text { Aa } \\
(0 / 4)\end{array}$ & $\begin{array}{l}1.58 \pm 1.24^{\mathrm{Ab}} \\
(2 / 4)\end{array}$ & $\begin{array}{l}1.74 \pm 1.44 \\
(2 / 4)\end{array}$ \\
\hline 30 & $\begin{array}{l}0.88 \pm 0.75^{\mathrm{Aa}} \\
(1 / 4)\end{array}$ & $\begin{array}{l}0.81 \pm 0.62^{\mathrm{Aa}} \\
(1 / 4)\end{array}$ & $\begin{array}{l}2.22 \pm 1.99^{\mathrm{Ab}} \\
(2 / 4)\end{array}$ & $\begin{array}{l}3.87 \pm 2.27^{\mathrm{Ab}} \\
(3 / 4)\end{array}$ \\
\hline 60 & $\begin{array}{l}2.88 \pm 1.90^{\mathrm{Ab}} \\
(3 / 4)\end{array}$ & $\begin{array}{l}0.75 \pm 0.50 \text { Aa } \\
(1 / 4)\end{array}$ & NT & NT \\
\hline 90 & $\begin{array}{l}4.37 \pm 1.06^{\mathrm{Ab}} \\
(4 / 4)\end{array}$ & $\begin{array}{l}<1^{\mathrm{Ba}} \\
(4 / 4)\end{array}$ & NT & NT \\
\hline
\end{tabular}

A to B Means with different capital letters in the same row are significantly different $(\mathrm{P}<0.05)$ between temperatures. ${ }^{\mathrm{a} \text { to } \mathrm{b}}$ Means with different lower case letters in the same column are significantly different $(\mathrm{P}<0.05)$. Numbers in parenthesis represent numbers of samples with viable counts. *NT: Samples were not tested at given temperature. 
Table 2-10: Water Activity of Regular and Reduced Sodium Mozzarella Cheese Stored at 4 and $12^{\circ} \mathrm{C}$

\begin{tabular}{|c|c|c|c|c|}
\hline \multirow[b]{3}{*}{ Day } & \multicolumn{4}{|l|}{ Temperature } \\
\hline & $4^{\circ} \mathrm{C}$ & & $12{ }^{\circ} \mathrm{C}$ & \\
\hline & Regular Sodium & Reduced Sodium & Regular Sodium & Reduced Sodium \\
\hline 0 & $0.9640 \pm 0.0029^{\mathrm{Aa}}$ & $0.9714 \pm 0.0007^{\mathrm{Ba}}$ & $0.9640 \pm 0.0024^{\mathrm{Aa}}$ & $0.9714 \pm 0.0007^{\mathrm{Ba}}$ \\
\hline 1 & $0.9666 \pm 0.049^{\mathrm{A}}$ & $0.9719 \pm 0.0020^{\mathrm{Aa}}$ & $0.9639 \pm 0.0051^{\mathrm{Aa}}$ & $0.9661 \pm 0.0033^{\mathrm{Ab}}$ \\
\hline 3 & NT & NT & $0.9646 \pm 0.0021^{\mathrm{Aa}}$ & $0.9672 \pm 0.0043^{\mathrm{Aa}}$ \\
\hline 7 & $0.9656 \pm 0.0064^{\mathrm{Aa}}$ & $0.9680 \pm 0.0072^{\mathrm{Aa}}$ & $0.9602 \pm 0.0040^{\mathrm{Ab}}$ & $0.9684 \pm 0.0018^{\mathrm{Bb}}$ \\
\hline 15 & $0.9638 \pm 0.0053^{\mathrm{Aa}}$ & $0.9783 \pm 0.0110^{\mathrm{Bb}}$ & $0.9608 \pm 0.0025^{\mathrm{Ab}}$ & $0.9742 \pm 0.0032^{\mathrm{Ba}}$ \\
\hline 30 & $0.9665 \pm 0.0007^{\mathrm{Aa}}$ & $0.96202 \pm 0.0010^{\mathrm{Aa}}$ & $0.9664 \pm 0.0038^{\mathrm{Aa}}$ & $0.9702 \pm 0.0027^{\mathrm{Ba}}$ \\
\hline 60 & $0.9673 \pm 0.0023^{\mathrm{Aa}}$ & $0.9712 \pm 0.0032^{\mathrm{Aa}}$ & NT & NT \\
\hline 90 & $0.9637 \pm 0.0026^{\mathrm{Aa}}$ & $0.9680 \pm 0.0023^{\mathrm{Aa}}$ & NT & NT \\
\hline
\end{tabular}

${ }^{A \text { to } B}$ Means with different capital letters in the same row are significantly different $(\mathrm{p}<0.05)$.

$a$ to $b$ Means with different lower case letters in the same column are significantly different $(\mathrm{p}<0.05)$. *NT: Not tested at given temperature

Table 2-11: pH of Regular and Reduced Sodium Mozzarella Cheese Stored at 4 and $12^{\circ} \mathrm{C}$

\begin{tabular}{|c|c|c|c|c|}
\hline \multirow[b]{3}{*}{ Day } & \multicolumn{4}{|l|}{ Temperature } \\
\hline & \multicolumn{2}{|l|}{$4{ }^{\circ} \mathrm{C}$} & \multicolumn{2}{|l|}{$12{ }^{\circ} \mathrm{C}$} \\
\hline & Regular Sodium & Reduced Sodium & Regular Sodium & Reduced Sodium \\
\hline 0 & $5.43 \pm 0.03^{\mathrm{Aa}}$ & $5.56 \pm 0.04^{\mathrm{Aa}}$ & $5.43 \pm 0.03^{\mathrm{Aa}}$ & $5.56 \pm 0.04^{\mathrm{Aa}}$ \\
\hline 1 & $5.40 \pm 0.18^{\mathrm{Aa}}$ & $5.44 \pm 0.14^{\mathrm{Aa}}$ & $5.49 \pm 0.04^{\mathrm{Aa}}$ & $5.40 \pm 0.08^{\mathrm{Aa}}$ \\
\hline 3 & NT & NT & $5.49 \pm 0.10^{\mathrm{Aa}}$ & $5.42 \pm 0.12^{\mathrm{Aa}}$ \\
\hline 7 & $5.52 \pm 0.11^{\mathrm{Aa}}$ & $5.55 \pm 0.09^{\mathrm{Aa}}$ & $5.40 \pm 0.26^{\mathrm{Aa}}$ & $5.54 \pm 0.11^{\mathrm{Aa}}$ \\
\hline 15 & $5.46 \pm 0.05^{\mathrm{Aa}}$ & $5.45 \pm 0.08^{\mathrm{Aa}}$ & $5.42 \pm 0.11^{\mathrm{Aa}}$ & $5.43 \pm 0.08^{\mathrm{Aa}}$ \\
\hline 30 & $5.56 \pm 0.05^{\text {Аа }}$ & $5.57 \pm 0.03^{\mathrm{Aa}}$ & $5.56 \pm 0.04^{\mathrm{Aa}}$ & $5.52 \pm 0.04^{\text {Аа }}$ \\
\hline 60 & $5.53 \pm 0.02^{\mathrm{Aa}}$ & $5.55 \pm 0.01^{\mathrm{Aa}}$ & NT & NT \\
\hline 90 & $5.54 \pm 0.02^{\mathrm{Aa}}$ & $5.55 \pm 0.03^{\mathrm{Aa}}$ & NT & NT \\
\hline
\end{tabular}




\subsection{Discussion}

Listeria monocytogenes counts decreased during storage at $4^{\circ} \mathrm{C}$ by approximately $1.5 \log$ $\mathrm{CFU} / \mathrm{g}$ in regular and reduced sodium Mozzarella cheese. In other studies, L. monocytogenes also remained present and slowly decreased in hard cheeses regardless of the salt concentration at refrigeration temperatures. For instance, the salt concentration was not involved in the growth of L. monocytogenes in Cheddar cheese gradually decreased by 0.54 to $0.69,0.66$ to $0.83,0.48$ to $0.14 \log \mathrm{CFU} / \mathrm{g}$ in low and standard salt Cheddar cheese $(0.7 \%$ and $1.8 \%)$, with a $\mathrm{pH}$ similar to this study, stored at 4,10 , and $21{ }^{\circ} \mathrm{C}$, respectively (Shrestha et al., 2011a). However, the salt concentration and cheese type used differed from the present study, which caused a significantly higher reduction at higher temperatures. At $12^{\circ} \mathrm{C}$, the L. monocytogenes population remained the same and increased by approximately $1 \log$ CFU/g in reduced and regular sodium Mozzarella cheese by storage day 30 in this experiment.

Similarly, in other studies, L. monocytogenes gradually decreased with lower refrigeration temperatures, but increased or remained stable at higher temperatures. For example, Finazzi et al. (2011) also found that at $5{ }^{\circ} \mathrm{C}$, L. monocytogenes counts in packaged water buffalo Mozzarella cheese (salt content unknown) decreased approximately $1 \log$ CFU/g over time, while counts increased about $2 \log \mathrm{CFU} / \mathrm{g}$ in cheese stored at 10 and $21^{\circ} \mathrm{C}$ after 22 and 9 days, respectively. L. monocytogenes in cheeses have reportedly grown at refrigeration and abusive temperatures in other studies, suggesting this difference of growth may be due to a component of cheese other than salt, such as $\mathrm{pH}$, water activity and moisture content or a combination of all. For example, L. monocytogenes in Queso Blanco cheese made with 2.32 (g/100 salt) increased after 17 days and 8 days of storage at 5 and $10{ }^{\circ} \mathrm{C}$, respectively (Uhlich et al., 2006). Inhibition or slower growth of L. monocytogenes population in Queso Blanco did not depend only on storage at the proper temperature, but was due to the cheese formulation, particularly its acidity. Queso Fresco has a higher pH (6.8) than the Mozzarella cheese used in this study (5.5), therefore, the 
reduction of L. monocytogenes seen at $4^{\circ} \mathrm{C}$ in regular and reduced Mozzarella cheese could be attributed to the $\mathrm{pH}$ and storage temperature.

In the present study, L. monocytogenes may have decreased during storage at lower temperatures $\left(4^{\circ} \mathrm{C}\right)$ because low temperatures prolong the lag and stationary phase rates of pathogenic bacteria affecting the bacterial growth. Conversely, storage at higher temperatures $\left(12^{\circ} \mathrm{C}\right)$ may enhance bacterial growth (Uhlich et al., 2006). These results differ from the aforementioned studies because the cheese matrix for Mozzarella cheese is different than Cheddar and Queso Fresco cheese. A few differences of these cheeses matrixes are that Cheddar cheese is a hard cheese with a moisture content of $\leq 40 \%$ made with mesophilic starters cultures. Cheddar cheese is usually ripened for 3 to 24 months at $6-10{ }^{\circ} \mathrm{C}$. Queso Fresco is a fresh cheese generally made by acidifiers with/without starter culture, and a moisture content of $46-51 \%$. In contrast, Mozzarella cheese is a soft/semi soft cheese with a moisture content of $\geq 52 \%$ made with thermophilic starters cultures (Fox et al., 2004).

In this study, Salmonella and E. coli $\mathrm{O} 157: \mathrm{H} 7$ populations decreased below the detection limit $(<1 \log \mathrm{CFU} / \mathrm{g})$ in regular and reduced sodium cheese stored at $4{ }^{\circ} \mathrm{C}$ over 90 days, but after 30 days of storage at $12{ }^{\circ} \mathrm{C}$, populations were still viable. Govaris et al. (2001) also found that $E$. coli $\mathrm{O} 157: \mathrm{H} 7$ decreased $2.5 \log \mathrm{CFU} / \mathrm{g}$ at lower temperatures $\left(2^{\circ} \mathrm{C}\right)$, but it could survive and grew around $1.3 \log \mathrm{CFU} / \mathrm{g}$ at higher temperatures $\left(12^{\circ} \mathrm{C}\right)$ in whey cheeses with a salt concentration of $0.5,1.4$, and $1.9 \%$, and a $\mathrm{pH}$ range from 5.2 to 6.3 . They conclude that E.coli might have grown at $12^{\circ} \mathrm{C}$ due to this pathogen's optimal growth which occurs at warmer temperatures $\left(37^{\circ} \mathrm{C}\right)$. Similarly, the E. coli population in Paneer cheese made with $5.7 \mathrm{pH}$ with a 55\% moisture content and unknown salt content stored at 4 or $8{ }^{\circ} \mathrm{C}$ was stable and temperature did not have an impact on their growth or survival (Wahi, Bansal, Ghosh, \& Ganguli, 2006). Changes in the population of Salmonella have also been reported by other studies of cheeses with salt concentrations that were lower than this study. Shrestha et al. (2011) found that the population of Salmonella 
gradually decreased over time at storage temperatures of 4,10 , and $21{ }^{\circ} \mathrm{C}$ in Cheddar cheese with salt concentrations $(0.7 \%$ and $1.8 \%)$ at different $\mathrm{pH}$ ranges (5.1 to 5.5). Hargrove, McDonough, and Mattingly (1969) found that salt did not enhance the inhibition of Salmonella in Cheddar or Colby cheeses made with a salt content of $1.8,2.01$, and $2.63 \%$, a lactic starter of $0.5,1,2$, and $3 \%$, and a final $\mathrm{pH}$ of 5.0,5.2, 5.4, and 5.7. Only $\mathrm{pH}$ and starter cultures were directly related to Salmonella inhibition.

In the present study, the concentration of salt may have a limited impact on the growth/survival of L. monocytogenes, E. coli O157:H7 and Salmonella in reduced and regular sodium Mozzarella cheese because the salt concentration of this cheese was less than $2.5 \%$. Escherichia coli and Salmonella growth are affected when the salt content in cheese is greater than 2.5 to $3 \%$ even under higher temperature and $\mathrm{pH}$ conditions (Sutherland, Bayliss, \& Braxton, 1995). Salt tolerance in foods for E. coli $\mathrm{O} 157: \mathrm{H} 7$ is up to $6.5 \%$ and for Salmonella is $8 \%$, while L. monocytogenes is a more resilient food organism which can survive under stress conditions, and its salt tolerance is up to 10\% (U.S. Food and Drug Administration, 2011;Gardan, Cossart, Consortium, \& Labadie, 2003). Reduction of the population of L. monocytogenes, E.coli O157:H7 and Salmonella might be due to the interaction and action between $\mathrm{NaCl}, \mathrm{pH}$, and lactic acid produced by starter bacteria (Oh et al., 2014; Hargrove, McDonough, and Mattingly, 1989). Ingham et al. (2000) reported that the food composition, $\mathrm{pH}$, and low temperatures had an effect on the survival of Salmonella and E. coli $\mathrm{O} 157: \mathrm{H} 7$ in a brine model made with a significantly higher salt content of 23\% (w/v) brine with and without $2 \%(\mathrm{v} / \mathrm{v})$ added whey, and at a $\mathrm{pH} 5.7$ stored at 8 and $15^{\circ} \mathrm{C}$ which caused a reduction of between 1-2 log CFU/g. In this study, acidity, water activity, moisture, starter cultures, and storage temperature in reduced in regular sodium Mozzarella cheese could have influenced the reduction of L. monocytogenes, Salmonella and E. coli $\mathrm{O} 157: \mathrm{H} 7$ as was seen in aforementioned studies. However, neither the lactic acid bacterial 
load nor lactic acid were measured, which makes it difficult to predict whether its actions had an effect on the reduction of pathogenic bacteria in this study.

The initial level of spoilage bacteria was different between cheeses and the results obtained could not conclusively determine the differences between temperatures or cheese types. For instance, the psychrotroph counts started with a higher inoculum for regular than reduced sodium Mozzarella cheese, and there was better growth of the population of psychrothrophs at the end of storage time in regular compared to reduced sodium Mozzarella cheese. High counts of psychrotroph bacteria over time might be due to a slight contamination during the handling of Mozzarella cheese, and the moisture content, water activity, $\mathrm{pH}$, and storage temperature could have helped with the reproduction of those spoilage bacteria (McSweeney, 2007).

The population of coliforms in reduced and regular sodium Mozzarella cheese remained less than $1.1 \log$ CFU/g (estimated), and there was no significant difference in reduced or regular cheeses stored at 4 and $12^{\circ} \mathrm{C}$ for 90 and 30 days, respectively. The low amount of coliform counts supported the fact that the assayed cheeses were produced and handled under good hygiene control practices (Ledenbach and Marshall, 2009).

There was no significant difference in the population of yeast between reduced and regular sodium Mozzarella cheese; however, there was a significant difference between the storage day and temperature effect. The population of yeast increased during storage time in reduced and regular sodium Mozzarella. The yeast population might have grown due its preference for the low moisture and $\mathrm{pH}$ of reduced and regular Mozzarella cheese. The higher counts of yeast present in regular sodium stored at $4{ }^{\circ} \mathrm{C}$ more so than reduced sodium Mozzarella cheeses stored at $12^{\circ} \mathrm{C}$ might be due to the preference of yeast for high salt levels and low temperatures, which causes its prompt growth (Sulieman, Ali, and Razig, 2013; Fleet and Mian, 1987). Fungal spoilage of reduced and regular Mozzarella cheese could be attributed to a predisposition for fungal spoilage to grow into soft cheeses and at low $\mathrm{pH}$ (Banjara, Suhr, Hallen- 
Adams, 2014). Also, the population of yeast and mold might have increased in the samples if some samples were not vacuum sealed properly, and inadequate handling of the cheeses might have led to air access.

For the physio-chemical analysis, the water activity for reduced and regular sodium Mozzarella cheese did not change during the incubation period of 90 and 30 days at either 4 or 12 ${ }^{\circ} \mathrm{C}$. Reduced sodium cheeses exhibited a higher water activity; since water activity is correlated with the amount of salt, high levels of salt in cheese cause salt and water to bind thereby lowering the water activity (Fox, 2004). During the experiment, the $\mathrm{pH}$ was no different between treatment or storage temperatures, and the $\mathrm{pH}$ was maintained within the acceptable range of approximately 5.0 to 5.6 for Mozzarella cheese (USA Patent No. US8628810 B2, 2014).

\subsection{Conclusion}

This research has demonstrated that the tested salt concentrations does not affect microbial growth in Mozzarella cheese, except when L. monocytogenes is present during storage at $12^{\circ} \mathrm{C}$. Herein, the populations of Salmonella and E. coli $\mathrm{O} 157: \mathrm{H} 7$ showed no difference in reduced and regular sodium Mozzarella cheese. However, there was a difference in the population of L. monocytogenes for regular and reduced sodium incubated at 4 and $12^{\circ} \mathrm{C}$. Moreover, there was no statistical difference in the $\mathrm{pH}$, coliforms, yeast or mold counts, but there was a difference for psychrotroph counts between regular and reduced sodium Mozzarella cheese stored at 4 and $12^{\circ} \mathrm{C}$ over 90 and 30 days. Although pathogenic bacteria did not grow, survival is still a possibility. The present work offers more understanding about the role of sodium in the microbial growth of Mozzarella cheeses. This knowledge will help to develop reduced sodium dairy products with high microbial stability and will serve to promote a healthier food intake for cheese consumers. 


\section{CHAPTER 3: REDUCTION OF LISTERIA INNOCUA ON QUESO FRESCOAND MOZZARELLA CHEESE USING SUPERCRITICAL FLUID EXTRACTION WITH $\mathrm{CO}_{2}$}

\subsection{Introduction}

Contamination of dairy products with Listeria monocytogenes continues to challenge the dairy industry. In 2013, this pathogen cost the United States up to $\$ 2.8$ billion in medical costs alone, excluding the cost to the food industries and agencies responding to the outbreak (Flynn, 2014). In the period from 1998 to 2001, approximately 96 outbreaks were caused by the consumption of cheese and dairy products were rated as the second leading cause of foodborne illness, second to leafy products. Cheeses, including Mozzarella cheese and Queso Fresco have been involved in such cases. Listeria monocytogenes in Queso Fresco is the most common cause of recalls and outbreaks.

Most contamination from L. monocytogenes occurs during post-processing of dairy products. To minimize post-process contamination, antimicrobials have been used to reduce the growth of L. monocytogenes in cheeses. Alternatives to food additives are desired by the consumer and novel physical treatments, such as supercritical fluid extraction with $\mathrm{CO}_{2}$ (SFE) have been investigated as a strategy to reduce the microbial population and enhance the safety of foods. SFE involves a separation of a particular substance from a product and is combined with supercritical fluid to form a mobile phase. This mobile phase utilizes pressure and temperature at, or higher than, the critical point to improve the mobile phase's solvating power, whereby at the critical point, gas and liquid phases merge to form a supercritical phase (Palmer \& Ting, 1995). A change in pressure or temperature enhances the control of the fluid density, diffusivity, dielectric constant, and viscosity. A supercritical fluid is characterized by a high diffusion rate, reduced viscosity, and increased surface tension. These characteristics help to improve its mass transfer by effusion of the fluid though solids (Palmer \& Ting, 1995; Sihvonen, Järvenpää, Hietaniemi, \& Huopalahti, 1999). 
During the process of SFE, first, a low pressure causes a rise in the solute vapor. Then, both temperature and pressure rise to cause an increase in the solute vapor pressure and, in compensation for the reduction in solvent density, causes a higher solubility. The surface area, sample size, moisture content, and interaction of the product with the fluid are important parameters that can affect the solubility and the results of the supercritical fluid (Sairam, Ghosh, Jena, Rao, \& Banji, 2012).

Carbon dioxide, nitrogen oxide, ammonia, ethane, propane, ethylene, and Freon 13 are typical gases used for critical fluid extraction (Rozzi \& Singh, 2002). Carbon dioxide $\left(\mathrm{CO}_{2}\right)$ is most commonly used in the food industry, as it is generally recognized as safe (GRAS), ecofriendly, inexpensive, non-flammable, non-toxic, as well as for its high diffusion, solvent strength, and solvent-free characteristics. At room temperature, $\mathrm{CO}_{2}$ is vaporous which facilitates analytical recoveries. It can also be used at low and safe temperatures and pressures; it is recyclable, available in high purity, and does not leave residues (Herrero, et al., 2010). The critical conditions required for carbon dioxide to be at a supercritical stage occur at $31.06{ }^{\circ} \mathrm{C}$ and 7.386 MPa (Rozzi \& Singh, 2002).

SFE with $\mathrm{CO}_{2}$ has been utilized for diverse applications, including inactivating microorganisms. Inactivation with SFE is associated with pressure, temperature, and exposure time. SFE $\mathrm{CO}_{2}$ inactivates microorganisms by its penetration into the product. According to several studies, $\mathrm{CO}_{2}$ disturbs, modifies or removes the cell wall of the microorganism, lowers intracellular and extracellular $\mathrm{pH}$, and deactivates and modifies bacterial proteins and enzymes, thus causing lethal effects after its permeation into food (Hong \& Pyun, 1999; Spilimbergo, Mantoan, Quaranta, \& Mea, 2009; Werner \& Hotchkiss, 2006; Garcia-Gonzalez et al., 2009; Hotchkiss, Werner, \& Lee, 2006).

Usually, bacterial inactivation depends on pressure, temperature, exposure time, $\mathrm{pH}$, and the suspension media. The effect of supercritical $\mathrm{CO}_{2}$ has been applied to different foods to 
reduce bacterial contamination. Yuk et al. (2010) observed 7.31 log reduction, after treating $E$. coli inoculated apple cider with supercritical $\mathrm{CO}_{2}$. Choi et al. (2009) reported reductions between 0.5 to $3.5 \log$ on Escherichia coli, L. monocytogenes, Salmonella typhimurium, and E. coli O157:H7 in soy sauce and hot-pepper paste marinades, and in marinated pork products. SFE has also been used to reduce up to $7 \log$ of $E$. coli in milk broth, whole and skim milk (Erkmen, 2001), and between a 1.5 to $3 \log$ reduction of natural microflora in Spanish cheeses (SánchezMacías et. al , 2013)

While some studies examined the inactivation of foodborne pathogens in dairy products by SFE, data regarding inactivation of bacteria in soft cheeses is limited. The objectives of this study were to evaluate the efficacy of SFE in reducing the population of Listeria innocua (a surrogate for L. monocytogenes) and spoilage microorganisms (Psychrotroph, coliforms, yeast and mold) found in Mozzarella and Queso Fresco cheese. Additionally, the effect of SFE on the $\mathrm{pH}$ and water activity of Mozzarella and Queso Fresco cheese was determined.

\subsection{Materials and Methods}

\subsubsection{Bacteria Preparation}

Four strains each of L. innocua were used in this study (Table 3-1). Stock cultures were maintained frozen $\left(-70^{\circ} \mathrm{C}\right)$ for long-term preservation. Strain cultures were streaked on Tryptic Soy Agar (TSA, Neogen, Lansing, MI) and incubated at $35^{\circ} \mathrm{C}$ for $24 \mathrm{~h}$. Isolated colonies of each strain were separately grown in Tryptic Soy Broth (TSB; Neogen Corp., Lansing, MI) by placing a culture colony into $10 \mathrm{ml}$ of TSB at $35^{\circ} \mathrm{C}$ for $24 \mathrm{~h}$. Then, a four strain mixture was prepared by combining the same volume of each strain in a sterile tube. The bacterial mixture was centrifuged (3000 rpm x $15 \mathrm{~min}$ ), washed twice with $0.1 \%$ peptone water, and resuspended in $0.1 \%$ peptone water to yield up to 6-7 $\log \mathrm{CFU} / \mathrm{ml}$. The initial stock concentration was confirmed by plating on Modified Oxford Agar (MOX, Difco, Sparks, MD), containing MOX supplement (Becton, Dickinson and Company Franklin Lakes, New Jersey). 
Table 3-1: Bacteria Isolates Strain Information

\begin{tabular}{llll}
\hline Bacteria & $\begin{array}{l}\text { Strain } \\
\text { Number }\end{array}$ & Isolation Information & Source \\
\hline Listeria Innocua & B-33088 & Ovine & ARS \\
Listeria Innocua & B-33314 & Turkey/ham/cheese deli sticks & ARS \\
Listeria Innocua & B-33003 & California, USA & ARS \\
Listeria Innocua & B-33554 & Food isolate & ARS \\
\hline
\end{tabular}

ARS $=$ Agricultural Research Service (College Park, MD)

\subsubsection{Sample Preparation}

Mozzarella and Queso Fresco cheeses were purchased from a local grocery store (Food for Less; San Luis Obispo, CA) and stored at refrigeration temperatures prior to use. Each type of cheese (Queso Fresco and Mozzarella cheese) was cut into cubes $(7 \pm 5 \mathrm{~g})$ using a cheese slicer. Then, each sample was individually surface inoculated with $40 \mu \mathrm{l}$ (twice with $20 \mu \mathrm{l}$ of inoculum in each cheese's cube) of L. innocua mixture at a target concentration of $10^{5}-10^{6} \mathrm{log} \mathrm{CFU} / \mathrm{g}$. Samples were then dried in a laminar flow hood for approximately $45 \mathrm{~min}$. Inoculated and control (uninoculated) samples to be treated with SFE were placed into sterile SFE bags (Ken-Ag break proof in line tube filtration bags, Nelson Jameson, Marshfield, WI). Bags were sealed using a stapler (747 Classic Staplers, Swingline, Lincolnshire, IL). Control samples were placed in filter whirl-pack bags (NascoFort, Atkinson, WI). All Samples were then incubated at $4^{\circ} \mathrm{C}$ overnight $(12-24 \mathrm{~h})$ and then transported from the Food Safety Laboratory to Cal Poly Tech Park installations (San Luis Obispo, CA) in a cooler.

\section{$\underline{\text { 3.2.3 SFE-CO}} 2 \underline{\text { Treatment }}$}

The SFE unit used was a laboratory-scale SFE system (SFT-250, Supercritical Fluid Technologies, Newark, DE) with a maximum operating pressure of 689 bar, maximum temperature of $200^{\circ} \mathrm{C}$, and a cyclone separator capacity of $5 \mathrm{~L}$, including an automated back 
pressure regulator (Supercritical Fluid Technologies, Newark, DE). The carbon dioxide tanks used for extraction were supplied by Air Gas (50 lb., San Luis Obispo, CA). The internal surfaces of the SFE machine vessel were sterilized with a $70 \%$ ethanol solution and allowed to dry. The SFE treatments tested were 120 bar at $40^{\circ} \mathrm{C}$ and 150 bar at $50^{\circ} \mathrm{C}$ for $30 \mathrm{~min}$. The temperature had a variation of approximately plus or minus $10^{\circ} \mathrm{C}$ due to the action of adiabatic heating during pressurization and the limitation of the equipment.

\section{$\underline{\text { 3.2.4 SFE-CO }} 2 \underline{2} \underline{\text { Treatment Procedure }}$}

First, the chiller was turned on; when the chiller temperature reached $0^{\circ} \mathrm{C}$, samples were placed into the vessel (Appendix $\mathrm{C}$, Fig 1). The vessel and $\mathrm{CO}_{2}$ inlet fitting were tightly closed. Second, the SFE switch was turned on and the $\mathrm{CO}_{2}$ valve was opened. The pressure and temperature parameters were entered. Then, the $\mathrm{CO}_{2}$ and air supply valve were turned to the open position. Once the desired parameters (pressure and temperature) were stabilized, samples were held under these conditions for 30 min. A minimal $\mathrm{CO}_{2}$ flow (0-20 SCFT) was often used to maintain the right pressure. After 30 min had elapsed, the $\mathrm{CO}_{2}$ and air supply valve were turned off and the $\mathrm{CO}_{2}$ valve was closed. The quick release exhaust valve was opened to permit $\mathrm{CO}_{2}$ to exit the system (depressurization). Depressurization time took approximately 14 to $40 \mathrm{~min}$. Once the pressure reached $0^{\circ} \mathrm{C}$, the vessel and $\mathrm{CO}_{2}$ inlet fitting were disconnected and the SFE switch and chiller were turned off. Then, samples were taken out of the vessel and transferred to a cooler to transport samples back to the laboratory. Samples were transferred from SFE bags into sterile whirl pack bags in a biological safety cabinet and microbiologically analyzed.

\subsubsection{Microbial Analysis}

After samples were treated with SFE at two pressures and temperatures $\left(120\right.$ bar at $40^{\circ} \mathrm{C}$ and 150 bar at $50^{\circ} \mathrm{C}$ ) for $30 \mathrm{~min}$, treated and untreated samples were analyzed for L. innocua, coliforms, yeasts and molds, psychrotrophs, $\mathrm{pH}$, and water activity immediately after treatment and at $24 \mathrm{~h}$. On each tested day (day 0 and 1), the inoculated samples were tested for the 
pathogenic organism, and un-inoculated samples were also tested for $\mathrm{pH}$, water activity, coliforms, psychrotrophs, yeast, and mold. For all microbial enumerations, a sample of cheese was blended with a 1:10 solution of $0.1 \%$ peptone water and homogenized in a stomacher for 60 seconds. Then, an appropriate serial dilution with $0.1 \%$ peptone water for plating was achieved. For the recovery of stressed or injured cells of L. innocua and coliforms, dilutions were placed on the plates and overlaid with a thin layer of TSA and incubated $35^{\circ} \mathrm{C}$ for $2-3 \mathrm{~h}$ to permit stressed and injured cells to repair (Lavieri et al., 2014). Plates were then overlaid with selective/differential media and incubated at $35^{\circ} \mathrm{C}$ for 24 to $48 \mathrm{~h}$. Listeria innocua plated on Modified Oxford Agar (MOX, Difco, Sparks, MD) containing MOX supplement (Becton, Dickinson and Company Franklin Lakes, New Jersey) were incubated at $35^{\circ} \mathrm{C}$ for $24-48 \mathrm{~h}$, and coliforms on Violet Red Bile Agar (VRBA, Neogen, Lansing, MI) were incubated for $24 \mathrm{~h}$ at $35^{\circ}$ C. Psychrotrophs were plated on Standard Method Agar (SMA, Neogen, Lansing, MI) and incubated at $8^{\circ} \mathrm{C}$ for 10 days. Yeast and mold on Potato Dextrose Agar (PDA, Remel Products, Lenexa, KS) were incubated at $20-25^{\circ} \mathrm{C}$ for 2 to 7 days. Colonies of each organism were counted and recorded.

\subsubsection{Physio-Chemical Analysis}

For $\mathrm{pH}$ measurements, cheese was mixed with distilled water at a 1:1 ratio and measured using a pH meter (Oakton Instruments, Vernon Hills, IL). Water activity measurements (Aw) were done using a water activity meter (AquaLab 4TE; Decagon Devices Inc., Pullman, WA). SFE action on the appearance of the cheese was also evaluated by visual observation of cheese texture and color.

\subsubsection{Statistical Analysis}

The experiment was repeated twice $(n=6)$. Values are expressed as mean \pm standard deviation. All statistical analyses were conducted with JMP (version Pro 11; SAS Institute Inc., Cary, NC) software. All data, except for $\mathrm{pH}$ and water activity, were log-transformed then 
analyzed using Analysis of Variance (ANOVA). The effect of replication was blocked to avoid the variations for each replicate. Tukey's test was used to identify significant differences between treatments $(\mathrm{p}<0.05)$.

\subsection{Results}

Before SFE treatment, the initial population of L. innocua in Queso Fresco was between 5.8-6.8 log CFU/g and remained constant in untreated samples overtime. SFE reduced L. innocua population levels significantly on treated samples and without re-growth or changes posttreatment $(\mathrm{p}<0.05)$ (Table 3-2). Increasing SFE pressure and temperature decreased L. innocua in Queso Fresco by approximately $2 \log \mathrm{CFU} / \mathrm{g}$ more when SFE at 150 bar with $50^{\circ} \mathrm{C}$ was tested compared to 120 bar with $40^{\circ} \mathrm{C}$ for 30 min. However, the initial inoculum level was 1 log higher on samples treated with SFE at 150 bar with $50^{\circ} \mathrm{C}$.

For Mozzarella cheese, the L. innocua initial population was between 5.7-5.8 log CFU/g and remained constant overtime in untreated samples. SFE significantly $(\mathrm{p}<0.05)$ reduced $L$. innocua by more than $3 \log \mathrm{CFU} / \mathrm{g}$ and no significance difference between treatments was observed. Increasing SFE pressure and temperatures did not result in a higher population inactivation as seen in Queso Fresco SFE treatment (Table 3-3).

In the same way, SFE was effective in reducing psychrotroph counts in Queso Fresco cheese. The initial population of psychrotrophs was between 6.6 to $7.7 \log$ CFU/g and remained constant over time in untreated samples. Increasing SFE pressure and temperature, with SFE at 150 bar at $50^{\circ} \mathrm{C}$ resulted in a reduction of $2 \log \mathrm{CFU} / \mathrm{g}$ greater when compared to SFE at $140 \mathrm{bar}$ with $40^{\circ} \mathrm{C}$; inactivation was maintained over time. Psychrotroph counts in Queso Fresco for SFE at 150 bar with $50^{\circ} \mathrm{C}$ samples were below the detection limit on treated samples on day 1 of posttreatment (Table 3-4). In Mozzarella cheese, psychrotroph counts were below the detection limit on treated and non-treated samples at each SFE parameter tested (data not shown). 
Table 3-2: Effect of SFE on L. innocua Population $(\log$ CFU/g) in Queso Fresco Cheese

\begin{tabular}{|c|c|c|c|c|c|}
\hline \multirow[b]{2}{*}{ Storage Day } & \multirow[b]{2}{*}{$\begin{array}{l}\text { Pressure } \\
\text { (bar) }\end{array}$} & \multirow[b]{2}{*}{$\begin{array}{l}\text { Temperature } \\
\left({ }^{\circ} \mathrm{C}\right)\end{array}$} & \multicolumn{3}{|c|}{ L. innocua $\log \mathrm{CFU} / \mathrm{g}$} \\
\hline & & & Non-SFE & SFE & Reduction \\
\hline \multirow[t]{2}{*}{ Day 0} & 120 & 40 & $5.86 \pm 0.10^{\mathrm{Aa}}$ & $2.85 \pm 0.0 .67^{\mathrm{Ba}}$ & 3.01 \\
\hline & 150 & 50 & $6.89 \pm 0.34^{\mathrm{Ab}}$ & $1.76 \pm 0.49^{\mathrm{Bb}}$ & 5.13 \\
\hline \multirow[t]{2}{*}{ Day 1} & 120 & 40 & $5.74 \pm 0.10^{\mathrm{Aa}}$ & $2.61 \pm 0.64^{\mathrm{Ba}}$ & 3.13 \\
\hline & 150 & 50 & $7.13 \pm 0.35^{\mathrm{Ab}}$ & $1.51 \pm 0.35^{\mathrm{Bb}}$ & 5.62 \\
\hline
\end{tabular}

${ }^{A}{ }^{\text {to }}$ Means with different capital letters in the same row are significantly different $(p<0.05)$.

$a$ to $b$ Means with different lower case letters in the same column are significantly different $(\mathrm{p}<0.05)$. Reduction values were obtained by subtracting the $\log \mathrm{CFU} / \mathrm{g}$ of the non-SFE treated samples minus log CFU/g SFE per storage day, pressure, and temperature

Table 3-3: Effect of SFE on the Growth L. innocua $(\log$ CFU/g) in Mozzarella Cheese

\begin{tabular}{|c|c|c|c|c|c|}
\hline \multirow[b]{2}{*}{ Storage Day } & \multirow[b]{2}{*}{$\begin{array}{l}\text { Pressure } \\
\text { (bar) }\end{array}$} & \multirow[b]{2}{*}{$\begin{array}{l}\text { Temperature } \\
\left({ }^{\circ} \mathrm{C}\right)\end{array}$} & \multicolumn{3}{|c|}{ L. innocua $\log \mathrm{CFU} / \mathrm{g}$} \\
\hline & & & Non-SFE & SFE & Reduction \\
\hline \multirow[t]{2}{*}{ Day 0} & 120 & 40 & $\underset{\mathrm{Aa}}{5.84} \pm 0.14$ & $2.14 \pm 0.47^{\mathrm{Ba}}$ & 3.70 \\
\hline & 150 & 50 & $\underset{\text { Aa }}{5.71} \pm 0.11$ & $1.93 \pm 0.38^{\mathrm{Ba}}$ & 3.78 \\
\hline \multirow[t]{3}{*}{ Day 1} & \multirow[t]{2}{*}{120} & \multirow{2}{*}{40} & \multirow{2}{*}{$\underset{\mathrm{Aa}}{5.59} \pm 0.26$} & $2.81 \pm 1.40^{\mathrm{Ba}}$ & 2.78 \\
\hline & & & & $2.28 \pm 0.60^{* \mathrm{Ba}}$ & 3.31 \\
\hline & 150 & 50 & $5.64 \pm 0.07^{\mathrm{Aa}}$ & $1.94 \pm 0.17^{\mathrm{Ba}}$ & 3.70 \\
\hline
\end{tabular}

${ }^{A}$ to $B$ Means with different capital letters in the same row are significantly different $(p<0.05)$.

$a$ to $b$ Means with different lower case letters in the same column are significantly different $(\mathrm{p}<0.05)$. Reduction values were obtained by subtracting the $\log \mathrm{CFU} / \mathrm{g}$ of the non-SFE treated samples minus log CFU/g SFE per storage day, pressure, and temperature

* Mean \pm standard deviation followed the removal of an outlier 
Table 3-4: Effect of SFE on Psychrotroph Population (log CFU/g) in Queso Fresco Cheese

\begin{tabular}{|c|c|c|c|c|c|}
\hline \multirow[b]{2}{*}{ Storage Day } & \multirow[b]{2}{*}{$\begin{array}{l}\text { Pressure } \\
\text { (bar) }\end{array}$} & \multirow[b]{2}{*}{$\begin{array}{l}\text { Temperature } \\
\left({ }^{\circ} \mathrm{C}\right)\end{array}$} & \multirow{2}{*}{$\begin{array}{l}\text { Psychrotroph } \\
\text { Non-SFE }\end{array}$} & \multicolumn{2}{|l|}{$\log \mathrm{CFU} / \mathrm{g}$} \\
\hline & & & & SFE & Reduction \\
\hline \multirow{2}{*}{ Day 0} & 120 & 40 & $6.64 \pm 0.18^{\mathrm{Aa}}$ & $3.33 \pm 1.22^{\mathrm{Ba}}$ & 3.31 \\
\hline & 150 & 50 & $7.34 \pm 0.39^{\mathrm{Aa}}$ & $1.86 \pm 0.99^{\mathrm{Bb}}$ & 5.58 \\
\hline \multirow{2}{*}{ Day 1} & 120 & 40 & $7.01 \pm 0.06^{\mathrm{Aa}}$ & $3.77 \pm 1.45^{\mathrm{Ba}}$ & 3.24 \\
\hline & 150 & 50 & $7.67 \pm 0.30^{\mathrm{Aa}}$ & $<1^{\mathrm{Bb}}$ & $6.77^{1}$ \\
\hline
\end{tabular}

The population of Coliforms was no significantly difference between SFE at 150 bar with $50^{\circ} \mathrm{C}$ compared to 140 bar with $40^{\circ} \mathrm{C}$ for $30 \mathrm{~min}$ over time, with a total reduction of approximately $4 \log$ CFU/g (Table 3-5). However, coliforms initial population in Queso Fresco was approximately $2 \operatorname{logs}$ higher on samples treated with SFE at 150 bar with $50^{\circ} \mathrm{C}$ for $30 \mathrm{~min}$. Mozzarella cheese coliforms were below the detection limit on treated and non-treated samples at each of the SFE parameters tested (data not shown).

Yeast initial population in Queso Fresco for non-treated samples was approximately $2 \log$ CFU/g, and remained constant after day 1 of post-treatment. Regardless of SFE treatments tested, yeast counts were and remained below the detection limit after day 1 of post-treatment. SFE treatments were not significantly different; the yeast population was reduced to $\geq 1 \log \mathrm{CFU} / \mathrm{g}$ after all SFE treatments (Table 3-6), while the mold population was below detection limit. At the same time, in Mozzarella cheese, yeast and mold populations were below the detection limit on treated and non-treated samples at each SFE parameter tested (data not shown). 
Table 3-5: Effect of SFE on Coliforms Population (log CFU/g) in Queso Fresco Cheese

\begin{tabular}{|c|c|c|c|c|c|}
\hline \multirow[b]{2}{*}{ Storage Day } & \multirow[b]{2}{*}{$\begin{array}{l}\text { Pressure } \\
\text { (bar) }\end{array}$} & \multirow[b]{2}{*}{$\begin{array}{l}\text { Temperature } \\
\left({ }^{\circ} \mathrm{C}\right)\end{array}$} & \multirow{2}{*}{$\begin{array}{l}\text { Coliforms } \\
\text { Non-SFE }\end{array}$} & \multicolumn{2}{|l|}{$(\log$ CFU/g) } \\
\hline & & & & SFE & Reduction \\
\hline \multirow[t]{2}{*}{ Day 0} & 120 & 40 & $4.53 \pm 1.66^{\mathrm{Aa}}$ & $0.79 \pm 0.60^{\mathrm{Ba}}$ & 3.74 \\
\hline & 150 & 50 & $7.37 \pm 0.58^{\mathrm{Ab}}$ & $1.69 \pm 1.27^{\mathrm{Ba}}$ & 5.68 \\
\hline \multirow[t]{2}{*}{ Day 1} & 120 & 40 & $5.35 \pm 1.57^{\mathrm{Aa}}$ & $1.19 \pm 0.53^{\mathrm{Ba}}$ & 4.16 \\
\hline & 150 & 50 & $7.67 \pm 0.28^{\mathrm{Ab}}$ & $2.59 \pm 2.45^{\mathrm{Ba}}$ & 5.08 \\
\hline
\end{tabular}

${ }^{\mathrm{A} \text { to } \mathrm{B}}$ Means with different capital letters in the same row are significantly different $(\mathrm{p}<0.05)$.

$a$ to $b$ Means with different lower case letters in the same column are significantly different $(p<0.05)$. Reduction values were obtained by subtracting the $\log C F U / g$ of the non-SFE treated samples minus log CFU/g SFE per storage day, pressure, and temperature

Table 3-6: Effect of SFE on the Growth of Yeast Population (log CFU/g) in Queso Fresco Cheese

\begin{tabular}{|c|c|c|c|c|c|}
\hline \multirow[b]{2}{*}{ Storage Day } & \multirow[b]{2}{*}{$\begin{array}{l}\text { Pressure } \\
\text { (bar) }\end{array}$} & \multirow[b]{2}{*}{$\begin{array}{l}\text { Temperature } \\
\left({ }^{\circ} \mathrm{C}\right)\end{array}$} & \multirow{2}{*}{$\frac{\text { Yeast }}{\text { Non-SFE }}$} & \multicolumn{2}{|l|}{$(\log \mathrm{CFU} / \mathrm{g})$} \\
\hline & & & & SFE & Reduction $^{1}$ \\
\hline \multirow[t]{2}{*}{ Day 0} & 120 & 40 & $2.27 \pm 0.63^{\mathrm{Aa}}$ & $<1^{\mathrm{Ba}}$ & 1.39 \\
\hline & 150 & 50 & $2.38 \pm 0.46^{\mathrm{Aa}}$ & $<1^{\mathrm{Ba}}$ & 1.48 \\
\hline \multirow[t]{2}{*}{ Day 1} & 120 & 40 & $2.50 \pm 0.42^{\mathrm{Aa}}$ & $<1^{\mathrm{Ba}}$ & 1.62 \\
\hline & 150 & 50 & $2.13 \pm 0.43^{\mathrm{Aa}}$ & $<1^{\mathrm{Ba}}$ & 1.23 \\
\hline
\end{tabular}

${ }^{A}$ to $B$ Means with different capital letters in the same row are significantly different $(\mathrm{p}<0.05)$.

$a$ to $b$ Means with different lower case letters in the same column are significantly different $(\mathrm{p}<0.05)$. Reduction values were obtained by subtracting the $\log \mathrm{CFU} / \mathrm{g}$ of the non-SFE treated samples minus log CFU/g SFE per storage day, pressure, and temperature

${ }^{1}$ When colonies were $<1 \log (\mathrm{CFU} / \mathrm{g})$, reductions were determined by subtracting $0.9 \log \mathrm{CFU} / \mathrm{g}$ minus non-SFE samples

The $\mathrm{pH}$ of Queso Fresco was significantly lower by 0.10 between SFE and non-SFE samples (Table 3-7). Although the $\mathrm{pH}$ of Queso Fresco treated with SFE was significantly lower than non-SFE samples, the $\mathrm{pH}$ was still within the normal $\mathrm{pH}$ range (6.0-6.7 $\mathrm{pH})$ for Queso 
Fresco standards (Hongmei, Zhong, Liao, \& Hu, 2014). In Mozzarella cheese, the pH of SFE was not significantly different from non-SFE samples. However, treated samples at 120 bar with $40^{\circ} \mathrm{C}$ were different to SFE samples at 150 bar with $50^{\circ} \mathrm{C}$. The $\mathrm{pH}$ of Mozzarella cheese also significantly increased in the non-SFE samples at 150 bar, after day 1 of post-treatment. Although there was an increase in Mozzarella cheese $\mathrm{pH}$, it was still not significant in terms of quality and was within the range (5.0-5.4 $\mathrm{pH}$ ) established by the USDA (USDA, 2012). The average $\mathrm{pH}$ for samples tested at 120 bar was 5.19 and the average $\mathrm{pH}$ for SFE samples at 150 bar was 5.38 . Therefore, SFE treatment is not likely to impact the quality $\mathrm{pH}$ in Mozzarella cheese (Table 3-8).

Table 3-7: Effect of SFE on pH of Queso Fresco Cheese

\begin{tabular}{lllll} 
Storage Day & Pressure (bar) & Temperature $\left({ }^{\circ} \mathrm{C}\right)$ & Non-SFE & SFE \\
\hline Day 0 & 120 & 40 & $6.57 \pm 0.04^{\mathrm{Aa}}$ & $6.46 \pm 0.12^{\mathrm{Ba}}$ \\
& 150 & 50 & $6.62 \pm 0.05^{\mathrm{Aa}}$ & $6.50 \pm 0.09^{\mathrm{Ba}}$ \\
& 120 & 40 & $6.74 \pm 0.01^{\mathrm{Ab}}$ & $6.59 \pm 0.02^{\mathrm{Bb}}$ \\
Day 1 & 150 & 50 & $6.64 \pm 0.05^{\mathrm{Aa}}$ & $6.49 \pm 0.06^{\mathrm{Ba}}$ \\
& & & &
\end{tabular}

Values are presented as the mean \pm standard deviation $(n=6)$.

${ }^{A}$ to $\mathrm{B}$ Means with different capital letters in the same row are significantly different $(p<0.05)$.

a to $b$ Means with different lower case letters in the same column are significantly different $(\mathrm{p}<0.05)$

The water activities of Queso Fresco SFE samples were not significantly different from the control group (Table 3-9). The average water activity was between 0.9718 to 0.9751 in treated and non-treated samples. In Mozzarella cheese treated with SFE, water activity was not significantly different between SFE and non-SFE samples (Table 3-10). The initial water activity was similar between non-treated samples, but it was different between SFE at 120 with $40^{\circ} \mathrm{C}$ on day 1 of post-treatment. 
Table 3-8: Effect of SFE on pH on Mozzarella Cheese

\begin{tabular}{lllll}
\hline Storage Day & Pressure (bar) & Temperature $\left({ }^{\circ} \mathrm{C}\right)$ & Non-SFE & SFE \\
\hline Day 0 & 120 & 40 & $5.22 \pm 0.06^{\mathrm{Aa}}$ & $5.22 \pm 0.05^{\mathrm{Aa}}$ \\
& 150 & 50 & $5.33 \pm 0.04^{\mathrm{Ab}}$ & $5.34 \pm 0.02^{\mathrm{Ab}}$ \\
Day 1 & 120 & 40 & $5.17 \pm 0.02^{\mathrm{Aa}}$ & $5.18 \pm 0.02^{\mathrm{Aa}}$ \\
& 150 & 50 & $5.44 \pm 0.10^{\mathrm{Ac}}$ & $5.43 \pm 0.08^{\mathrm{Ab}}$ \\
\hline
\end{tabular}

Values are presented as the mean \pm standard deviation $(n=6)$.

${ }^{A}$ to $B$ Means with different capital letters in the same row are significantly different $(p<0.05)$.

$a$ to $b$ Means with different lower case letters in the same column are significantly different $(\mathrm{p}<0.05)$

Table 3-9: Effect of SFE on Water Activity (Aw) in Queso Fresco Cheese

\begin{tabular}{|c|c|c|c|c|}
\hline $\begin{array}{l}\text { Storage } \\
\text { Day }\end{array}$ & $\begin{array}{l}\text { Pressure } \\
\text { (bar) }\end{array}$ & $\begin{array}{l}\text { Temperature } \\
\left({ }^{\circ} \mathrm{C}\right)\end{array}$ & Non-SFE & SFE \\
\hline \multirow[t]{2}{*}{ Day 0} & 120 & 40 & $0.9737 \pm 0.0040^{\text {Aab }}$ & $0.9718 \pm 0.0023^{\text {Aabc }}$ \\
\hline & 150 & 50 & $0.9766 \pm 0.0032^{\mathrm{Aa}}$ & $0.9760 \pm 0.0045^{\mathrm{Aa}}$ \\
\hline \multirow[t]{2}{*}{ Day 1} & 120 & 40 & $0.9676 \pm 0.0036^{\mathrm{Ab}}$ & $0.9655 \pm 0.0054^{\mathrm{Ac}}$ \\
\hline & 150 & 50 & $0.9760 \pm 0.0034^{\mathrm{Aa}}$ & $0.9737 \pm 0.0058^{\mathrm{Aab}}$ \\
\hline
\end{tabular}


Table 3-10: Effect of SFE on Water Activity (Aw) in Mozzarella Cheese

\begin{tabular}{lllll}
\hline Storage Day & Pressure (bar) & $\begin{array}{l}\text { Temperature } \\
\left({ }^{\circ} \mathrm{C}\right)\end{array}$ & Non-SFE & SFE \\
\hline Day 0 & 120 & 40 & $0.9572+0.0045^{\mathrm{Abc}}$ & $0.9532 \pm 0.0014^{\mathrm{Aa}}$ \\
& 150 & 50 & $0.9642 \pm 0.0037^{\mathrm{Aab}}$ & $0.9639 \pm 0.0034^{\mathrm{Ab}}$ \\
& & & & \\
Day 1 & 120 & 40 & $0.9553 \pm 0.0033^{\mathrm{Bb}}$ & $0.9562 \pm 0.0029^{\mathrm{Bb}}$ \\
& 150 & 50 & $0.9656 \pm 0.0027^{\mathrm{Aa}}$ & $0.9546 \pm 0.0015^{\mathrm{Ab}}$ \\
& & & & \\
\hline
\end{tabular}

\footnotetext{
${ }^{\text {A to B }}$ Means with different capital letters in the same row are significantly different $(p<0.05)$.

$a$ to $b$ Means with different lower case letters in the same column are significantly different $(\mathrm{p}<0.05)$
}

The physical appearance of Queso Fresco remained with the same texture and appearance regardless of which parameter was tested (Fig 3-1to 3-5), while Mozzarella cheese showed some 'drier' aspects with a hard texture, and some signs of lighter discoloration, which intensified at a higher pressure and temperature $\left(150\right.$ bar and $\left.50^{\circ} \mathrm{C}\right)$. Mozzarella cheese treated under extreme SFE conditions also showed signs of deformation, such some openings and splits in the surface.

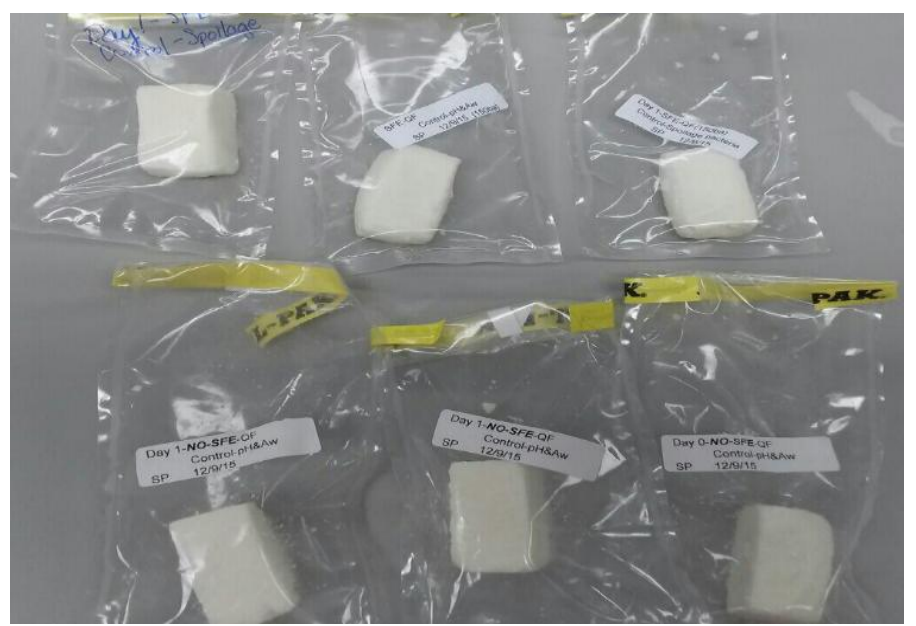

Figure 3-1: Appearance of Queso Fresco after (top) and before SFE (bottom) Treatment at 150 Bar with $50^{\circ} \mathrm{C}$ for $30 \mathrm{~min}$ 


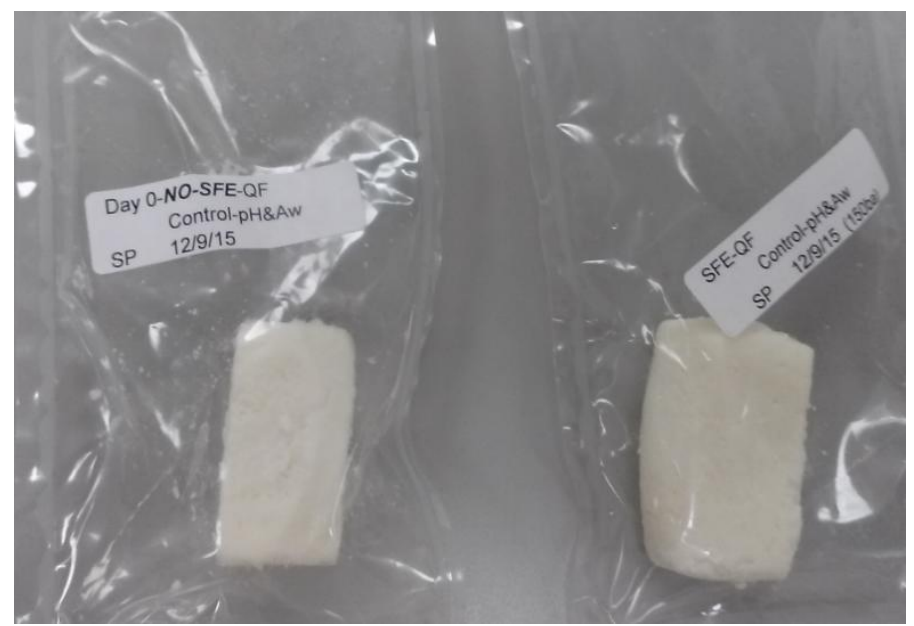

Figure 3-2: Appearance of Queso Fresco before (left) and after SFE (right) Treatment at 120 Bar with $40^{\circ} \mathrm{C}$ for $30 \mathrm{~min}$

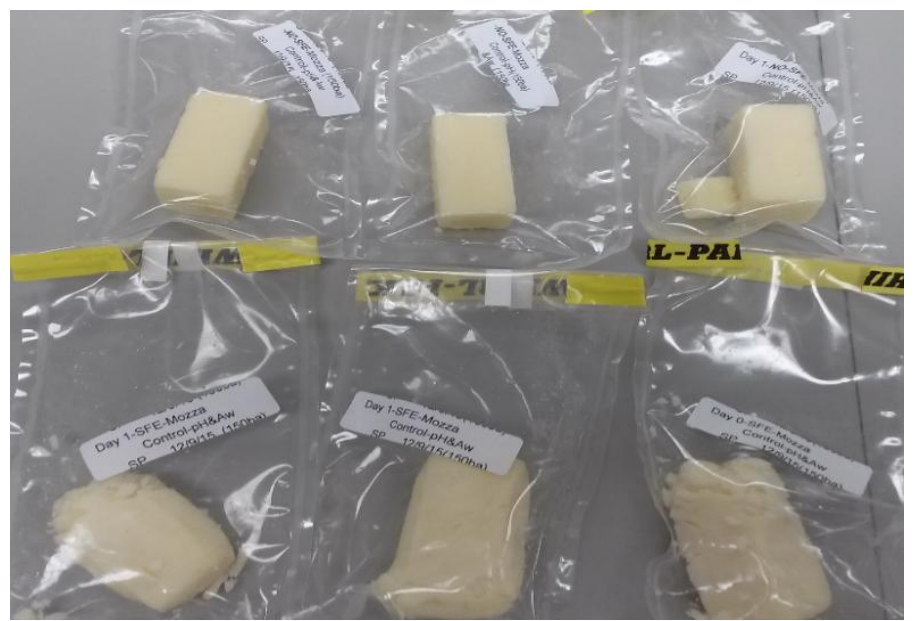

Figure 3-3: Appearance of Mozzarella Cheese before (top) and after SFE (bottom) Treatment at 150 Bar with $50^{\circ} \mathrm{C}$ for $30 \mathrm{~min}$ 


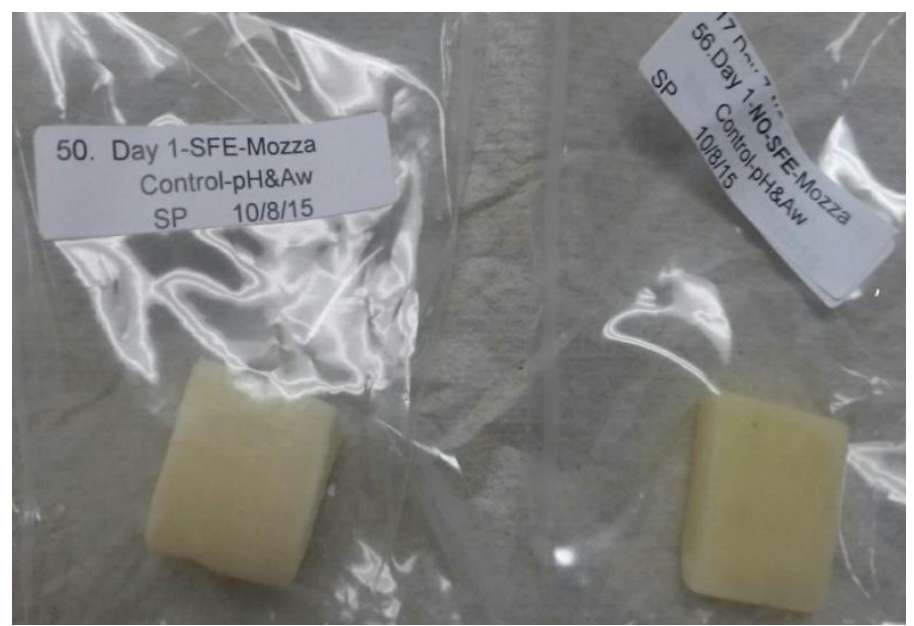

Figure 3-4: Appearance of Mozzarella Cheese after (left) and before SFE (right) Treatment at 120 Bar with $40^{\circ} \mathrm{C}$ for $30 \mathrm{~min}$

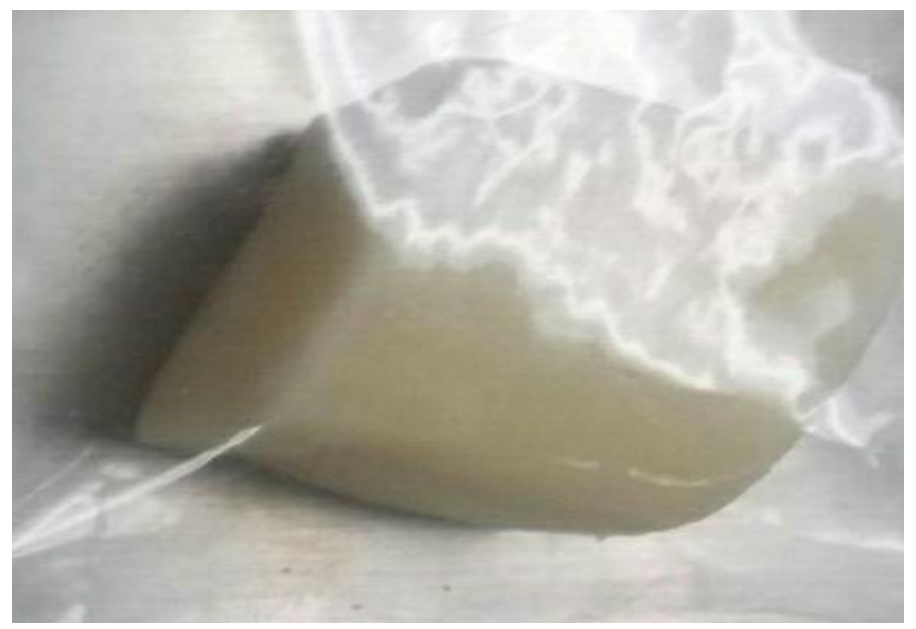

Figure 3-5: Appearance of Mozzarella Cheese after SFE treatment at 120 bar with $40^{\circ} \mathrm{C}$ for 30 $\min$

\subsection{Discussion}

Listeria innocua was significantly $(\mathrm{p}<0.05)$ reduced in Queso Fresco and Mozzarella cheese after SFE treatment. Studies have demonstrated that SFE reductions are determined by pressure, temperature, water content, $\mathrm{pH}$, and components of food matrix, food type, microorganisms, and/or a combination of all these factors (Hong \& Pyun, 1999). In this experiment, it appears that the SFE inactivation effect was related to pressure, temperature, and the food matrix. Although greater temperature and pressure during SFE treatment led to higher inactivation in the L. innocua and psychrotroph counts in Queso Fresco, SFE treatment under 
higher temperatures and pressures did not always increase L. innocua reduction in Mozzarella cheese. Mozzarella cheese inactivation rate was approximately $2 \log$ CFU/g lower than that seen in Queso Fresco regardless of SFE treatment. Reduction of bacteria by SFE has yield mixed results; whereby an increment of pressure and temperature is not always significantly different than control. For instance, increasing SFE pressure from 100 to 120 bar and simultaneously increasing temperature from 40 to $45^{\circ} \mathrm{C}$ did not significantly inactivate mesophilic bacteria, but it did when SFE at 140 bar with $45^{\circ} \mathrm{C}$ was tested. However, L. monocytogenes and S. Typhimurium population reductions were always higher when the temperature increased regardless of pressure on SFE treatments when tested on ground pork (Young Bae, Hee Kim, Heon Kim, Chul Kim, \& Suk Rhee, 2011).

In the present study, Mozzarella cheese and Queso Fresco had different $\mathrm{pH}$ and water activity content which could have impacted the difference of reductions. SFE treatments at higher temperatures and pressures with increased reduction only in Queso Fresco could be due to food type, or the chemical characteristics of food type and structure. Microbial inactivation by SFE might also depend on the medium and its water activity. Mozzarella cheese had a slightly lower water activity than Queso Fresco, which may have caused a lower inactivation rate than that observed for Queso Fresco. Products with a higher water activity have a better $\mathrm{CO}_{2}$ solubility, thus enabling the inhibitory action of $\mathrm{CO}_{2}$ on bacteria cells which results in a decrease of the $\mathrm{pH}$ of the medium (Jung, Choi, \& Rhee, 2009; Garcia-Gonzalez et al., 2007). Similarly, SFE treatment at 100,120 , or 140 bar with temperatures at 40 or 45 for 20,30 , or 40 min was more effective at inactivating pathogenic bacteria (E. coli, L. monocytogenes, S. typhimurium, and $E$. coli $\mathrm{O} 157: \mathrm{H7}$ ) in marinated pastes (soy and hot-pepper) than marinated pork due to higher water content in marinates than pork products (Choi et al., 2009).

In the present study, the lethality effect of SFE on Queso Fresco was higher than that seen for Mozzarella cheese. During SFE treatment, Queso Fresco seemed more porous and softer 
than Mozzarella cheese. Due to those observed characteristics, the higher lethality in Queso Fresco could be attributed to the cheese's microstructure. Sánchez-Macías et al., (2013) found that Majorero cheese's natural microflora inactivation was approximately $2 \log$ CFU/g lower than a Gouda type cheese regardless of an increment on pressure. However, for microbial counts in Gouda cheese, SFE decreased by increasing pressure. Differences in microbial inactivation on those Spanish cheeses was caused by the cheese microstructure, with Gouda type cheese texture providing an improved $\mathrm{CO}_{2}$ diffusion compared to Majorero cheese. A similar situation could have occurred in the present study causing a lower reduction in Mozzarella than in Queso Fresco cheese. $\mathrm{CO}_{2}$ could less effectively diffused into Mozzarella due to the minimal presence of a whey matrix which might have restrained the action of SFE (Oberg, MC Manus, \& MC Mahon, 1993).

Another possible explanation for the smaller reduction in Mozzarella cheese might be the result of a lower initial inoculum level of L. innocua in Mozzarella than in Queso Fresco by approximately $1 \log \mathrm{CFU} / \mathrm{g}$ causing a 'tailing effect' which occurs during hydrostatic pressure treatments, and cell inoculations less than $7 \mathrm{log} \mathrm{CFU} / \mathrm{g}$ causing an ineffective inactivation. A tailing effect is assumed to be a consequence of the synthesis of heat shock protein due to the cell's response after pressure treatment. Components of the food matrix such as calcium ions and surfactants might enhance cellular pressure protection during the initial stage of pressurization (Noma, Kajiyama, Igura, Shimoda, \& Hayakawa, 2006). Likewise, Panagou et al. (2007) performed an evaluation of the reduction of Pediococcus damnosus (8 log CFU/g) in phosphate buffer ( $\mathrm{pH}$ 6.7) and a gilt-head seabream solution, a pressure-resistant strain, by high hydrostatic pressure treatment, which took up to $8 \mathrm{~min}$ at pressure intervals of 5000, 5500, 6000, and 6500 bar at room temperature $\left(23^{\circ} \mathrm{C}\right)$ (Panagou, Tassou, Manitsa, \& Mallidis, 2007). The tailing effect was detected on pressure resistant Pediococcus damnosus at higher pressures tested (6000 and 6500 bar) in both phosphate buffer and gilt-head seabream solutions. Although these investigators 
used higher pressures without supercritical $\mathrm{CO}_{2}$ and tailing effect is unlikely to occur under SFE treatment, their hypothesis might explain the reason for small reductions in Mozzarella cheese compared to Queso Fresco cheese when SFE at 150 bar at $50^{\circ} \mathrm{C}$ for 30 min was tested.

In the same way, SFE was effective in reducing psychrotroph, coliforms, and yeast counts in Queso Fresco cheese. Psychrotrophs were also significantly lower when SFE at 150 bar with $50^{\circ} \mathrm{C}$ was used compared to SFE at 140 bar with $40^{\circ} \mathrm{C}$. Although the results of this study were processed in a batch system apparatus, this results are similar to those reported by Werner and Hotchkiss (2006) who treated milk with SFE in a continuous flow system apparatus. Raw milk with a high concentration of psychotropic bacteria and inoculated with $P$. fluorescence showed a significant reduction of bacteria under all tested conditions compared with the control, in which the highest reduction-5.35 and $5.02 \log \mathrm{CFU} / \mathrm{mL}$ - occurred at a $\mathrm{CO}_{2}$ concentration of $132 \mathrm{~g} / \mathrm{kg}$ and $207 \mathrm{bar}$. A higher concentration of $\mathrm{CO}_{2}$ with high temperature and pressure caused a significant bacterial reduction due to increased diffusion of $\mathrm{CO}_{2}$ into bacterial cells (Werner \& Hotchkiss, 2006). Coliforms present in raw milk were also reduced, as coliforms were completely inactivated by SFE treatment with 250 bar at $40^{\circ} \mathrm{C}$ for $50 \mathrm{~min}$ by $2.17 \log \mathrm{CFU} / \mathrm{mL}$ (Hongmei et al., 2014). In this study, coliform counts in Queso Fresco cheese were reduced regardless of SFE treatment, and yeast counts were also reduced. However, these results cannot be compared due to low inoculum on Queso Fresco cheese and the results obtained could not conclusively determine the inactivation by SFE at each parameter tested. Mold counts were below the detection limit in non-treated and treated samples for Queso Fresco and Mozzarella cheese.

In the context of physical appearance, Queso Fresco maintained the same texture and appearance regardless of which parameter was tested. Similarly, Ferrentino, Balzan, and Spilimbergo (2013) also found that SFE had a little effect on the color of dry cured ham treated at a range from 35 to $50^{\circ} \mathrm{C}$ at 80 and 120 bar for 5 to $60 \mathrm{~min}$. However, in this study, the texture and color of Mozzarella cheese deteriorated at SFE treatments with higher temperature and pressure 
conditions $\left(150\right.$ bar and $\left.50^{\circ} \mathrm{C}\right)$. Mozzarella cheese treated under higher SFE parameters also showed signs of deformation, such some openings and splits in the surface. At the same time, fresh-cut coconut showed a small discoloration after SFE treatment at $12 \mathrm{MPa}, 40^{\circ} \mathrm{C}$ for $30 \mathrm{~min}$ and $12 \mathrm{MPa}, 45^{\circ} \mathrm{C}$ for $15 \mathrm{~min}$ (Ferrentino, Belscak-Cvitanovic, Komes, \& Spilimbergo, 2013). Additionally, raw pork meat treated with SFE at 25, 35, and $40{ }^{\circ} \mathrm{C}$, from 6 to $16 \mathrm{MPa}$ and from 5 to $60 \mathrm{~min}$ produced a 'whitish color and cooked appearance' after SFE treatment.

Although the previous aforementioned studies involved samples of SFE treatment in very different food matrixes to cheese, the same effect might be the cause of the microbial reduction seen in this study. Hence, it is necessary to conduct more SFE treatments using other pressures and temperatures to better understand the impact of SFE on cheese products. It is also important to mention that post-processing contamination by L. innocua in Queso Fresco and Mozzarella Cheese used in this study far exceeded potential contaminations in the Cheese industry.

\subsection{Conclusion}

SFE efficiently reduced the microbial population in Queso Fresco and Mozzarella cheese. In Queso Fresco, SFE inactivation significantly intensified at a higher pressure and temperature without visibly changing its appearance, but not in Mozzarella. Higher pressures and temperatures did not have an impact on bacterial inactivation in Mozzarella cheese without compromising the texture and color. This data suggests that SFE could potentially be used to reduce pathogenic bacteria in cheeses without negatively impacting product quality. SFE lethality is still undetermined; its bactericidal effect might be due to $\mathrm{pH}$, food matrix, and bacteria susceptibility. Particularly, in Queso Fresco cheese, SFE might also be affected by a combination of temperature, pressure, porosity, and $\mathrm{pH}$. Further research is needed to understand this system to determine any effect of SFE on other cheese products, as well its effect on a product's quality and physio-chemical characteristics over time. 


\section{CHAPTER 4: FUTURE RESEARCH}

Future research should study the behavior of pathogenic bacteria in Mozzarella cheese at very low percent of sodium (no more than $1.5 \%$ ), compared to a standard sodium concentration. This potentially challenging study should also analyze the growth of lactic acid bacteria, moisture, salt content, protein, and fat over time to have a better understanding of the food matrix and its influence on pathogenic bacteria. It will also be applicable to study other types of soft cheeses, such as Queso Fresco.

This research evaluated SFE as a potential antimicrobial in cheese. Future studies should also include the effect of SFE at different temperatures, pressures, and times and analyze other types of food products, as well as their sensory properties. Future research should also include chemical analysis, such as fat, protein, moisture content, to allow a better understanding of SFE's

effect on food components and how this affects the survival of bacteria within food treated using SFE. 


\section{REFERENCES}

Adams, M. , Moss, M. 2008. Food Microbiology. Cambridge, UK: RSC PublishingAdams, R. 2014. The salt of the matter trends in sodium. Food Product Design, (December), 5-11.

Alemdar, S., and S. Ağaoğlu. 2010. Survival of Salmonella Typhimurium during the ripening of Herby cheese (Otlu Peynir). Journal of Food Safety, 30: 526-536.

Allerberger, F. 2003. Listeria: Growth, phenotypic differentiation and molecular microbiology. FEMS Immunology and Medical Microbiology, 35(3): 183-189.

Agarwal, S., D. McCoy, W. Graves, P. D. Gerard and S. Clark. 2011. Sodium content in retail Cheddar, Mozzarella, and process cheeses varies considerably in the United States. Journal of Dairy Science, 94(3): 1605-15.

Arboatti, A. S., M. L. Olivares, N. G. Sabbag, S. C. Costa, S.E. Zorrilla and G. A. Sihufe. 2014. The influence of sodium chloride reduction on physicochemical, biochemical, rheological and sensory characteristics of Mozzarella cheese. Dairy Science \& Technology, 94 (4): 373386.

Bae, Y. Y., Y. M. Choi, M. J. Kim. K. H. Kim, B. C. Kim and M. S. Rhee. (2011). Application of supercritical carbon dioxide for microorganism reductions in fresh pork. Journal of Food Safety, 31(4), 511-517.

Banjara, N., M. J. Suhr and H. E Hallen-Adams. 2015. Diversity of Yeast and Mold Species from a Variety of Cheese Types. Current Microbiology, 70(6): 792-800.

Bentley, J. 2014. Trends in U.S. per capita consumption of dairy products, 1970-2012. Amber Waves, $1 \mathrm{~F}$.

Cagri-Mehmetoglu, A., G.Yaldirak, T. Bodur, M. Simsek, H. Bozkir and N. M. Eren. 2011. Incidence of Listeria monocytogenes and Escherichia coli O157:H7 in two Kasar Cheese processing environments. Food Control, 22(5): 762-766.

Can, F. O., A. Demirci, V.M. Puri and H. Gourama. 2014. Decontamination of Hard Cheeses by Pulsed UV Light. Journal of Food Protection, 77(10): 1723-1731.

Cappelletti, M., G. Ferrentino and S. Spilimbergo. 2015. High pressure carbon dioxide on pork raw meat: Inactivation of mesophilic bacteria and effects on colour properties. Journal of Food Engineering, 156(2015): 55-58.

Centers for Disease Control and Prevention (CDC). 2011. Surveillance for Foodborne Disease Outbreaks United States,2008: Annual Report. US Deparment of Health and Human Services. Available at http://www.cdc.gov/mmwr/preview/mmwrhtml $/ \mathrm{mm} 6035 \mathrm{a} 3 . \mathrm{htm}$ Accessed 11 July 2015.

Centers for Disease Control and Prevention (CDC). 2013. Surveillance for Foodborne Disease Outbreaks United States,2009-2010: Annual Report. US Deparment of Health and Human 
Services. Available at http://www.cdc.gov/mmwr/pdf/wk/mm6203.pdf. Accessed 16 July 2015 .

Centers for Disease Control and Prevention (CDC). 2014a. Surveillance for Foodborne Disease Outbreaks United States, 2012: Annual Report. US Deparment of Health and Human Services. Available at http://www.cdc.gov/foodsafety/pdfs/foodborne-disease-outbreaksannual-report-2012-508c.pdf. Accessed 16 July 2015.

Centers for Disease Control and Prevention (CDC). 2014b. Surveillance for Foodborne Disease Outbreaks United States, 2011: Annual Report. US Deparment of Health and Human Services. Available at http://www.cdc.gov/foodsafety/pdfs/foodborne-disease-outbreaksannual-report-2011-508c.pdf. Accessed 16 July 2015.

Centers for Disease Control and Prevention (CDC). 2014c. Multistate outbreak of listeriosis linked to Roos Food Dairy Products. US Deparment of Health and Human Services. Available at http://www.cdc.gov/listeria/outbreaks/cheese-02-14/.pdf. Accessed 16 July 2015.

Centers for Disease Control and Prevention (CDC). 2015. Surveillance for Foodborne Disease Outbreaks United States, 2013: Annual Report. US Deparment of Health and Human Services. Available at http://www.cdc.gov/foodsafety/pdfs/foodborne-disease-outbreaksannual-report-2013-508c.pdf. Accessed 16 July 2015.

Center for Science in the Public Interest. 2012. Outbreak Alert! Database.

Chandan, R. C., H. Marin, K. R. Nakrani and M.D. Zehner. 1979. Production and Consumer Acceptance of Latin American White Cheese. Journal of Dairy Science, 62(5): 691-696.

Choi, Y. M., Y. Y. Bae, K.H. Kim, B.C.Kim and M.S. Rhee. 2009. Effects of supercritical carbon dioxide treatment against generic Escherichia coli, Listeria monocytogenes, Salmonella typhimurium, and E. coli O157:H7 in marinades and marinated pork. Meat Science, 82 (4): 419-424.

Cruz, A. G., J. A. F. Faria, M. A. Pollonio, H. M. A Bolini, R. M. S. Celeghini, D. Granato and N. P. Shah. 2011. Cheeses with reduced sodium content: Effects on functionality, public health benefits and sensory properties. Trends in Food Science \& Technology, 22(6): 276291.

D’Amico, D. J., M. J. Druart and C.W. Donnelly. 2010. Behavior of Escherichia coli O157:H7 during the manufacture and aging of Gouda and stirred-curd Cheddar cheeses manufactured from raw milk. Journal of Food Protection, 73(12): 2217-2224.

Erkmen, O. 2001. Effects of high-pressure carbon dioxide on Escherichia coli in nutrient broth and milk. International Journal of Food Microbiology, 65 (1-2): 131-135.

Evert-Arriagada, K., M. M. Hernández-Herrero, B. Juan, B. Guamis, B. and A. J. Trujillo. 2012. Effect of high pressure on fresh cheese shelf-life. Journal of Food Engineering, 110 (2): $248-253$. 
Extra, D. P. (2010). West's Cheese Production Bounces Back; With NM Passing MN, Region Now Has 3 Of Top 5 Cheese-Producing States, 17(1): 9-16.

Fernandes, R. (2009). Microbiology Handbook (First.). Leatherhead Food International Ltd.

Ferrentino, G., S. Balzan and S.Spilimbergo. 2013. Supercritical Carbon Dioxide Processing of Dry Cured Ham Spiked with Listeria monocytogenes: Inactivation Kinetics, Color, and Sensory Evaluations. Food and Bioprocess Technology, 6(5): 1164-1174.

Ferrentino, G., S. Balzan and S.Spilimbergo. 2013. Supercritical Carbon Dioxide Processing of Dry Cured Ham Spiked with Listeria monocytogenes: Inactivation Kinetics, Color, and Sensory Evaluations. Food and Bioprocess Technology, 6(5): 1164-1174.

Ferrentino, G., A. Belscak-Cvitanovic, D. Komes and S. Spilimbergo. 2013. Quality attributes of fresh-cut coconut after supercritical carbon dioxide pasteurization. Journal of Chemistry, 2013: 1-9.

Finazzi, G., P. Daminelli, A. Serraino, V. Pizzamiglio, R. Riu, F. Giacometti, B. Bertasi, M.N. Losio and P. Boni. 2011. Behaviour of Listeria monocytogenes in packaged water buffalo mozzarella cheese. Letters in Applied Microbiology, 53(3): 364-370.

Fleet, G. H., and M. A. Mian. 1987. The occurrence and growth of yeasts in dairy products. International Journal of Food Microbiology, 4(2): 145-155.

Flynn, D. (2014). USDA: U.S. Foodborne Illnesses Cost More Than \$15.6 Billion Annually. Retrieved April 1, 2016, from http://www.foodsafetynews.com/2014/10/foodborneillnesses-cost-usa-15-6-billion-annually/\#.VrPyq_nF-ML

Friedly, E. C., P. G. Crandall, S. Ricke, C. A. O'Bryan, E. M. Martin and L. M. Boyd. 2008. Identification of Listeria innocua surrogates for Listeria monocytogenes in hamburger patties. Journal of Food Science, 73(4): 174-178.

Gadotti, C., L. Nelson and F. Diez-Gonzalez. 2014. Inhibitory effect of combinations of caprylic acid and nisin on Listeria monocytogenes in queso fresco. Food Microbiology, 39(2014): 16.

Garcia-Gonzalez, L., A.H. Geeraerd, S. Spilimbergo, K. Elst, L. Van Ginneken, J. Debevere, J.F. Van Impe, F. Devlieghere. 2007. High pressure carbon dioxide inactivation of microorganisms in foods: The past, the present and the future. International Journal of Food Microbiology, 117(1): 1-28.

Garcia-Gonzalez, L., A.H. Geeraerd, S. Spilimbergo, K. Elst, L. Van Ginneken, J. Debevere, J.F. Van Impe, F. Devlieghere. 2009. Influence of type of microorganism, food ingredients and food properties on high-pressure carbon dioxide inactivation of microorganisms. International Journal of Food Microbiology, 129(3): 253-263.

Gardan, R., P. Cossart, T. E. L. G. Consortium and J. Labadie. 2003. Identification of Listeria monocytogenes Genes Involved in Salt and Alkaline-pH Tolerance. Applied and Environmental Microbiology. 69(6): 3137-3143. 
Gould, L. H., E. Mungai and C. B. Behravesh. 2014. Outbreaks attributed to cheese: differences between outbreaks caused by unpasteurized and pasteurized dairy products, United States, 1998-2011. Foodborne Pathogens and Disease, 11(7): 545-51.

Govaris, A. (2001). The fate of Escherichia coli O157 : H7 in Myzithra, Anthotyros, and Manouri whey cheeses during storage at 2 and $12^{\circ} \mathrm{C}$. Food Microbiology, 18(5): 565-570.

Guinee, T. P. 2004. Salting and the role of salt in cheese. International Journal of Dairy Technology, 57(2-3): 99-109.

Hargrove, R. E., F. E. McDonough and W. A. Mattingly. 1969. Factors affecting survival of Salmonella in cheddar and colby cheese. Milk Food Technology, 32, 480-484.

Havas, S., B. D. Dickinson and M. Wilson. 2009. The Urgent Need to Reduce. Journal of the American Medical Association, 298(12), 1439-1441.

He, F. , Li, J. , and G. MacGregor. 2013. Effect of longer term modest salt reduction on blood pressure: Cochrane systematic review and meta-analysis of randomised trials. Bmj-british Medical Journal, 346, f1325-f1314.

Hedberg, C. , J. Korlath, J. Daous, K. White, W. Schell, et al. 1992. A multistate outbreak of salmonella-javiana and salmonella-oranienburg infections due to consumption of contaminated cheese. Jama-journal of the American Medical Association, 268(22): 32033207.

Herrero, M. , J. Mendiola, A. Cifuentes and E. Ibáñez. 2010. Supercritical fluid extraction: Recent advances and applications. Journal of Chromatography a, 1217(16): 2495-2511.

Hong, S., and Y. Pyun. 1999. Inactivation Kinetics of Lactobacillus plantarum by High Pressure Carbon Dioxide. Science, 64(4): 728-733.

Hongmei, L., K. Zhong, X. Liao and X. Hu. 2014. Inactivation of microorganisms naturally present in raw bovine milk by high-pressure carbon dioxide. International Journal of Food Science and Technology, 49(3): 696-702.

Hotchkiss, J. H., B. G. Werner and E. Y. C. Lee. 2006. Comprehensive Reviews in Food Science and Food Safety Addition of Carbon Dioxide to Dairy Products to Improve Quality : A Comprehensive Review. Compresive Reviews in Food Science and Food Safety. 5(4): 158168.

Hystead, E., F. Diez-Gonzalez, and T. C. Schoenfuss. 2013. The effect of sodium reduction with and without potassium chloride on the survival of Listeria monocytogenes in Cheddar cheese. Journal of Dairy Science, 96(10): 6172-6185.

Ingham, S. C., Y.-C. Su and D. S. Spangenberg. 2000. Survival of Salmonella typhimurium and Escherichia coli O157:H7 in cheese brines. International Journal of Food Microbiology, 61(1): 73-79. 
Irkin, R. 2010. Determination of microbial contamination sources for use in quality management of cheese industry: "Dil" cheese as an example. Journal of Consumer Protection and Food Safety, 5(1): 91-96.

Jana, H. A., and P. K. Mandal. 2011. Manufacturing and Quality of Mozzarella Cheese A Review.pdf. International Journal of Dairy Science.

Jay, J. 1996. Modern Food Microbiology. New York: Chapman \& Hall.

Jay, J. , M. Loessner, D. Golden. 2005. Modern Food Microbiology. New York: Springer.

Johnson, M. E., R. Kapoor, D. J. McMahon, D. R. McCoy and R. G. Narasimmon. 2009. Reduction of sodium and fat levels in natural and processed cheeses: Scientific and technological aspects. Comprehensive Reviews in Food Science and Food Safety, 8(3): 252268.

Jung, W. Y., Y. M. Choi and M. S. Rhee. 2009. Potential use of supercritical carbon dioxide to decontaminate Escherichia coli O157:H7, Listeria monocytogenes, and Salmonella typhimurium in alfalfa sprouted seeds. International Journal of Food Microbiology, 136(1): 66-70.

Kabuki, D. Y., A. Y. Kuaye, M. Wiedmann and K. J. Boor. 2004. Molecular Subtyping and Tracking of Listeria monocytogenes in Latin-Style Fresh-Cheese Processing Plants. Journal of Dairy Science, 87(9): 2803-2812.

Kumari, S. 2014. Food preservation and processing. Oxford Book Company.

Keklik, N., and A. Demirci. 2009. Pulsed UV-light: Advantages for food decontamination. Resource: Engineering \& Technology for a Sustainable World, 16(5): 18.

Kim, S. A., O. Y. Kim and M. S. Rhee. 2010. Direct application of supercritical carbon dioxide for the reduction of Cronobacter spp. (Enterobacter sakazakii) in end products of dehydrated powdered infant formula. Journal of Dairy Science, 93(5), 1854-1860.

Kirtley, B. G. 2011. Lowering Sodium in Cheese: Challenges and Solution. Innovation Center for US Dairy, 1-65.

Klein, G., A. Pack, C. Bonaparte and G. Reuter. 1998. Taxonomy and physiology of probiotic lactic acid bacteria. International Journal of Food Microbiology, 41(2): 103-125.

Knez, Ž., E. Markočič, M. Leitgeb, M. Primožič, M. Knez Hrnčič, and M. Škerget, M. 2013. Industrial applications of supercritical fluids: A review. Energy, 77(2014): 235-243.

Kousta, M., M. Mataragas, P. Skandamis and E. H. Drosinos. 2010. Prevalence and sources of cheese contamination with pathogens at farm and processing levels. Food Control, 21(6): 805-815. 
Krishnamurthy, K., A.Demirci and J.M Irudayaraj. 2007. Inactivation of Staphylococcus aureus in milk using flow-through pulsed UV-light treatment system. Journal of Food Science, 72(7): M233-M239.

Larson, A. E., E. A. Johnson and J.H. Nelson. 1999. Survival of Listeria monocytogenes in commercial cheese brines. Journal of Dairy Science, 82(9): 1860-1868.

Lavieri, N. A., J. G. Sebranek, J.C. Cordray, J. S. Dickson, S. Jung, D. K. Manu, A. Mendoca, B. Brehm-Stecher, F. Byron, J. Stock and K. Stalder. 2014. Evaluation of the thin agar layer method for the recovery of pressure-injured and heat-injured Listeria monocytogenes. Journal of Food Protection, 77(5): 828-31.

Ledenbach, L. H., and R. T.Marshall. 2010. Microbial Spoilage of dairy products, p. 41-67 In Sperber, William H., Doyle, Michael P. (eds.) (ed.) Compendium of the Microbiological Spoilage of Foods and Beverages. Springer. New York, NY.

Leitner, G., N. Silanikove, S. Jacobi, L. Weisbilt, S. Ber- nstein, U. Merin. 2008. The influence of storage on the farm and in dairy silos on milk quality for cheese production. International Dairy Journal 18, 109-113.

Leong, W. , R. Geier, S. Engstrom, S. Ingham, B. Ingham and M. Smukowski. 2014. Growth of Listeria monocytogenes, Salmonella spp., Escherichia coli O157: H7, and Staphylococcus aureus on cheese during extended storage at $25^{\circ} \mathrm{C}$. Journal of Food Protection, 77(8): 1275.

Liem, D. G., F. Miremadi and R.S. J. Keast. 2011. Reducing sodium in foods: the effect on flavor. Nutrients, 3(6): 694-711.

Liu, D. 2013. Molecular approaches to the identification of pathogenic and nonpathogenic listeriae. Microbiology Insights, 2013(6): 59-69.

Lorber B. 2007. Actin-based motility and cell-to-cell spread of Listeria monocytogenes, p. 13-32. In Goldfine E., Shen H. Listeria monocytogenes: Pathogenesis and Host Response, 197233. Springer. New York, NY.

Marth, E. H. 1998. Extended shelf life refrigerated foods: Microbiological quality and safety. Food Technology, 52(2):57-62.

Mazzoni, A. M., R. R. Sharma, A. Demirci and G. R. Ziegler. 2001. Supercritical carbon dioxide treatment to inactive aerobic microorganisms on alfalfa seeds. Journal of Food Safety, 21(814), 215-223.

Mijan, M. A., M.A Haque, M. A. Habib, and M. A. Wadud. 2010. Evaluation of quality of mozzarella cheese, 27, 36-42.

Mohammadi, K., G. Karim, V. Razavilar and S. Hanifian. 2009. Study on the growth and survival of Escherichia coli $\mathrm{O} 157 \quad$ : $\mathrm{H} 7$ during the manufacture and storage of Iranian white cheese in brine. Iranian Journal of Veterinary Research, 10(4): 346-351. 
Noma, S., D. Kajiyama, N. Igura, M. Shimoda and L. Hayakawa. 2006. Mechanisms behind tailing in the pressure inactivation curve of a clinical isolate of Escherichia coli O157:H7. International Journal of Food Microbiology, 109(1-2):103-108.

Oberg, C. J., W.R. MC Manus, and D.J. Mahon. 1993. Microstructure of mozzarella cheese during manufacture. Food Structure, 12(2): 251-258.

Oh, J.-H., E. Vinay-Lara, R. McMinn, K. A. Glass, M. E. Johnson and J. L. Steele. 2014. Evaluation of $\mathrm{NaCl}, \mathrm{pH}$, and lactic acid on the growth of Shiga toxin-producing Escherichia coli in a liquid Cheddar cheese extract. Journal of Dairy Science, 97(11): 6671-6679.

Oliver, S. ., B. Jayarao, and R. Almeida. 2005. Foodborne Pathogens in Milk and the Dairy Farm Enviroment: Food Safety and Public Health Implications. Foodborne Pathogens and Disease, 2(2): 115-129.

Oussalah, M., S. Caillet, L. Saucier and M. Lacroix. 2007. Inhibitory effects of selected plant essential oils on the growth of four pathogenic bacteria: E. coli O157:H7, Salmonella Typhimurium, Staphylococcus aureus and Listeria monocytogenes. Food Control, 18(5): 414-420.

Painter, J. A., R. M. Hoekstra, T. Ayers, R.V. Tauxe, C.R. Braden, F.J. Angulo and P.M. Griffin. 2013. Attribution of foodborne illnesses, hospitalizations, and deaths to food commodities by using outbreak data, United States, 1998-2008. Emerging Infectious Diseases, 19(3):407-415.

Palmer, M. V., and S. S. T. Ting. 1995. Applications for supercritical fluid technology in food processing. Food Chemistry, 52(4): 345-352.

Panagou, E. Z., C. C. Tassou, C. Manitsa and C. Mallidis, C. 2007. Modelling the effect of high pressure on the inactivation kinetics of a pressure-resistant strain of Pediococcus damnosus in phosphate buffer and gilt-head seabream (Sparus aurata). Journal of Applied Microbiology, 102(6): 1499-1507.

Pastorino, A. J., C. L. Hansen and D. J. McMahon. 2003. Effect of salt on structure-function relationships of cheese. Journal of Dairy Science, 86(1): 60-9.

Paul, M., and D. L. Van Hekken. 2011. Short communication: Assessing antihypertensive activity in native and model Queso Fresco cheeses. Journal of Dairy Science, 94(5): 2280-2284.

Ray, B. , and A. Bhunia. 2008. Fundamental Food Microbiology. Boca Raton: CRC Press.

Reij, M. W., and E. D. Den Aantrekker. 2004. Recontamination as a source of pathogens in processed foods. International Journal of Food Microbiology, 91(1): 1-11.

Rendueles, E., M. K. Omer, O. Alvseike, C. Alonso-Calleja, R. Capita and M. Prieto. 2011. Microbiological food safety assessment of high hydrostatic pressure processing: A review. LWT - Food Science and Technology, 44(5): 1251-1260. 
Roginski, H. 2014. Moulds and Yeasts in the Dairy Industry. Paper presented at National Center for Dairy Education, Australia. Retrieved from http://www.dairyaustralia.com.au/ /media/19DE63F642E6492C89EE0673C52ECE8C.pdf. Accessed 11 June 2015.

Rozzi, N. , and R. Singh. 2002. Supercritical fluids and the food industry. Comprehensive Reviews in Food Science and Food Safety, 1(1): 33-44.

Rückerl, I., M. Muhterem-Uyar, S. Muri-Klinger, K. H. Wagner, M. Wagner and B. Stessl. 2014. L. monocytogenes in a cheese processing facility: Learning from contamination scenarios over three years of sampling. International Journal of Food Microbiology, 189 (2015): 98105 .

Saint-Eve, A., C. Lauverjat, C. Magnan, I. Déléris and I. Souchon. 2009. Reducing salt and fat content: Impact of composition, texture and cognitive interactions on the perception of flavoured model cheeses. Food Chemistry, 116(1): 167-175.

Sairam, P., S. Ghosh, S. Jena, K.N.V.Rao and D. Banji, D. 2012. Supercritical Fluid Extraction (SFE): An Overview. Asian J. Res. Pharm. Sci, 2(3): 112-120.

Samaržija, D., Š. Zamberlin, and T. Pogačić. 2012. Psychrotrophic bacteria and milk and dairy products quality. Mljekarstvo, 62(2): 77-95.

Sanaa, M., B. Poutrel, J. L. Menard and F. Serieys. 1993. Risk factors associated with contamination of raw milk by Listeria monocytogenes in dairy farms. Journal of Dairy Science, 76(10): 2891-2898.

Sánchez-Macías, D., A. Laubscher, N. Castro, A. Argüello, and R. Jiménez-Flores. 2013. Effects of supercritical fluid extraction pressure on chemical composition, microbial population, polar lipid profile, and microstructure of goat cheese. Journal of Dairy Science, 96(3): $1325-34$.

Shrestha, S. , J. Grieder, D. McMahon, and B. Nummer. 2011a. Survival of Listeria monocytogenes introduced as a post-aging contaminant during storage of low-salt Cheddar cheese at 4,10 , and $21^{\circ} \mathrm{C}$. Journal of Dairy Science, 94(9): 4329-35.

Shrestha, S. , J. Grieder, D. McMahon, and B. Nummer. 2011b. Survival of Salmonella serovars introduced as a post-aging contaminant during storage of low-salt cheddar cheese at 4, 10, and $21^{\circ} \mathrm{C}$. Journal of Food Science, 76(9): M616-M621.

Sihvonen, M., E. Järvenpää, V. Hietaniemi and R. Huopalahti. 1999. Advances in supercritical carbon dioxide technologies. Trends in Food Science and Technology, 10(6-7): 217-222.

Silva, E. N. G., Almeida, R. C. C., Figueiredo, A. C. L., \& Miranda, F. a. (2012). Effects of salts of organic acids on the survival of Listeria monocytogenes in soft cheeses. International Journal of Food Science and Technology, 47(9): 1819-1825. 
Spano, G., E. Goffredo, L. Beneduce, D. Tarantino, A. Dupuy, and S. Massa. 2003. Fate of Escherichia coli O157:H7 during the manufacture of Mozzarella cheese. Letters in Applied Microbiology, 36(2): 73-76.

Spilimbergo, S., A. Bertucco, G. Basso and G. Bertoloni. 2005. Determination of extracellular and intracellular $\mathrm{pH}$ of Bacillus subtilis suspension under $\mathrm{CO}_{2}$ treatment. Biotechnology and Bioengineering, 92(4): 447-451.

Spilimbergo, S., D. Mantoan, A. Quaranta, a., \& G. Della. Mea. 2009. Real-time monitoring of cell membrane modification during supercritical $\mathrm{CO}_{2}$ pasteurization. Journal of Supercritical Fluids, 48(1): 93-97.

Street, A., and D. Bogor. 2013. Prevalence and Sources of Contamination of Escherichia coli and Salmonella spp. in Cow Milk Dangke, Indonesian Fresh Soft Cheese Faculty of Veterinary Medicine , Bogor Agriculture University, Global Veterinaria, 11(3): 352-356.

Sulieman, A. M. E., and R.A.M. Ali. 2013. Microbiological and Sensory Quality of Mozzarella Cheese as Affected by Type of Milk and Storage. Journal of Food \& Nutritional Disorders. 2(1):1-4.

Sutherland, J. P., A. J. Bayliss and D.S. Braxton. 1995. Predictive modelling of growth of Escherichia coli O157:H7: the effects of temperature, $\mathrm{pH}$ and sodium chloride. International Journal of Food Microbiology, 25 (1995): 29-49.

Torres-Llanez, M. J., B.Vallejo-Cordoba, M.E. Díaz-Cinco, M. A. Mazorra-Manzano and A. F. González-Córdova. 2006. Characterization of the natural microflora of artisanal Mexican Fresco cheese. Food Control, 17(9): 683-690.

Uhlich, G. A, J. B. Luchansky, M. L. Tamplin, F. J. Molina-Corral, A. C. S.Anandan and PortoFett . 2006. Effect of storage temperature on the growth of Listeria monocytogenes on Queso Blanco slices. Journal of Food Safety, 26(3): 202-214.

U.S. Food and Drug Administration. 2012. Bad Bug Book: Foodborne Pathogenic Microorganisms and Natural Toxins Handbook. 2nd ed. U.S. Food and Drug Administration, Silver Spring, MD. Available at http://www.fda.gov/downloads/ Food/Foodborn eIllness Contaminants/UCM297627.pdf. Accessed 21 July 2015.

USDA. 2012. Specifications For Mozzarella Cheeses.

USDA. 2014. Dairy Products 2013 Summary, (April).

Van Hekken, D., and Farkye, N. 2003. Hispanic Cheeses: The Quest for Queso. Food Technology, 57(1):32-38.

Villar, R. , P. Hayes, L. Rowan, M. Goldoft, M. Patnode et al. 1999. Investigation of multidrugresistant salmonella serotype typhimurium DT104 infections linked to raw-milk cheese in washington state. JAMA, 281(19): 1811-1816. 
Wahi, S., S. Bansal, M. Ghosh, and A. Ganguli. 2006. Growth and survival of Escherichia coli O157:H7 during manufacture and storage of Indian cheese (paneer). Foodborne Pathogens and Disease, 3(2): 184-189.

Walther, B., and A. Schmid. 2008. Cheese in nutrition and health. Dairy Science and Technology, 88(4-5): 389-405.

Welch M.D. 2007. Actin-based motility and cell-to-cell spread of Listeria monocytogenes, pp. 42, 197-233. In Goldfine E., Shen H (ed.), Listeria monocytogenes: Pathogenesis and Host Response, 1st Ed. New York: Springer

Werner, B. G., and J.H.Hotchkiss. 2006. Continuous flow nonthermal $\mathrm{CO}_{2}$ processing: the lethal effects of subcritical and supercritical $\mathrm{CO} 2$ on total microbial populations and bacterial spores in raw milk. Journal of Dairy Science, 89(3): 872-881.

World Health Organization. 2011. Enterohaemorrhagic Escherichia coli (EHEC). Available at http://www.who.int/mediacentre/factsheets/fs125/en/. Accessed 14 July 2015.

Young Bae, Y., N. Hee Kim, K. B. Heon Kim, B. Chul Kim, B., and M. Suk Rhee. 2011. Supercritical Carbon Dioxide As a Potential Intervention for Ground Pork Decontamination. Journal of Food Safety, 31(1); 48-53.

Yuk, H.-G., Geveke, D. J., and H.Q. Zhang, H. Q. (2010). Efficacy of supercritical carbon dioxide for nonthermal inactivation of Escherichia coli K12 in apple cider. International Journal of Food Microbiology, 138(1-2):91-99.

Zottola, E. A., and L. B. Smith. 1991. Pathogens in cheese. Food Microbiology, 8(3):171-182. 


\section{APPENDICES}

\section{Appendix A: Results of Mozzarella Cheese Challenge}

Table A-1: Behavior of L. monocytogenes $(\log \mathrm{CFU} / \mathrm{g})$ in Regular and Reduced Sodium Mozzarella Cheese Stored at 4 and $12 \mathrm{C}$ on Trial 1 and Trial 2

\begin{tabular}{|c|c|c|c|c|}
\hline \multirow[b]{3}{*}{ Day } & \multicolumn{4}{|c|}{ Temperature } \\
\hline & \multicolumn{2}{|c|}{$4^{\circ} \mathrm{C}$} & \multicolumn{2}{|c|}{$12^{\circ} \mathrm{C}$} \\
\hline & Regular Sodium & Reduced Sodium & Regular Sodium & Reduced Sodium \\
\hline \multicolumn{5}{|l|}{ Day 0} \\
\hline Sample 1 & 3.54 & 3.47 & 3.54 & 3.47 \\
\hline Sample 2 & 3.34 & 3.60 & 3.34 & 3.60 \\
\hline Sample 3 & 3.31 & 3.15 & 3.31 & 3.15 \\
\hline Sample 4 & 3.14 & 3.27 & 3.14 & 3.27 \\
\hline \multicolumn{5}{|l|}{ Day 1} \\
\hline Sample 1 & 3.18 & 3.28 & 3.08 & 3.17 \\
\hline Sample 2 & 3.18 & 3.24 & 3.11 & 3.05 \\
\hline Sample 3 & 3.44 & 3.12 & 3.48 & 3.18 \\
\hline Sample 4 & 3.40 & 3.14 & 3.20 & 3.03 \\
\hline \multicolumn{5}{|l|}{ Day 3} \\
\hline Sample 1 & NT & NT & 3.15 & 3.27 \\
\hline Sample 2 & NT & NT & 3.18 & 3.24 \\
\hline Sample 3 & NT & NT & 2.48 & 2.78 \\
\hline Sample 4 & NT & NT & 3.00 & 3.18 \\
\hline \multicolumn{5}{|l|}{ Day 7} \\
\hline Sample 1 & 3.12 & 3.16 & 3.06 & 3.05 \\
\hline Sample 2 & 3.13 & 3.08 & 3.24 & 3.18 \\
\hline Sample 3 & 3.14 & 3.11 & 3.14 & 3.09 \\
\hline Sample 4 & 3.31 & 2.95 & 2.97 & 3.05 \\
\hline \multicolumn{5}{|l|}{ Day 15} \\
\hline Sample 1 & 2.81 & 2.95 & 2.87 & 3.20 \\
\hline Sample 2 & 2.75 & 3.28 & 2.95 & 3.11 \\
\hline Sample 3 & 3.05 & 3.04 & 2.70 & 2.99 \\
\hline Sample 4 & 3.01 & 3.00 & 2.49 & 3.04 \\
\hline \multicolumn{5}{|l|}{ Day 30} \\
\hline Sample 1 & 2.77 & 2.77 & 3.18 & 4.81 \\
\hline Sample 2 & 2.63 & 2.73 & 3.25 & 4.88 \\
\hline Sample 3 & 2.86 & 2.85 & 3.16 & 3.88 \\
\hline Sample 4 & 2.85 & 2.88 & 3.14 & 4.00 \\
\hline \multicolumn{5}{|l|}{ Day 60} \\
\hline Sample 1 & 2.19 & 2.47 & NT & NT \\
\hline Sample 2 & 2.23 & 2.23 & NT & NT \\
\hline Sample 3 & 2.42 & 2.51 & NT & NT \\
\hline Sample 4 & 2.53 & 2.37 & NT & NT \\
\hline \multicolumn{5}{|l|}{ Day 90} \\
\hline Sample 1 & 1.56 & 2.08 & NT & NT \\
\hline Sample 2 & 1.04 & 1.66 & NT & NT \\
\hline Sample 3 & 1.91 & 1.82 & NT & NT \\
\hline Sample 4 & 1.82 & 1.61 & NT & NT \\
\hline
\end{tabular}


Table A-2: Behavior of E. coli $\mathrm{O} 157: \mathrm{H} 7(\log \mathrm{CFU} / \mathrm{g})$ in Regular and Reduced Sodium Mozzarella Cheese Stored at 4 and $12^{\circ} \mathrm{C}$ on Trial 1 and Trial 2

\begin{tabular}{|c|c|c|c|c|}
\hline \multirow[b]{3}{*}{ Day } & \multicolumn{4}{|c|}{ Temperature } \\
\hline & \multicolumn{2}{|c|}{$4{ }^{\circ} \mathrm{C}$} & \multicolumn{2}{|c|}{$12^{\circ} \mathrm{C}$} \\
\hline & Regular Sodium & Reduced Sodium & Regular Sodium & Reduced Sodium \\
\hline \multicolumn{5}{|l|}{ Day 0} \\
\hline Sample 1 & 2.38 & 2.71 & 2.38 & 2.71 \\
\hline Sample 2 & 2.56 & 2.70 & 2.56 & 2.70 \\
\hline Sample 3 & 2.15 & 2.08 & 2.15 & 2.08 \\
\hline Sample 4 & 1.56 & 2.31 & 1.56 & 2.31 \\
\hline \multicolumn{5}{|l|}{ Day 1} \\
\hline Sample 1 & 2.32 & 2.55 & 2.26 & 2.31 \\
\hline Sample 2 & 2.03 & 2.18 & 2.53 & 2.62 \\
\hline Sample 3 & 2.84 & 2.88 & 3.02 & 3.12 \\
\hline Sample 4 & 3.15 & 2.82 & 3.16 & 3.15 \\
\hline \multicolumn{5}{|l|}{ Day 3} \\
\hline Sample 1 & NT & NT & 2.85 & 3.11 \\
\hline Sample 2 & NT & NT & 2.81 & 3.10 \\
\hline Sample 3 & NT & NT & 2.31 & 2.82 \\
\hline Sample 4 & NT & NT & 2.42 & 2.46 \\
\hline \multicolumn{5}{|l|}{ Day 7} \\
\hline Sample 1 & 2.16 & 1.91 & 2.54 & 2.75 \\
\hline Sample 2 & 2.03 & 2.21 & 2.23 & 2.40 \\
\hline Sample 3 & 1.04 & 1.04 & 1.85 & 2.19 \\
\hline Sample 4 & 0.78 & 1.32 & 2.10 & 1.32 \\
\hline \multicolumn{5}{|l|}{ Day 15} \\
\hline Sample 1 & 1.32 & 1.61 & 2.18 & 2.56 \\
\hline Sample 2 & 1.04 & 1.41 & 2.49 & 2.69 \\
\hline Sample 3 & $<1$ & 1.04 & 2.35 & 3.39 \\
\hline Sample 4 & 0.78 & $<1$ & 2.25 & 2.08 \\
\hline \multicolumn{5}{|l|}{ Day 30} \\
\hline Sample 1 & 0.30 & $<1$ & 1.71 & 1.93 \\
\hline Sample 2 & $<1$ & $<1$ & 1.91 & 1.75 \\
\hline Sample 3 & 0.78 & $<1$ & 1.96 & 1.41 \\
\hline Sample 4 & 0.78 & $<1$ & 1.56 & 1.04 \\
\hline \multicolumn{5}{|l|}{ Day 60} \\
\hline Sample 1 & 0.78 & $<1$ & NT & NT \\
\hline Sample 2 & $<1$ & $<1$ & NT & NT \\
\hline Sample 3 & $<1$ & $<1$ & NT & NT \\
\hline Sample 4 & $<1$ & $<1$ & NT & NT \\
\hline \multicolumn{5}{|l|}{ Day 90} \\
\hline Sample 1 & $<1$ & $<1$ & NT & NT \\
\hline Sample 2 & $<1$ & $<1$ & NT & NT \\
\hline Sample 3 & $<1$ & $<1$ & NT & NT \\
\hline Sample 4 & $<1$ & $<1$ & NT & NT \\
\hline
\end{tabular}


Table A-3: Behavior of Salmonella (log CFU/g) in Regular and Reduced Sodium Mozzarella Cheese Stored at 4 and $12^{\circ} \mathrm{C}$ on Trial 1 and Trial 2

\begin{tabular}{|c|c|c|c|c|}
\hline \multirow[b]{3}{*}{ Day } & \multicolumn{4}{|c|}{ Temperature } \\
\hline & \multicolumn{2}{|c|}{$4{ }^{\circ} \mathrm{C}$} & \multicolumn{2}{|c|}{$12^{\circ} \mathrm{C}$} \\
\hline & Regular Sodium & Reduced Sodium & Regular Sodium & Reduced Sodium \\
\hline \multicolumn{5}{|l|}{ Day 0} \\
\hline Sample 1 & 3.12 & 3.24 & 3.12 & 3.24 \\
\hline Sample 2 & 3.20 & 3.13 & 3.20 & 3.13 \\
\hline Sample 3 & 2.78 & 2.65 & 2.78 & 2.65 \\
\hline Sample 4 & 2.94 & 2.65 & 2.94 & 2.65 \\
\hline \multicolumn{5}{|l|}{ Day 1} \\
\hline Sample 1 & 3.12 & 3.06 & 3.16 & 3.07 \\
\hline Sample 2 & 3.21 & 2.96 & 3.00 & 3.11 \\
\hline Sample 3 & 2.62 & 2.90 & 2.61 & 2.88 \\
\hline Sample 4 & 2.80 & 2.67 & 2.81 & 2.68 \\
\hline \multicolumn{5}{|l|}{ Day 3} \\
\hline Sample 1 & NT & NT & 3.60 & 3.45 \\
\hline Sample 2 & NT & NT & 3.69 & 3.50 \\
\hline Sample 3 & NT & NT & 2.53 & 2.50 \\
\hline Sample 4 & NT & NT & 2.72 & 2.53 \\
\hline \multicolumn{5}{|l|}{ Day 7} \\
\hline Sample 1 & 2.93 & 2.48 & 2.88 & 2.81 \\
\hline Sample 2 & 2.77 & 2.42 & 2.98 & 2.76 \\
\hline Sample 3 & 1.91 & 1.56 & 2.65 & 2.12 \\
\hline Sample 4 & 2.12 & 1.79 & 2.73 & 1.93 \\
\hline \multicolumn{5}{|l|}{ Day 15} \\
\hline Sample 1 & 2.29 & 2.80 & 2.21 & 2.56 \\
\hline Sample 2 & 2.15 & 2.37 & 2.51 & 2.46 \\
\hline Sample 3 & 1.20 & 0.30 & 2.03 & 1.49 \\
\hline Sample 4 & 1.49 & 0.78 & 2.13 & 2.12 \\
\hline \multicolumn{5}{|l|}{ Day 30} \\
\hline Sample 1 & 1.79 & 0.78 & 2.15 & 1.04 \\
\hline Sample 2 & 1.20 & $<1$ & 2.25 & 1.04 \\
\hline Sample 3 & 0.78 & $<1$ & 0.78 & 0.78 \\
\hline Sample 4 & $<1$ & $<1$ & $<1$ & 0.78 \\
\hline \multicolumn{5}{|l|}{ Day 60} \\
\hline Sample 1 & $<1$ & $<1$ & NT & NT \\
\hline Sample 2 & $<1$ & $<1$ & NT & NT \\
\hline Sample 3 & $<1$ & $<1$ & NT & NT \\
\hline Sample 4 & $<1$ & $<1$ & NT & NT \\
\hline \multicolumn{5}{|l|}{ Day 90} \\
\hline Sample 1 & $<1$ & $<1$ & NT & NT \\
\hline Sample 2 & $<1$ & $<1$ & NT & NT \\
\hline Sample 3 & $<1$ & $<1$ & NT & NT \\
\hline Sample 4 & $<1$ & $<1$ & NT & NT \\
\hline
\end{tabular}


Table A-4: Behavior of Psychrotroph (log CFU/g) in Regular and Reduced Sodium Mozzarella Cheese Stored at 4 and $12^{\circ} \mathrm{C}$ on Trial 1 and Trial 2

\begin{tabular}{|c|c|c|c|c|}
\hline \multirow[b]{3}{*}{ Day } & \multicolumn{4}{|c|}{ Temperature } \\
\hline & \multicolumn{2}{|c|}{$4{ }^{\circ} \mathrm{C}$} & \multicolumn{2}{|c|}{$12^{\circ} \mathrm{C}$} \\
\hline & Regular Sodium & Reduced Sodium & Regular Sodium & Reduced Sodium \\
\hline \multicolumn{5}{|l|}{ Day 0} \\
\hline Sample 1 & 2.03 & $<1$ & 2.03 & $<1$ \\
\hline Sample 2 & 1.49 & $<1$ & 1.49 & $<1$ \\
\hline Sample 3 & 2.12 & $<1$ & 2.12 & $<1$ \\
\hline Sample 4 & 1.93 & $<1$ & 1.93 & $<1$ \\
\hline \multicolumn{5}{|l|}{ Day 1} \\
\hline Sample 1 & 1.71 & $<1$ & 3.17 & $<1$ \\
\hline Sample 2 & 1.20 & $<1$ & 3.27 & $<1$ \\
\hline Sample 3 & 3.12 & 1.04 & 2.75 & 1.32 \\
\hline Sample 4 & 1.41 & $<1$ & 2.03 & 0.78 \\
\hline \multicolumn{5}{|l|}{ Day 3} \\
\hline Sample 1 & NT & NT & 3.84 & $<1$ \\
\hline Sample 2 & NT & NT & 3.78 & $<1$ \\
\hline Sample 3 & NT & NT & 3.35 & 2.00 \\
\hline Sample 4 & NT & NT & 2.74 & 1.61 \\
\hline \multicolumn{5}{|l|}{ Day 7} \\
\hline Sample 1 & 3.90 & 1.04 & 4.41 & 1.79 \\
\hline Sample 2 & 3.85 & $<1$ & 5.02 & 1.66 \\
\hline Sample 3 & 3.06 & $<1$ & 4.35 & 3.19 \\
\hline Sample 4 & 3.84 & $<1$ & 4.46 & 2.94 \\
\hline \multicolumn{5}{|l|}{ Day 15} \\
\hline Sample 1 & 4.34 & $<1$ & 4.98 & 3.96 \\
\hline Sample 2 & 4.41 & $<1$ & 4.69 & $<1$ \\
\hline Sample 3 & 3.88 & 1.04 & 4.41 & 3.59 \\
\hline Sample 4 & 3.93 & $<1$ & 4.03 & 3.30 \\
\hline \multicolumn{5}{|l|}{ Day 30} \\
\hline Sample 1 & 5.02 & 1.20 & 5.28 & 3.80 \\
\hline Sample 2 & 4.84 & 0.00 & 5.34 & 4.13 \\
\hline Sample 3 & 5.20 & 2.30 & 4.99 & 4.17 \\
\hline Sample 4 & 5.36 & 0.00 & 4.70 & 3.06 \\
\hline \multicolumn{5}{|l|}{ Day 60} \\
\hline Sample 1 & 5.26 & 1.04 & NT & NT \\
\hline Sample 2 & 5.37 & 1.32 & NT & NT \\
\hline Sample 3 & 5.64 & 3.88 & NT & NT \\
\hline Sample 4 & 5.68 & 4.15 & NT & NT \\
\hline \multicolumn{5}{|l|}{ Day 90} \\
\hline Sample 1 & 5.56 & 4.33 & NT & NT \\
\hline Sample 2 & 5.45 & 4.38 & NT & NT \\
\hline Sample 3 & 5.30 & 5.07 & NT & NT \\
\hline Sample 4 & 5.44 & 4.77 & NT & NT \\
\hline
\end{tabular}


Table A-5: Behavior of Coliforms (log CFU/g) in Regular and Reduced Sodium Mozzarella Cheese Stored at 4 and $12^{\circ} \mathrm{C}$ on Trial 1 and Trial 2

\begin{tabular}{|c|c|c|c|c|}
\hline \multirow[b]{3}{*}{ Day } & \multicolumn{4}{|c|}{ Temperature } \\
\hline & \multicolumn{2}{|c|}{$4{ }^{\circ} \mathrm{C}$} & \multicolumn{2}{|c|}{$12^{\circ} \mathrm{C}$} \\
\hline & Regular Sodium & Reduced Sodium & Regular Sodium & Reduced Sodium \\
\hline \multicolumn{5}{|l|}{ Day 0} \\
\hline Sample 1 & 1.49 & $<1$ & 1.49 & $<1$ \\
\hline Sample 2 & $<1$ & $<1$ & $<1$ & $<1$ \\
\hline Sample 3 & $<1$ & $<1$ & $<1$ & $<1$ \\
\hline Sample 4 & $<1$ & $<1$ & $<1$ & $<1$ \\
\hline \multicolumn{5}{|l|}{ Day 1} \\
\hline Sample 1 & 1.20 & $<1$ & 0.78 & $<1$ \\
\hline Sample 2 & $<1$ & $<1$ & $<1$ & $<1$ \\
\hline Sample 3 & $<1$ & $<1$ & $<1$ & $<1$ \\
\hline Sample 4 & $<1$ & $<1$ & $<1$ & $<1$ \\
\hline \multicolumn{5}{|l|}{ Day 3} \\
\hline Sample 1 & NT & NT & $<1$ & $<1$ \\
\hline Sample 2 & NT & NT & $<1$ & $<1$ \\
\hline Sample 3 & NT & NT & $<1$ & $<1$ \\
\hline Sample 4 & NT & NT & $<1$ & $<1$ \\
\hline \multicolumn{5}{|l|}{ Day 7} \\
\hline Sample 1 & $<1$ & $<1$ & 0.18 & 1.75 \\
\hline Sample 2 & $<1$ & $<1$ & 2.53 & $<1$ \\
\hline Sample 3 & 0.78 & 2.18 & 1.04 & 1.20 \\
\hline Sample 4 & 2.00 & $<1$ & 0.78 & 1.41 \\
\hline \multicolumn{5}{|l|}{ Day 15} \\
\hline Sample 1 & 1.20 & 1.41 & $<1$ & $<1$ \\
\hline Sample 2 & 1.20 & 1.56 & $<1$ & $<1$ \\
\hline Sample 3 & $<1$ & $<1$ & $<1$ & $<1$ \\
\hline Sample 4 & $<1$ & $<1$ & $<1$ & $<1$ \\
\hline \multicolumn{5}{|l|}{ Day 30} \\
\hline Sample 1 & $<1$ & $<1$ & 2.27 & 2.00 \\
\hline Sample 2 & $<1$ & $<1$ & 0.78 & $<1$ \\
\hline Sample 3 & $<1$ & $<1$ & $<1$ & $<1$ \\
\hline Sample 4 & $<1$ & $<1$ & $<1$ & $<1$ \\
\hline \multicolumn{5}{|l|}{ Day 60} \\
\hline Sample 1 & $<1$ & $<1$ & NT & NT \\
\hline Sample 2 & $<1$ & $<1$ & NT & NT \\
\hline Sample 3 & 0.78 & 0.78 & NT & NT \\
\hline Sample 4 & 0.78 & 0.78 & NT & NT \\
\hline \multicolumn{5}{|l|}{ Day 90} \\
\hline Sample 1 & 1.56 & 2.08 & NT & NT \\
\hline Sample 2 & 1.04 & 1.66 & NT & NT \\
\hline Sample 3 & $<1$ & $<1$ & NT & NT \\
\hline Sample 4 & $<1$ & 0.78 & NT & NT \\
\hline
\end{tabular}


Table A-6: Behavior of Yeast (log CFU/g) in Regular and Reduced Sodium Mozzarella Cheese Stored at 4 and $12^{\circ} \mathrm{C}$ on Trial 1 and Trial 2

\begin{tabular}{|c|c|c|c|c|}
\hline \multirow[b]{3}{*}{ Day } & \multicolumn{4}{|c|}{ Temperature } \\
\hline & \multicolumn{2}{|c|}{$4^{\circ} \mathrm{C}$} & \multicolumn{2}{|c|}{$12{ }^{\circ} \mathrm{C}$} \\
\hline & Regular Sodium & Reduced Sodium & Regular Sodium & Reduced Sodium \\
\hline \multicolumn{5}{|l|}{ Day 0} \\
\hline Sample 1 & 1.79 & $<1$ & 1.79 & $<1$ \\
\hline Sample 2 & 2.29 & $<1$ & 2.29 & $<1$ \\
\hline Sample 3 & 1.20 & $<1$ & 1.20 & $<1$ \\
\hline Sample 4 & 1.61 & $<1$ & 1.61 & $<1$ \\
\hline \multicolumn{5}{|l|}{ Day 1} \\
\hline Sample 1 & 0.78 & $<1$ & 2.74 & $<1$ \\
\hline Sample 2 & $<1$ & $<1$ & 3.35 & $<1$ \\
\hline Sample 3 & 1.82 & 1.04 & 1.61 & 1.32 \\
\hline Sample 4 & 1.61 & $<1$ & 1.49 & 0.78 \\
\hline \multicolumn{5}{|l|}{ Day 3} \\
\hline Sample 1 & NT & NT & 3.23 & $<1$ \\
\hline Sample 2 & NT & NT & 2.83 & $<1$ \\
\hline Sample 3 & NT & NT & 2.51 & 2.55 \\
\hline Sample 4 & NT & NT & 1.75 & 2.40 \\
\hline \multicolumn{5}{|l|}{ Day 7} \\
\hline Sample 1 & 2.78 & $<1$ & 3.89 & 1.32 \\
\hline Sample 2 & 3.04 & $<1$ & 3.93 & 1.32 \\
\hline Sample 3 & 1.41 & $<1$ & 3.82 & 3.04 \\
\hline Sample 4 & 2.03 & $<1$ & 3.47 & 3.04 \\
\hline \multicolumn{5}{|l|}{ Day 15} \\
\hline Sample 1 & 3.02 & 1.41 & 4.89 & 3.85 \\
\hline Sample 2 & 3.20 & $<1$ & 4.61 & 3.65 \\
\hline Sample 3 & 3.07 & 1.04 & 4.29 & 3.51 \\
\hline Sample 4 & 3.33 & $<1$ & 3.06 & 0.00 \\
\hline \multicolumn{5}{|l|}{ Day 30} \\
\hline Sample 1 & 3.05 & 0.78 & 1.79 & $<1$ \\
\hline Sample 2 & 3.19 & $<1$ & 2.98 & $<1$ \\
\hline Sample 3 & 4.05 & 2.65 & 2.85 & 4.32 \\
\hline Sample 4 & 3.48 & 1.04 & $<1$ & 3.48 \\
\hline \multicolumn{5}{|l|}{ Day 60} \\
\hline Sample 1 & 4.27 & 1.32 & NT & NT \\
\hline Sample 2 & 5.47 & $<1$ & NT & NT \\
\hline Sample 3 & 5.23 & 3.91 & NT & NT \\
\hline Sample 4 & 5.04 & 4.13 & NT & NT \\
\hline \multicolumn{5}{|l|}{ Day 90} \\
\hline Sample 1 & 4.51 & 3.81 & NT & NT \\
\hline Sample 2 & 5.16 & 4.06 & NT & NT \\
\hline Sample 3 & 4.72 & 4.79 & NT & NT \\
\hline Sample 4 & 4.82 & 4.88 & NT & NT \\
\hline
\end{tabular}


Table A-7: Behavior of Mold (log CFU/g) in Regular and Reduced Sodium Mozzarella Cheese Stored at 4 and $12^{\circ} \mathrm{C}$ on Trial 1 and Trial 2

\begin{tabular}{|c|c|c|c|c|}
\hline \multirow[b]{3}{*}{ Day } & \multicolumn{4}{|c|}{ Temperature } \\
\hline & \multicolumn{2}{|c|}{$4^{\circ} \mathrm{C}$} & \multicolumn{2}{|c|}{$12^{\circ} \mathrm{C}$} \\
\hline & Regular Sodium & Reduced Sodium & Regular Sodium & Reduced Sodium \\
\hline \multicolumn{5}{|l|}{ Day 0} \\
\hline Sample 1 & $<1$ & $<1$ & $<1$ & $<1$ \\
\hline Sample 2 & $<1$ & $<1$ & $<1$ & $<1$ \\
\hline Sample 3 & 0.78 & 2.70 & 1.20 & 2.70 \\
\hline Sample 4 & $<1$ & $<1$ & $<1$ & $<1$ \\
\hline \multicolumn{5}{|l|}{ Day 1} \\
\hline Sample 1 & 1.32 & $<1$ & $<1$ & $<1$ \\
\hline Sample 2 & 0.78 & $<1$ & 0.78 & $<1$ \\
\hline Sample 3 & $<1$ & $<1$ & 1.71 & $<1$ \\
\hline Sample 4 & $<1$ & $<1$ & $<1$ & $<1$ \\
\hline \multicolumn{5}{|l|}{ Day 3} \\
\hline Sample 1 & NT & NT & $<1$ & $<1$ \\
\hline Sample 2 & NT & NT & $<1$ & $<1$ \\
\hline Sample 3 & NT & NT & 1.04 & $<1$ \\
\hline Sample 4 & NT & NT & 1.04 & 0.78 \\
\hline \multicolumn{5}{|l|}{ Day 7} \\
\hline Sample 1 & $<1$ & $<1$ & 1.98 & $<1$ \\
\hline Sample 2 & $<1$ & $<1$ & 2.05 & $<1$ \\
\hline Sample 3 & 0.78 & 2.18 & 2.89 & 1.04 \\
\hline Sample 4 & 2.00 & $<1$ & 2.86 & $<1$ \\
\hline \multicolumn{5}{|l|}{ Day 15} \\
\hline Sample 1 & $<1$ & $<1$ & $<1$ & $<1$ \\
\hline Sample 2 & $<1$ & $<1$ & $<1$ & $<1$ \\
\hline Sample 3 & 1.79 & $<1$ & 2.70 & 2.95 \\
\hline Sample 4 & $<1$ & $<1$ & 2.60 & 3.02 \\
\hline \multicolumn{5}{|l|}{ Day 30} \\
\hline Sample 1 & $<1$ & $<1$ & $<1$ & 4.60 \\
\hline Sample 2 & $<1$ & $<1$ & $<1$ & 5.00 \\
\hline Sample 3 & 2.00 & 1.75 & 3.90 & 5.39 \\
\hline Sample 4 & $<1$ & 0.00 & 3.97 & $<1$ \\
\hline \multicolumn{5}{|l|}{ Day 60} \\
\hline Sample 1 & 0.78 & 1.49 & NT & NT \\
\hline Sample 2 & $<1$ & $<1$ & NT & NT \\
\hline Sample 3 & 4.47 & $<1$ & NT & NT \\
\hline Sample 4 & 3.40 & $<1$ & NT & NT \\
\hline \multicolumn{5}{|l|}{ Day 90} \\
\hline Sample 1 & 5.20 & $<1$ & NT & NT \\
\hline Sample 2 & 5.36 & $<1$ & NT & NT \\
\hline Sample 3 & 3.30 & $<1$ & NT & NT \\
\hline Sample 4 & 3.60 & $<1$ & NT & NT \\
\hline
\end{tabular}


Table A-8: $\mathrm{pH}$ of Regular and Reduced Sodium Mozzarella Cheese Stored at 4 and $12^{\circ} \mathrm{C}$ on Trial 1 and Trial 2

\begin{tabular}{|c|c|c|c|c|}
\hline \multirow[b]{3}{*}{ Day } & \multicolumn{4}{|c|}{ Temperature } \\
\hline & \multicolumn{2}{|c|}{$4{ }^{\circ} \mathrm{C}$} & \multicolumn{2}{|c|}{$12^{\circ} \mathrm{C}$} \\
\hline & Regular Sodium & Reduced Sodium & Regular Sodium & Reduced Sodium \\
\hline \multicolumn{5}{|l|}{ Day 0} \\
\hline Sample 1 & 5.44 & 5.50 & 5.44 & 5.50 \\
\hline Sample 2 & 5.43 & 5.60 & 5.43 & 5.60 \\
\hline Sample 3 & 5.46 & 5.56 & 5.46 & 5.56 \\
\hline Sample 4 & 5.39 & 5.58 & 5.39 & 5.58 \\
\hline \multicolumn{5}{|l|}{ Day 1} \\
\hline Sample 1 & 5.31 & 5.28 & 5.42 & 5.41 \\
\hline Sample 2 & 5.19 & 5.36 & 5.49 & 5.30 \\
\hline Sample 3 & 5.56 & 5.58 & 5.52 & 5.49 \\
\hline Sample 4 & 5.53 & 5.53 & 5.51 & 5.41 \\
\hline \multicolumn{5}{|l|}{ Day 3} \\
\hline Sample 1 & NT & NT & 5.58 & 5.25 \\
\hline Sample 2 & NT & NT & 5.35 & 5.42 \\
\hline Sample 3 & NT & NT & 5.52 & 5.50 \\
\hline Sample 4 & NT & NT & 5.52 & 5.52 \\
\hline \multicolumn{5}{|l|}{ Day 7} \\
\hline Sample 1 & 5.38 & 5.50 & 5.33 & 5.43 \\
\hline Sample 2 & 5.46 & 5.46 & 5.07 & 5.45 \\
\hline Sample 3 & 5.61 & 5.65 & 5.63 & 5.63 \\
\hline Sample 4 & 5.61 & 5.59 & 5.58 & 5.63 \\
\hline \multicolumn{5}{|l|}{ Day 15} \\
\hline Sample 1 & 5.40 & 5.44 & 5.26 & 5.35 \\
\hline Sample 2 & 5.44 & 5.34 & 5.41 & 5.48 \\
\hline Sample 3 & 5.46 & 5.52 & 5.50 & 5.50 \\
\hline Sample 4 & 5.53 & 5.51 & 5.50 & 5.48 \\
\hline \multicolumn{5}{|l|}{ Day 30} \\
\hline Sample 1 & 5.59 & 5.58 & 5.57 & 5.55 \\
\hline Sample 2 & 5.61 & 5.60 & 5.61 & 5.55 \\
\hline Sample 3 & 5.56 & 5.56 & 5.51 & 5.49 \\
\hline Sample 4 & 5.49 & 5.54 & 5.53 & 5.49 \\
\hline \multicolumn{5}{|l|}{ Day 60} \\
\hline Sample 1 & 5.56 & 5.54 & NT & NT \\
\hline Sample 2 & 5.52 & 5.54 & NT & NT \\
\hline Sample 3 & 5.52 & 5.55 & NT & NT \\
\hline Sample 4 & 5.53 & 5.56 & NT & NT \\
\hline \multicolumn{5}{|l|}{ Day 90} \\
\hline Sample 1 & 5.51 & 5.55 & NT & NT \\
\hline Sample 2 & 5.56 & 5.58 & NT & NT \\
\hline Sample 3 & 5.54 & 5.54 & NT & NT \\
\hline Sample 4 & 5.53 & 5.51 & NT & NT \\
\hline
\end{tabular}


Table A-9: Water activity (Aw) of Regular and Reduced Sodium Mozzarella Cheese Stored at 4 and $12^{\circ} \mathrm{C}$ on Trial 1 and Trial 2

\begin{tabular}{|c|c|c|c|c|}
\hline \multirow[b]{3}{*}{ Day } & \multicolumn{4}{|c|}{ Temperature } \\
\hline & \multicolumn{2}{|c|}{$4{ }^{\circ} \mathrm{C}$} & \multicolumn{2}{|c|}{$12^{\circ} \mathrm{C}$} \\
\hline & Regular Sodium & Reduced Sodium & Regular Sodium & Reduced Sodium \\
\hline \multicolumn{5}{|l|}{ Day 0} \\
\hline Sample 1 & 0.9648 & 0.9707 & 0.9648 & 0.9707 \\
\hline Sample 2 & 0.9598 & 0.9723 & 0.9598 & 0.9723 \\
\hline Sample 3 & 0.9652 & 0.9715 & 0.9652 & 0.9715 \\
\hline Sample 4 & 0.9663 & 0.9709 & 0.9663 & 0.9709 \\
\hline \multicolumn{5}{|l|}{ Day 1} \\
\hline Sample 1 & 0.9635 & 0.9714 & 0.9687 & 0.9690 \\
\hline Sample 2 & 0.9712 & 0.9698 & 0.9567 & 0.9628 \\
\hline Sample 3 & 0.9614 & 0.9747 & 0.9657 & 0.9637 \\
\hline Sample 4 & 0.9703 & 0.9716 & 0.9644 & 0.9689 \\
\hline \multicolumn{5}{|l|}{ Day 3} \\
\hline Sample 1 & NT & NT & 0.9628 & 0.9617 \\
\hline Sample 2 & NT & NT & 0.9650 & 0.9663 \\
\hline Sample 3 & NT & NT & 0.9631 & 0.9692 \\
\hline Sample 4 & NT & NT & 0.9673 & 0.9717 \\
\hline \multicolumn{5}{|l|}{ Day 7} \\
\hline Sample 1 & 0.9663 & 0.9703 & 0.9554 & 0.9673 \\
\hline Sample 2 & 0.9677 & 0.9573 & 0.9585 & 0.9668 \\
\hline Sample 3 & 0.9618 & 0.9718 & 0.9635 & 0.9708 \\
\hline Sample 4 & 0.9665 & 0.9726 & 0.9635 & 0.9685 \\
\hline \multicolumn{5}{|l|}{ Day 15} \\
\hline Sample 1 & 0.9604 & 0.9729 & 0.9602 & 0.9727 \\
\hline Sample 2 & 0.9582 & 0.9939 & 0.9577 & 0.9712 \\
\hline Sample 3 & 0.9688 & 0.9687 & 0.9635 & 0.9787 \\
\hline Sample 4 & 0.9679 & 0.9775 & 0.9619 & 0.9742 \\
\hline \multicolumn{5}{|l|}{ Day 30} \\
\hline Sample 1 & 0.9657 & 0.9709 & 0.9721 & 0.9663 \\
\hline Sample 2 & 0.9662 & 0.9704 & 0.9653 & 0.9720 \\
\hline Sample 3 & 0.9669 & 0.9706 & 0.9642 & 0.9722 \\
\hline Sample 4 & 0.9670 & 0.9688 & 0.9640 & 0.9701 \\
\hline \multicolumn{5}{|l|}{ Day 60} \\
\hline Sample 1 & 0.9657 & 0.9680 & NT & NT \\
\hline Sample 2 & 0.9656 & 0.9688 & NT & NT \\
\hline Sample 3 & 0.9706 & 0.9740 & NT & NT \\
\hline Sample 4 & 0.9673 & 0.9738 & NT & NT \\
\hline \multicolumn{5}{|l|}{ Day 90} \\
\hline Sample 1 & 0.9627 & 0.9667 & NT & NT \\
\hline Sample 2 & 0.9645 & 0.9693 & NT & NT \\
\hline Sample 3 & 0.9607 & 0.9654 & NT & NT \\
\hline Sample 4 & 0.9669 & 0.9704 & NT & NT \\
\hline
\end{tabular}




\section{APPENDIX B: RESULTS OF SFE CHALLENGE}

Table B-1: Effect of SFE on L. innocua Population (log CFU/g) in Queso Fresco Cheese for Trial 1 and Trial 2

\begin{tabular}{|c|c|c|c|c|}
\hline \multirow[b]{2}{*}{ Storage Day } & \multirow[b]{2}{*}{ Pressure (bar) } & \multirow[b]{2}{*}{ Temperature $\left({ }^{\circ} \mathrm{C}\right)$} & \multicolumn{2}{|c|}{ L. innocua $\log \mathrm{CFU} / \mathrm{g}$} \\
\hline & & & Non-SFE & SFE \\
\hline \multicolumn{5}{|l|}{ Day 0} \\
\hline Sample 1 & 120 & 40 & 5.96 & 1.85 \\
\hline Sample 2 & 120 & 40 & 5.88 & 2.40 \\
\hline Sample 3 & 120 & 40 & 5.93 & 2.63 \\
\hline Sample 4 & 120 & 40 & 5.76 & 3.53 \\
\hline Sample 5 & 120 & 40 & 5.88 & 3.38 \\
\hline Sample 6 & 120 & 40 & 5.74 & 3.35 \\
\hline \multicolumn{5}{|l|}{ Day 1} \\
\hline Sample 1 & 120 & 40 & 5.62 & 2.89 \\
\hline Sample 2 & 120 & 40 & 5.87 & 1.32 \\
\hline Sample 3 & 120 & 40 & 5.67 & 2.92 \\
\hline Sample 4 & 120 & 40 & 5.66 & 2.70 \\
\hline Sample 5 & 120 & 40 & 5.80 & 2.86 \\
\hline Sample 6 & 120 & 40 & 5.79 & 2.99 \\
\hline \multicolumn{5}{|l|}{ Day 0} \\
\hline Sample 1 & 150 & 50 & 6.93 & 1.75 \\
\hline Sample 2 & 150 & 50 & 6.62 & 1.75 \\
\hline Sample 3 & 150 & 50 & 6.40 & 1.04 \\
\hline Sample 4 & 150 & 50 & 7.34 & 2.05 \\
\hline Sample 5 & 150 & 50 & 7.00 & 1.49 \\
\hline Sample 6 & 150 & 50 & 7.06 & 2.48 \\
\hline \multicolumn{5}{|l|}{ Day 1} \\
\hline Sample 1 & 150 & 50 & 6.95 & 1.20 \\
\hline Sample 2 & 150 & 50 & 7.02 & 2.15 \\
\hline Sample 3 & 150 & 50 & 6.99 & 1.20 \\
\hline Sample 4 & 150 & 50 & 7.15 & 1.49 \\
\hline Sample 5 & 150 & 50 & 7.46 & 1.49 \\
\hline Sample 6 & 150 & 50 & 7.23 & 1.56 \\
\hline
\end{tabular}


Table B-2: Effect of SFE on L. innocua population (log CFU/g) in Mozzarella Cheese for Trial 1 and Trial 2

\begin{tabular}{|c|c|c|c|c|}
\hline \multirow[b]{2}{*}{ Storage Day } & \multirow[b]{2}{*}{ Pressure (bar) } & \multirow[b]{2}{*}{ Temperature $\left({ }^{\circ} \mathrm{C}\right)$} & \multirow{2}{*}{$\frac{\text { L. inпосиа }}{\text { Non-SFE }}$} & \multirow{2}{*}{$\frac{\log \text { CFU/g }}{\text { SFE }}$} \\
\hline & & & & \\
\hline \multicolumn{5}{|l|}{ Day 0} \\
\hline Sample 1 & 120 & 40 & 5.59 & 2.00 \\
\hline Sample 2 & 120 & 40 & 5.99 & 1.96 \\
\hline Sample 3 & 120 & 40 & 5.83 & 1.85 \\
\hline Sample 4 & 120 & 40 & 5.88 & 3.02 \\
\hline Sample 5 & 120 & 40 & 5.80 & 1.71 \\
\hline Sample 6 & 120 & 40 & 5.92 & 2.30 \\
\hline \multicolumn{5}{|l|}{ Day 1} \\
\hline Sample 1 & 120 & 40 & 5.74 & 5.44 \\
\hline Sample 2 & 120 & 40 & 5.34 & 1.66 \\
\hline Sample 3 & 120 & 40 & 5.20 & 2.27 \\
\hline Sample 4 & 120 & 40 & 5.83 & 3.25 \\
\hline Sample 5 & 120 & 40 & 5.81 & 1.96 \\
\hline Sample 6 & 120 & 40 & 5.58 & 2.27 \\
\hline \multicolumn{5}{|l|}{ Day 8} \\
\hline Sample 1 & 120 & 40 & 5.59 & 2.18 \\
\hline Sample 2 & 120 & 40 & 5.37 & 2.36 \\
\hline Sample 3 & 120 & 40 & 5.87 & 1.98 \\
\hline Sample 4 & 120 & 40 & 5.82 & 2.03 \\
\hline Sample 5 & 120 & 40 & 5.79 & 2.03 \\
\hline Sample 6 & 120 & 40 & 5.69 & 2.75 \\
\hline \multicolumn{5}{|l|}{ Day 0} \\
\hline Sample 1 & 150 & 50 & 5.65 & 2.10 \\
\hline Sample 2 & 150 & 50 & 5.80 & 2.06 \\
\hline Sample 3 & 150 & 50 & 5.61 & 2.22 \\
\hline Sample 4 & 150 & 50 & 5.60 & 1.96 \\
\hline Sample 5 & 150 & 50 & 5.88 & 1.20 \\
\hline Sample 6 & 150 & 50 & 5.74 & 2.06 \\
\hline \multicolumn{5}{|l|}{ Day 1} \\
\hline Sample 1 & 150 & 50 & 5.59 & 2.00 \\
\hline Sample 2 & 150 & 50 & 5.71 & 1.75 \\
\hline Sample 3 & 150 & 50 & 5.54 & 1.96 \\
\hline Sample 4 & 150 & 50 & 5.72 & 2.25 \\
\hline Sample 5 & 150 & 50 & 5.62 & 1.88 \\
\hline Sample 6 & 150 & 50 & 5.69 & 1.82 \\
\hline
\end{tabular}


Table B-3: Effect of SFE on Coliforms population (log CFU/g) in Queso Fresco Cheese for Trial 1 and Trial 2

\begin{tabular}{|c|c|c|c|c|}
\hline \multirow[b]{2}{*}{ Storage Day } & \multirow[b]{2}{*}{ Pressure (bar) } & \multirow[b]{2}{*}{ Temperature $\left({ }^{\circ} \mathrm{C}\right)$} & \multicolumn{2}{|c|}{ Coliforms $\quad \log \mathrm{CFU} / \mathrm{g}$} \\
\hline & & & Non-SFE & SFE \\
\hline \multicolumn{5}{|l|}{ Day 0} \\
\hline Sample 1 & 120 & 40 & 5.81 & 2.00 \\
\hline Sample 2 & 120 & 40 & 6.02 & $<1$ \\
\hline Sample 3 & 120 & 40 & 6.25 & $<1$ \\
\hline Sample 4 & 120 & 40 & 3.10 & $<1$ \\
\hline Sample 5 & 120 & 40 & 3.24 & $<1$ \\
\hline Sample 6 & 120 & 40 & 2.74 & $<1$ \\
\hline \multicolumn{5}{|l|}{ Day 1} \\
\hline Sample 1 & 120 & 40 & 6.56 & 1.71 \\
\hline Sample 2 & 120 & 40 & 6.99 & $<1$ \\
\hline Sample 3 & 120 & 40 & 6.74 & $<1$ \\
\hline Sample 4 & 120 & 40 & 4.14 & 1.71 \\
\hline Sample 5 & 120 & 40 & 4.14 & 1.32 \\
\hline Sample 6 & 120 & 40 & 3.54 & 1.32 \\
\hline \multicolumn{5}{|l|}{ Day 0} \\
\hline Sample 1 & 150 & 50 & 6.93 & $<1$ \\
\hline Sample 2 & 150 & 50 & 6.87 & $<1$ \\
\hline Sample 3 & 150 & 50 & 6.83 & $<1$ \\
\hline Sample 4 & 150 & 50 & 7.61 & 2.80 \\
\hline Sample 5 & 150 & 50 & 7.80 & 3.12 \\
\hline Sample 6 & 150 & 50 & 8.19 & 2.61 \\
\hline \multicolumn{5}{|l|}{ Day 1} \\
\hline Sample 1 & 150 & 50 & 7.68 & $<1$ \\
\hline Sample 2 & 150 & 50 & 7.34 & $<1$ \\
\hline Sample 3 & 150 & 50 & 7.35 & $<1$ \\
\hline Sample 4 & 150 & 50 & 7.78 & 4.82 \\
\hline Sample 5 & 150 & 50 & 7.89 & 4.66 \\
\hline Sample 6 & 150 & 50 & 8.01 & 4.44 \\
\hline
\end{tabular}


Table B-4: Effect of SFE on Psychrotroph population (log CFU/g) in Queso Fresco Cheese for Trial 1 and Trial 2

\begin{tabular}{|c|c|c|c|c|}
\hline \multirow[b]{2}{*}{ Storage Day } & \multirow[b]{2}{*}{ Pressure (bar) } & \multirow[b]{2}{*}{ Temperature $\left({ }^{\circ} \mathrm{C}\right)$} & \multirow{2}{*}{$\begin{array}{c}\text { Psychrotroph } \\
\text { Non-SFE }\end{array}$} & \multirow{2}{*}{$\begin{array}{r}\log \mathrm{CFU} / \mathrm{g} \\
\mathrm{SFE}\end{array}$} \\
\hline & & & & \\
\hline \multicolumn{5}{|l|}{ Day 0} \\
\hline Sample 1 & 120 & 40 & 6.83 & 1.85 \\
\hline Sample 2 & 120 & 40 & 6.53 & 2.85 \\
\hline Sample 3 & 120 & 40 & 6.77 & 2.08 \\
\hline Sample 4 & 120 & 40 & 6.69 & 4.41 \\
\hline Sample 5 & 120 & 40 & 6.34 & 4.40 \\
\hline Sample 6 & 120 & 40 & 6.68 & 4.38 \\
\hline \multicolumn{5}{|l|}{ Day 1} \\
\hline Sample 1 & 120 & 40 & 6.93 & 2.98 \\
\hline Sample 2 & 120 & 40 & 6.97 & 2.31 \\
\hline Sample 3 & 120 & 40 & 7.05 & 2.15 \\
\hline Sample 4 & 120 & 40 & 7.03 & 5.22 \\
\hline Sample 5 & 120 & 40 & 7.06 & 4.83 \\
\hline Sample 6 & 120 & 40 & -- & 5.13 \\
\hline \multicolumn{5}{|l|}{ Day 0} \\
\hline Sample 1 & 150 & 50 & 6.92 & 2.65 \\
\hline Sample 2 & 150 & 50 & 7.02 & 1.20 \\
\hline Sample 3 & 150 & 50 & 7.08 & $<1$ \\
\hline Sample 4 & 150 & 50 & 7.88 & 2.28 \\
\hline Sample 5 & 150 & 50 & 7.65 & 1.41 \\
\hline Sample 6 & 150 & 50 & 7.49 & 3.12 \\
\hline \multicolumn{5}{|l|}{ Day 1} \\
\hline Sample 1 & 150 & 50 & 7.91 & 1.56 \\
\hline Sample 2 & 150 & 50 & 8.00 & $<1$ \\
\hline Sample 3 & 150 & 50 & 7.85 & $<1$ \\
\hline Sample 4 & 150 & 50 & 7.62 & $<1$ \\
\hline Sample 5 & 150 & 50 & 7.40 & $<1$ \\
\hline Sample 6 & 150 & 50 & 7.24 & 1.93 \\
\hline
\end{tabular}


Table B-5: Effect of SFE on Yeast population (log CFU/g) in Queso Fresco Cheese for Trial 1 and Trial 2

\begin{tabular}{|c|c|c|c|c|}
\hline \multirow[b]{2}{*}{ Storage Day } & \multirow[b]{2}{*}{ Pressure (bar) } & \multirow[b]{2}{*}{ Temperature $\left({ }^{\circ} \mathrm{C}\right)$} & \multicolumn{2}{|c|}{ Yeast $\log$ CFU/g } \\
\hline & & & Non-SFE & SFE \\
\hline \multicolumn{5}{|l|}{ Day 0} \\
\hline Sample 1 & 120 & 40 & 2.15 & 1.20 \\
\hline Sample 2 & 120 & 40 & 2.47 & $<1$ \\
\hline Sample 3 & 120 & 40 & 2.05 & $<1$ \\
\hline Sample 4 & 120 & 40 & 2.59 & $<1$ \\
\hline Sample 5 & 120 & 40 & 2.65 & $<1$ \\
\hline Sample 6 & 120 & 40 & 1.82 & $<1$ \\
\hline \multicolumn{5}{|l|}{ Day 1} \\
\hline Sample 1 & 120 & 40 & 2.73 & $<1$ \\
\hline Sample 2 & 120 & 40 & 3.00 & $<1$ \\
\hline Sample 3 & 120 & 40 & 2.23 & $<1$ \\
\hline Sample 4 & 120 & 40 & 2.76 & $<1$ \\
\hline Sample 5 & 120 & 40 & 1.20 & $<1$ \\
\hline Sample 6 & 120 & 40 & 3.00 & $<1$ \\
\hline \multicolumn{5}{|l|}{ Day 0} \\
\hline Sample 1 & 150 & 50 & 2.19 & $<1$ \\
\hline Sample 2 & 150 & 50 & 2.39 & $<1$ \\
\hline Sample 3 & 150 & 50 & 2.05 & $<1$ \\
\hline Sample 4 & 150 & 50 & 1.82 & $<1$ \\
\hline Sample 5 & 150 & 50 & 2.80 & $<1$ \\
\hline Sample 6 & 150 & 50 & 3.04 & $<1$ \\
\hline \multicolumn{5}{|l|}{ Day 1} \\
\hline Sample 1 & 150 & 50 & 1.91 & 0.78 \\
\hline Sample 2 & 150 & 50 & 2.40 & $<1$ \\
\hline Sample 3 & 150 & 50 & 2.06 & $<1$ \\
\hline Sample 4 & 150 & 50 & 1.75 & $<1$ \\
\hline Sample 5 & 150 & 50 & 2.85 & $<1$ \\
\hline Sample 6 & 150 & 50 & 1.79 & $<1$ \\
\hline
\end{tabular}


Table B-6: Effect of SFE on the pH of Queso Fresco Cheese for Trial 1 and Trial 2

\begin{tabular}{|c|c|c|c|c|}
\hline \multirow[b]{2}{*}{ Storage Day } & \multirow[b]{2}{*}{ Pressure (bar) } & \multirow[b]{2}{*}{ Temperature $\left({ }^{\circ} \mathrm{C}\right)$} & \multicolumn{2}{|c|}{$\begin{array}{c}\text { Queso Fresco } \\
p H\end{array}$} \\
\hline & & & Non-SFE & SFE \\
\hline \multicolumn{5}{|l|}{ Day 0} \\
\hline Sample 1 & 120 & 40 & 6.61 & 6.54 \\
\hline Sample 2 & 120 & 40 & 6.61 & 6.55 \\
\hline Sample 3 & 120 & 40 & 6.60 & 6.60 \\
\hline Sample 4 & 120 & 40 & 6.53 & 6.32 \\
\hline Sample 5 & 120 & 40 & 6.54 & 6.33 \\
\hline Sample 6 & 120 & 40 & 6.55 & 6.41 \\
\hline \multicolumn{5}{|l|}{ Day 1} \\
\hline Sample 1 & 120 & 40 & 6.76 & 6.59 \\
\hline Sample 2 & 120 & 40 & 6.74 & 6.60 \\
\hline Sample 3 & 120 & 40 & 6.74 & 6.59 \\
\hline Sample 4 & 120 & 40 & 6.72 & 6.60 \\
\hline Sample 5 & 120 & 40 & 6.74 & 6.60 \\
\hline Sample 6 & 120 & 40 & 6.73 & 6.56 \\
\hline \multicolumn{5}{|l|}{ Day 0} \\
\hline Sample 1 & 150 & 50 & 6.67 & 6.56 \\
\hline Sample 2 & 150 & 50 & 6.64 & 6.55 \\
\hline Sample 3 & 150 & 50 & 6.68 & 6.62 \\
\hline Sample 4 & 150 & 50 & 6.60 & 6.42 \\
\hline Sample 5 & 150 & 50 & 6.56 & 6.41 \\
\hline Sample 6 & 150 & 50 & 6.59 & 6.42 \\
\hline \multicolumn{5}{|l|}{ Day 1} \\
\hline Sample 1 & 150 & 50 & 6.71 & 6.50 \\
\hline Sample 2 & 150 & 50 & 6.69 & 6.59 \\
\hline Sample 3 & 150 & 50 & 6.68 & 6.49 \\
\hline Sample 4 & 150 & 50 & 6.58 & 6.5 \\
\hline Sample 5 & 150 & 50 & 6.61 & 6.42 \\
\hline Sample 6 & 150 & 50 & 6.62 & 6.43 \\
\hline
\end{tabular}


Table B-7: Effect of SFE on the pH of Mozzarella Cheese for Trial 1 and Trial 2

\begin{tabular}{|c|c|c|c|c|}
\hline \multirow[b]{2}{*}{ Storage Day } & \multirow[b]{2}{*}{ Pressure (bar) } & \multirow[b]{2}{*}{ Temperature $\left({ }^{\circ} \mathrm{C}\right)$} & \multicolumn{2}{|c|}{ Mozzarella pH } \\
\hline & & & Non-SFE & SFE \\
\hline \multicolumn{5}{|l|}{ Day 0} \\
\hline Sample 1 & 120 & 40 & 5.24 & 5.28 \\
\hline Sample 2 & 120 & 40 & 5.25 & 5.24 \\
\hline Sample 3 & 120 & 40 & 5.31 & 5.28 \\
\hline Sample 4 & 120 & 40 & 5.17 & 5.16 \\
\hline Sample 5 & 120 & 40 & 5.15 & 5.16 \\
\hline Sample 6 & 120 & 40 & 5.18 & 5.18 \\
\hline \multicolumn{5}{|l|}{ Day 1} \\
\hline Sample 1 & 120 & 40 & 5.18 & 5.19 \\
\hline Sample 2 & 120 & 40 & 5.20 & 5.18 \\
\hline Sample 3 & 120 & 40 & 5.17 & 5.21 \\
\hline Sample 4 & 120 & 40 & 5.16 & 5.15 \\
\hline Sample 5 & 120 & 40 & 5.16 & 5.17 \\
\hline Sample 6 & 120 & 40 & 5.16 & 5.18 \\
\hline \multicolumn{5}{|l|}{ Day 8} \\
\hline Sample 1 & 120 & 40 & 5.23 & 5.25 \\
\hline Sample 2 & 120 & 40 & 5.24 & 5.22 \\
\hline Sample 3 & 120 & 40 & 5.25 & 5.25 \\
\hline Sample 4 & 120 & 40 & 5.14 & 5.09 \\
\hline Sample 5 & 120 & 40 & 5.16 & 5.1 \\
\hline Sample 6 & 120 & 40 & 5.12 & 5.14 \\
\hline \multicolumn{5}{|l|}{ Day 0} \\
\hline Sample 1 & 150 & 50 & 5.37 & 5.37 \\
\hline Sample 2 & 150 & 50 & 5.37 & 5.32 \\
\hline Sample 3 & 150 & 50 & 5.32 & 5.35 \\
\hline Sample 4 & 150 & 50 & 5.30 & 5.36 \\
\hline Sample 5 & 150 & 50 & 5.29 & 5.33 \\
\hline Sample 6 & 150 & 50 & 5.31 & 5.33 \\
\hline \multicolumn{5}{|l|}{ Day 1} \\
\hline Sample 1 & 150 & 50 & 5.34 & 5.33 \\
\hline Sample 2 & 150 & 50 & 5.36 & 5.37 \\
\hline Sample 3 & 150 & 50 & 5.34 & 5.38 \\
\hline Sample 4 & 150 & 50 & 5.50 & 5.48 \\
\hline Sample 5 & 150 & 50 & 5.52 & 5.50 \\
\hline Sample 6 & 150 & 50 & 5.55 & 5.51 \\
\hline
\end{tabular}


Table B-8: Effect of SFE on the Water Activity (Aw) of Queso Fresco Cheese Trial 1 and Trial 2

\begin{tabular}{|c|c|c|c|c|}
\hline \multirow[b]{2}{*}{ Storage Day } & \multirow[b]{2}{*}{ Pressure (bar) } & \multicolumn{3}{|c|}{$\begin{array}{c}\text { Queso Fresco } \\
A w\end{array}$} \\
\hline & & Temperature $\left({ }^{\circ} \mathrm{C}\right)$ & Non-SFE & SFE \\
\hline \multicolumn{5}{|l|}{ Day 0} \\
\hline Sample 1 & 120 & 40 & 0.9759 & 0.9747 \\
\hline Sample 2 & 120 & 40 & 0.9788 & 0.9743 \\
\hline Sample 3 & 120 & 40 & 0.9758 & 0.9717 \\
\hline Sample 4 & 120 & 40 & 0.9715 & 0.9708 \\
\hline Sample 5 & 120 & 40 & 0.9675 & 0.9693 \\
\hline Sample 6 & 120 & 40 & 0.9726 & 0.9697 \\
\hline \multicolumn{5}{|l|}{ Day 1} \\
\hline Sample 1 & 120 & 40 & 0.9611 & 0.9620 \\
\hline Sample 2 & 120 & 40 & 0.9654 & 0.9602 \\
\hline Sample 3 & 120 & 40 & 0.9703 & 0.9599 \\
\hline Sample 4 & 120 & 40 & 0.9689 & 0.9711 \\
\hline Sample 5 & 120 & 40 & 0.9700 & 0.9692 \\
\hline Sample 6 & 120 & 40 & 0.9697 & 0.9708 \\
\hline \multicolumn{5}{|l|}{ Day 0} \\
\hline Sample 1 & 150 & 50 & 0.9772 & 0.9700 \\
\hline Sample 2 & 150 & 50 & 0.9764 & 0.9715 \\
\hline Sample 3 & 150 & 50 & 0.9723 & 0.9752 \\
\hline Sample 4 & 150 & 50 & 0.9794 & 0.9811 \\
\hline Sample 5 & 150 & 50 & 0.9804 & 0.9789 \\
\hline Sample 6 & 150 & 50 & 0.9736 & 0.9790 \\
\hline \multicolumn{5}{|l|}{ Day 1} \\
\hline Sample 1 & 150 & 50 & 0.9751 & 0.9678 \\
\hline Sample 2 & 150 & 50 & 0.9715 & 0.9693 \\
\hline Sample 3 & 150 & 50 & 0.9745 & 0.9684 \\
\hline Sample 4 & 150 & 50 & 0.9804 & 0.9787 \\
\hline Sample 5 & 150 & 50 & 0.9747 & 0.9803 \\
\hline Sample 6 & 150 & 50 & 0.9797 & 0.9778 \\
\hline
\end{tabular}


Table B-9: Effect of SFE on the Water Activity (Aw) of Mozzarella Cheese Trial 1 and Trial 2

\begin{tabular}{|c|c|c|c|c|}
\hline & & \multicolumn{3}{|c|}{ Mozzarella Aw } \\
\hline Storage Day & Pressure (bar) & Temperature $\left({ }^{\circ} \mathrm{C}\right)$ & Non-SFE & SFE \\
\hline \multicolumn{5}{|l|}{ Day 0} \\
\hline Sample 1 & 120 & 40 & 0.9484 & 0.9526 \\
\hline Sample 2 & 120 & 40 & 0.9575 & 0.9520 \\
\hline Sample 3 & 120 & 40 & 0.9611 & 0.9533 \\
\hline Sample 4 & 120 & 40 & 0.9600 & 0.9546 \\
\hline Sample 5 & 120 & 40 & 0.9579 & 0.9550 \\
\hline Sample 6 & 120 & 40 & 0.9583 & 0.9514 \\
\hline \multicolumn{5}{|l|}{ Day 1} \\
\hline Sample 1 & 120 & 40 & 0.9556 & 0.9586 \\
\hline Sample 2 & 120 & 40 & 0.9589 & 0.9583 \\
\hline Sample 3 & 120 & 40 & 0.9518 & 0.9592 \\
\hline Sample 4 & 120 & 40 & 0.9526 & 0.9559 \\
\hline Sample 5 & 120 & 40 & 0.9527 & 0.9536 \\
\hline Sample 6 & 120 & 40 & 0.9600 & 0.9516 \\
\hline \multicolumn{5}{|l|}{ Day 8} \\
\hline Sample 1 & 120 & 40 & 0.9582 & 0.9667 \\
\hline Sample 2 & 120 & 40 & 0.9572 & 0.954 \\
\hline Sample 3 & 120 & 40 & 0.9537 & 0.9524 \\
\hline Sample 4 & 120 & 40 & 0.969 & 0.9567 \\
\hline Sample 5 & 120 & 40 & 0.96 & 0.9598 \\
\hline Sample 6 & 120 & 40 & 0.9578 & 0.9563 \\
\hline \multicolumn{5}{|l|}{ Day 0} \\
\hline Sample 1 & 150 & 50 & 0.9595 & 0.9603 \\
\hline Sample 2 & 150 & 50 & 0.9626 & 0.9663 \\
\hline Sample 3 & 150 & 50 & 0.9682 & 0.9689 \\
\hline Sample 4 & 150 & 50 & 0.9634 & 0.9644 \\
\hline Sample 5 & 150 & 50 & 0.9623 & 0.9601 \\
\hline Sample 6 & 150 & 50 & 0.9689 & 0.9634 \\
\hline \multicolumn{5}{|l|}{ Day 1} \\
\hline Sample 1 & 150 & 50 & 0.9696 & 0.9549 \\
\hline Sample 2 & 150 & 50 & 0.9685 & 0.9528 \\
\hline Sample 3 & 150 & 50 & 0.9642 & 0.9551 \\
\hline Sample 4 & 150 & 50 & 0.9630 & 0.9561 \\
\hline Sample 5 & 150 & 50 & 0.9642 & 0.9527 \\
\hline
\end{tabular}




\section{APPENDIX C: SFE PROCESSING INFORMATION OF EACH TRIAL}

This appendix contains the time, pressure, and temperature during SFE processing. The time needed to reach the holding time parameter is equal to the time before reaching a stable temperature and pressure before holding the cheeses samples for 30 minutes at 120 bar with $40^{\circ} \mathrm{C}$ or 150 bar with $50^{\circ} \mathrm{C}$. It also includes the depressurization time for each trial. Pictures of the SFE equipment are also included.

Table C-1: Mozzarella Cheese Treated with SFE at 120 bar, $40^{\circ} \mathrm{C}$ for 30 minutes for Trial 1

Time needed to reach
holding time (min)
parameters:

\begin{tabular}{ccccc}
\hline \multicolumn{2}{c}{ Holding time } & & & \\
\hline $\begin{array}{c}\text { Vessel Temperature } \\
\left({ }^{\circ} \mathrm{C}\right)\end{array}$ & $\begin{array}{c}\text { Oven temperature } \\
\left({ }^{\circ} \mathrm{C}\right)\end{array}$ & $\begin{array}{c}\text { Restrictor temperature } \\
\left({ }^{\circ} \mathrm{C}\right)\end{array}$ & $\begin{array}{c}\text { Pressure } \\
(\mathrm{bar})\end{array}$ & $\begin{array}{c}\text { Holding time } \\
(\mathrm{min})\end{array}$ \\
\hline 40 & 40 & 119 & 120 & 0 \\
39 & 41 & 119 & 120.4 & 12 \\
39.3 & 44 & 120 & 120.4 & 15 \\
40.1 & 43 & 124 & 120.5 & 20 \\
39 & 39 & 121 & 119.6 & 25 \\
39.4 & 40 & 121 & 122.6 & 27 \\
40 & 45 & 120 & 121.4 & 30 \\
\hline
\end{tabular}

Depressurization time (min): 
Table C-2: Mozzarella Cheese treated with SFE at 120 Bar, $40^{\circ} \mathrm{C}$ for 30 minutes for Trial 2

Time to needed to

reach holding time

30

(min) parameters

Holding time

\begin{tabular}{ccccc}
\hline $\begin{array}{c}\text { Vessel Temperature } \\
\left({ }^{\circ} \mathrm{C}\right)\end{array}$ & $\begin{array}{c}\text { Oven temperature } \\
\left({ }^{\circ} \mathrm{C}\right)\end{array}$ & $\begin{array}{c}\text { Restrictor temperature } \\
\left({ }^{\circ} \mathrm{C}\right)\end{array}$ & $\begin{array}{c}\text { Pressure } \\
(\text { bar })\end{array}$ & $\begin{array}{c}\text { Holding time } \\
(\mathrm{min})\end{array}$ \\
\hline 40 & 40 & 119 & 120 & 0 \\
39.3 & 40 & 120 & 120.2 & 10 \\
39.3 & 42 & 120 & 122.2 & 13 \\
38.7 & 42 & 120 & 119.7 & 16 \\
41.2 & 44 & 120 & 120 & 20 \\
41.5 & 43 & 121 & 120.2 & 25 \\
41.3 & 42 & 121 & 120 & 29 \\
41.2 & 42 & 121 & 119.8 & 30 \\
\hline
\end{tabular}

Depressurization time (min):

25

Table C-3: Mozzarella Cheese Treated with SFE at 150 Bar, $50^{\circ} \mathrm{C}$ for 30 minutes for Trial 1

Time to needed to reach holding time (min) parameters

\begin{tabular}{ccccc}
\hline Holding time & & & \\
\hline Vessel Temperature $\left({ }^{\circ} \mathrm{C}\right)$ & $\begin{array}{c}\text { Oven } \\
\text { temperature } \\
\left({ }^{\circ} \mathrm{C}\right)\end{array}$ & $\begin{array}{c}\text { Restrictor } \\
\text { temperature }\left({ }^{\circ} \mathrm{C}\right)\end{array}$ & $\begin{array}{c}\text { Pressure } \\
(\text { bar })\end{array}$ & $\begin{array}{c}\text { Holding } \\
\text { time } \\
(\min )\end{array}$ \\
\hline 52.6 & 54 & 120 & 150.9 & 0 \\
52.1 & 53 & 120 & 151.1 & 5 \\
51.5 & 52 & 120 & 150 & 10 \\
50.9 & 51 & 120 & 150.2 & 15 \\
50.2 & 51 & 120 & 150 & 20 \\
49.6 & 50 & 121 & 150 & 25 \\
49.4 & 50 & 120 & 150.1 & 28 \\
49.1 & 49 & 120 & 150.1 & 30 \\
\hline
\end{tabular}

40 minutes

Holding time temperature

53

40 
Table C-4: Mozzarella Cheese treated with SFE at 150 bar, $50^{\circ} \mathrm{C}$ for 30 minutes for trial 2

Time needed to reach holding time $(\mathrm{min}) \quad 40$ minutes parameters

\begin{tabular}{ccccc}
\hline \multicolumn{1}{c}{ Holding time } & & & \\
\hline $\begin{array}{c}\text { Vessel Temperature } \\
\left({ }^{\circ} \mathrm{C}\right)\end{array}$ & $\begin{array}{c}\text { Oven temperature } \\
\left({ }^{\circ} \mathrm{C}\right)\end{array}$ & $\begin{array}{c}\text { Restrictor temperature } \\
\left({ }^{\circ} \mathrm{C}\right)\end{array}$ & $\begin{array}{c}\text { Pressure } \\
(\text { bar })\end{array}$ & $\begin{array}{c}\text { Holding time } \\
(\min )\end{array}$ \\
\hline 47.5 & 49 & 121 & 150 & 0 \\
47 & 48 & 120 & 149.7 & 5 \\
48.9 & 54 & 121 & 154.6 & 10 \\
50.2 & 52 & 120 & 150.4 & 15 \\
49.8 & 51 & 120 & 149.9 & 20 \\
48.9 & 50 & 120 & 149.9 & 25 \\
48.6 & 50 & 120 & 150 & 28 \\
48.2 & 49 & 120 & 149.9 & 30 \\
\hline
\end{tabular}

Depressurization time (min):

15

Table C-5: Queso Fresco Cheese treated with SFE at 120 bar, $40^{\circ} \mathrm{C}$ for 30 minutes for trial 1

Time needed to reach

holding time ( $\mathrm{min}$ ) 23 parameters

\begin{tabular}{ccccc}
\hline $\begin{array}{c}\text { Vessel Temperature } \\
\left({ }^{\circ} \mathrm{C}\right)\end{array}$ & $\begin{array}{c}\text { Oven temperature } \\
\left({ }^{\circ} \mathrm{C}\right)\end{array}$ & $\begin{array}{c}\text { Restrictor temperature } \\
\left({ }^{\circ} \mathrm{C}\right)\end{array}$ & $\begin{array}{c}\text { Pressure } \\
(\text { bar })\end{array}$ & $\begin{array}{c}\text { Holding time } \\
(\mathrm{min})\end{array}$ \\
\hline 42.6 & 46 & 120 & 120.8 & 0 \\
42.8 & 44 & 120 & 120.1 & 5 \\
41.9 & 43 & 120 & 120 & 10 \\
41.2 & 42 & 121 & 120 & 15 \\
40.8 & 41 & 121 & 119.9 & 20 \\
40.2 & 41 & 120 & 119.8 & 15 \\
40 & 40 & 121 & 120 & 27 \\
39.6 & 40 & 120 & 120.1 & 30 \\
\hline
\end{tabular}

Depressurization time $(\min )$ : 
Table C-6: Queso Fresco Cheese Treated with SFE at 120 Bar, $40^{\circ} \mathrm{C}$ for 30 minutes for Trial 2

\begin{tabular}{|c|c|c|c|c|}
\hline $\begin{array}{l}\text { Time needed to reach } \\
\text { holding time (min) } \\
\text { parameters }\end{array}$ & 31 & & & \\
\hline \multicolumn{5}{|c|}{ Holding time } \\
\hline $\begin{array}{l}\text { Vessel Temperature } \\
\left({ }^{\circ} \mathrm{C}\right)\end{array}$ & $\begin{array}{c}\text { Oven temperature } \\
\left({ }^{\circ} \mathrm{C}\right)\end{array}$ & $\begin{array}{l}\text { Restrictor temperature } \\
\left({ }^{\circ} \mathrm{C}\right)\end{array}$ & $\begin{array}{l}\text { Pressure } \\
\text { (bar) }\end{array}$ & $\begin{array}{l}\text { Holding time } \\
\text { (min) }\end{array}$ \\
\hline 40.5 & 37 & 120 & 120.1 & 0 \\
\hline 40.1 & 37 & 121 & 120.2 & 5 \\
\hline 39.4 & 37 & 120 & 119.9 & 15 \\
\hline 39.1 & 37 & 121 & 119.8 & 20 \\
\hline 38.8 & 36 & 121 & 119.9 & 25 \\
\hline 38.6 & 36 & 120 & 120.2 & 30 \\
\hline $\begin{array}{l}\text { Depressurization time } \\
\text { (min): }\end{array}$ & 23 & & & \\
\hline
\end{tabular}

Table C-7: Queso Fresco Cheese Treated with SFE at $150 \mathrm{Bar}, 50^{\circ} \mathrm{C}$ for 30 minutes for Trial 1

Time needed to reach

holding time ( $\mathrm{min})$ parameters

\begin{tabular}{ccccc} 
parameters & \multicolumn{3}{c}{} \\
\hline $\begin{array}{c}\text { Vessel Temperature } \\
\left({ }^{\circ} \mathrm{C}\right)\end{array}$ & $\begin{array}{c}\text { Oven temperature } \\
\left({ }^{\circ} \mathrm{C}\right)\end{array}$ & $\begin{array}{c}\text { Restrictor temperature } \\
\left({ }^{\circ} \mathrm{C}\right)\end{array}$ & $\begin{array}{c}\text { Pressure } \\
(\mathrm{bar})\end{array}$ & $\begin{array}{c}\text { Holding time } \\
(\mathrm{min})\end{array}$ \\
\hline 47.8 & 50 & 120 & 150.1 & 0 \\
47.4 & 49 & 120 & 150.2 & 5 \\
47.3 & 50 & 120 & 142.4 & 10 \\
50 & 54 & 120 & 152 & 15 \\
49.7 & 51 & 120 & 149.6 & 20 \\
49 & 50 & 120 & 149.9 & 25 \\
48.3 & 49 & 120 & 150.1 & 30 \\
\hline
\end{tabular}

Depressurization time $(\min )$ : 
Table C-8: Queso Fresco Cheese Treated with SFE at 150 bar, $50^{\circ} \mathrm{C}$ for 30 minutes for Trial 2

Time needed to reach
holding time (min)

parameters

\begin{tabular}{ccccc}
\hline \multicolumn{5}{c}{ Holding time } \\
\hline $\begin{array}{c}\text { Vessel Temperature } \\
\left({ }^{\circ} \mathrm{C}\right)\end{array}$ & $\begin{array}{c}\text { Oven temperature } \\
\left({ }^{\circ} \mathrm{C}\right)\end{array}$ & $\begin{array}{c}\text { Restrictor temperature } \\
\left({ }^{\circ} \mathrm{C}\right)\end{array}$ & $\begin{array}{c}\text { Pressure } \\
(\mathrm{bar})\end{array}$ & $\begin{array}{c}\text { Holding time } \\
(\mathrm{min})\end{array}$ \\
\hline 51 & 54 & 120 & 150 & 0 \\
50.2 & 52 & 120 & 150 & 5 \\
49.6 & 51 & 121 & 149.8 & 10 \\
48.9 & 50 & 120 & 150.2 & 15 \\
48.2 & 49 & 120 & 149.8 & 20 \\
48.7 & 50 & 121 & 151.5 & 25 \\
48.3 & 49 & 120 & 149.6 & 30 \\
\hline
\end{tabular}

Depressurization time $(\min )$ :

19 


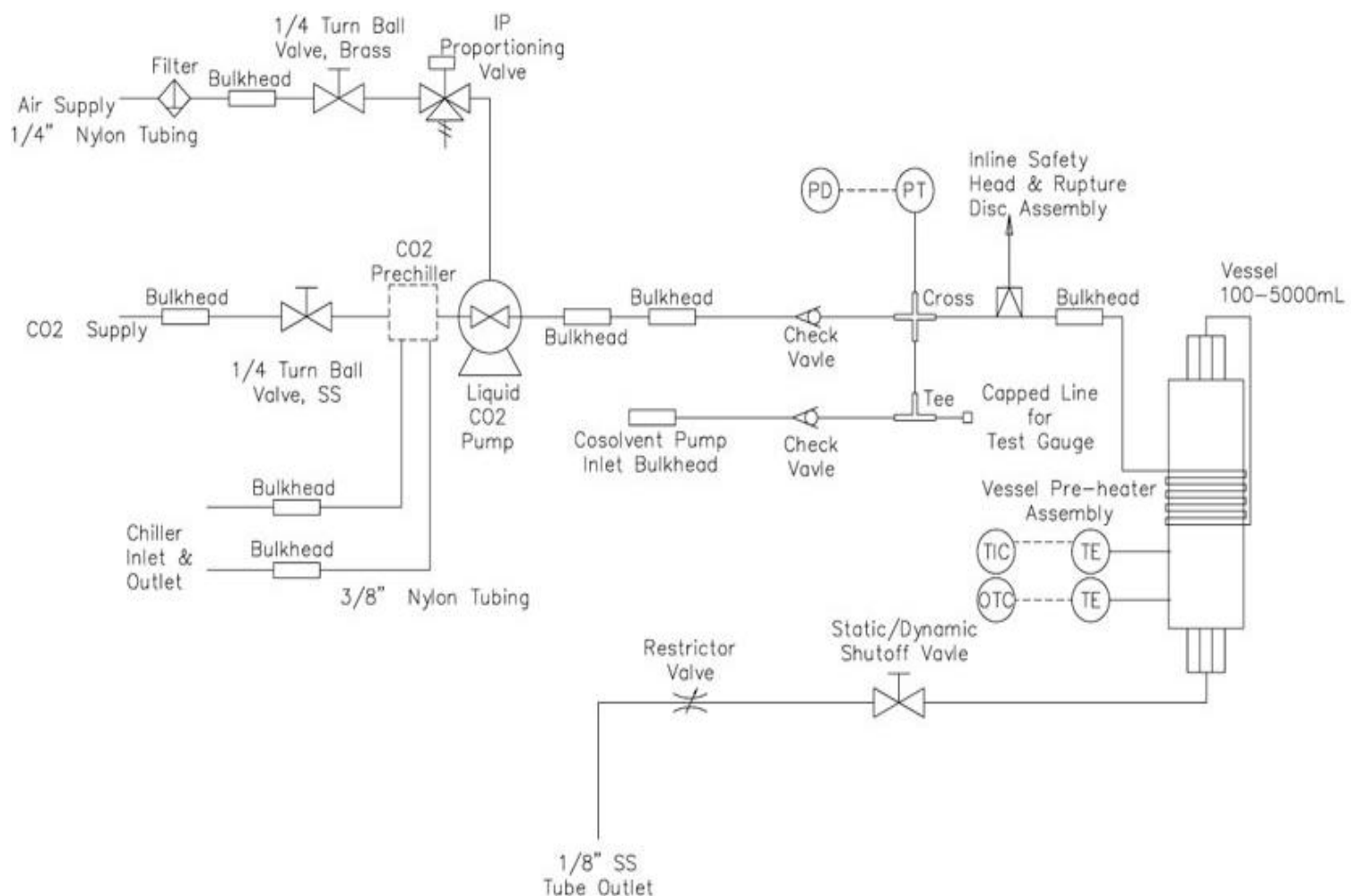

Figure C-1: Flow Diagram of SFE Equipment 


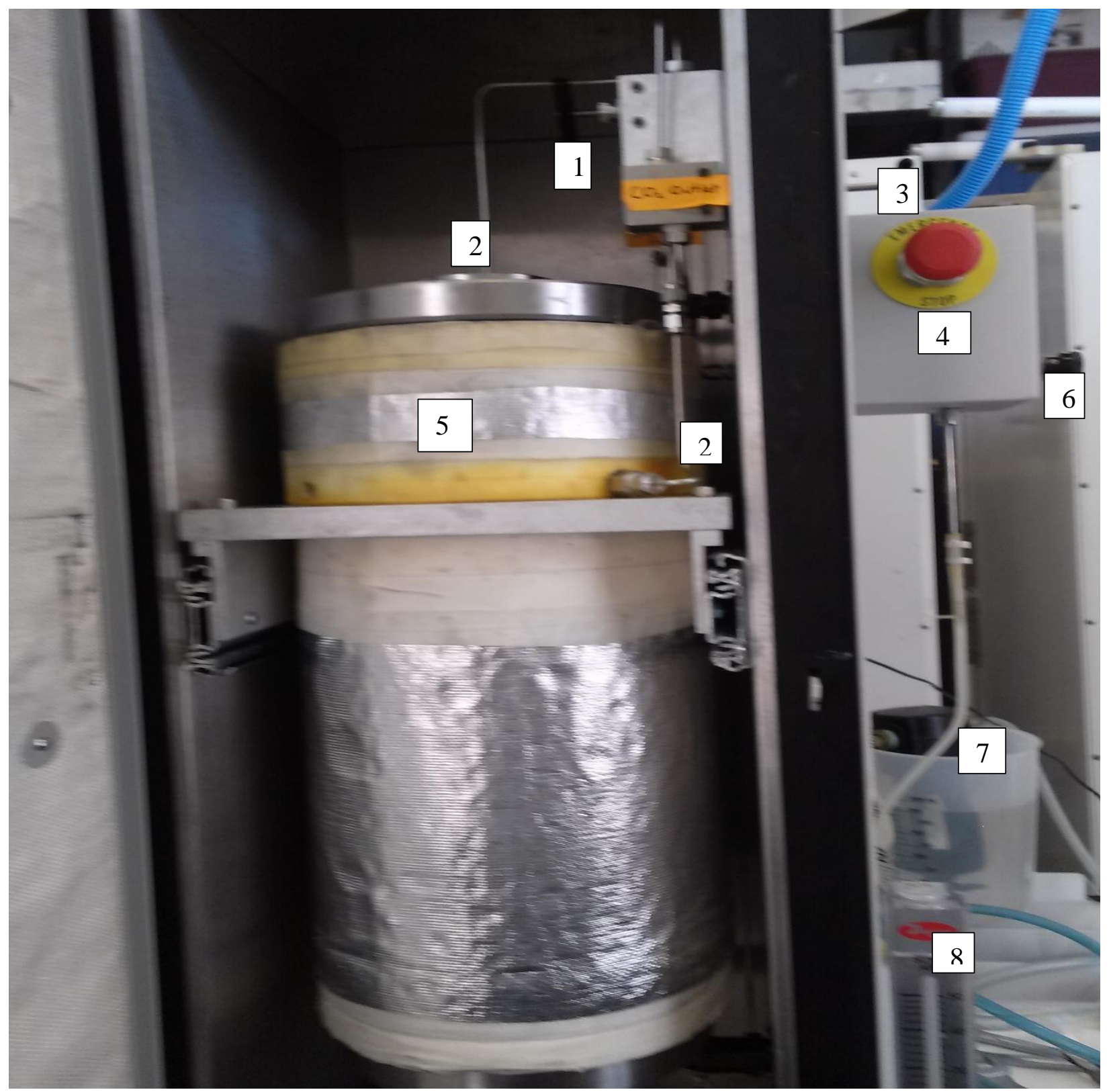

Figure C-2: Picture of SFE Equipment (Vessel) 


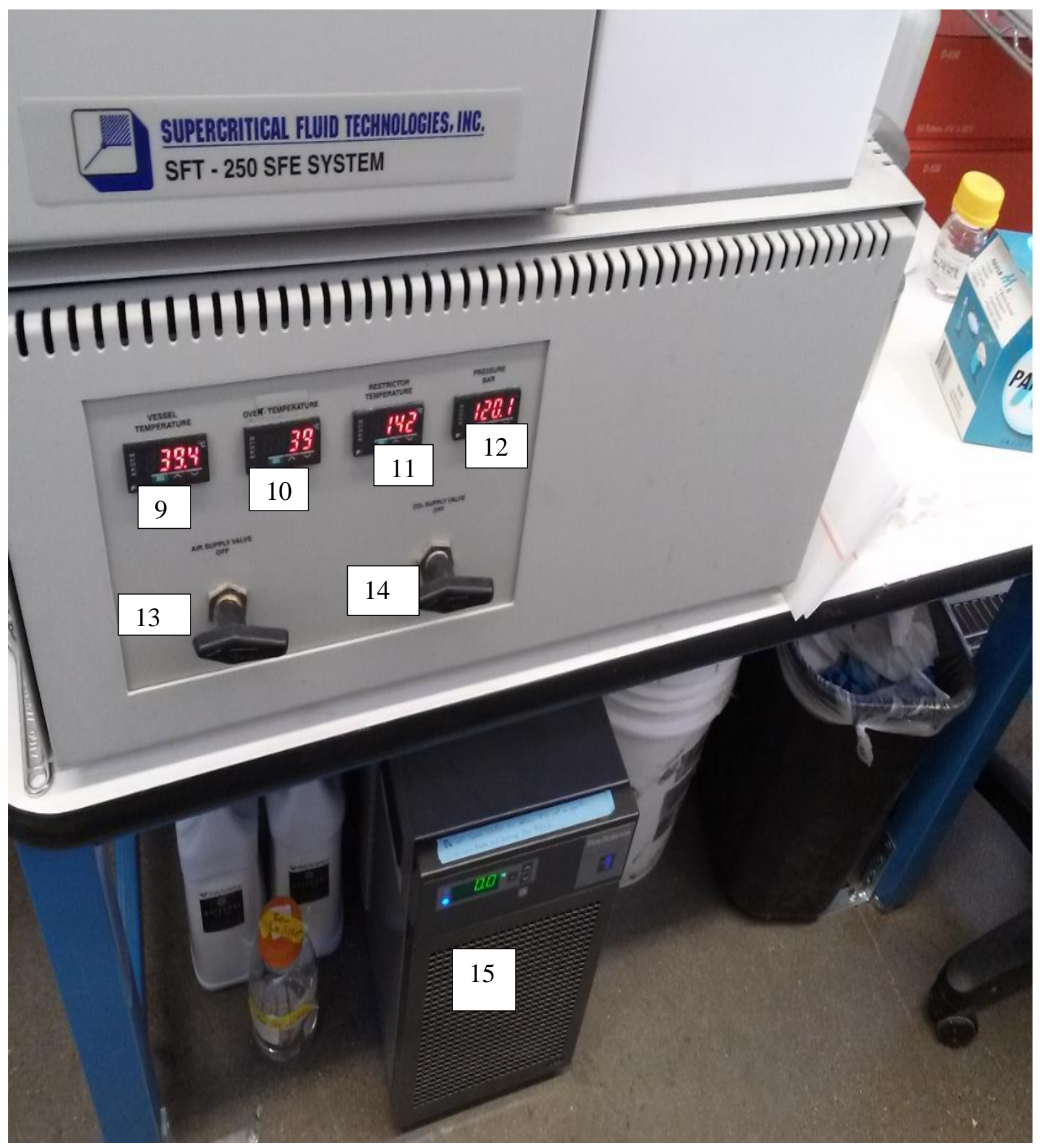

Figure C-3: Picture of SFE Equipment 


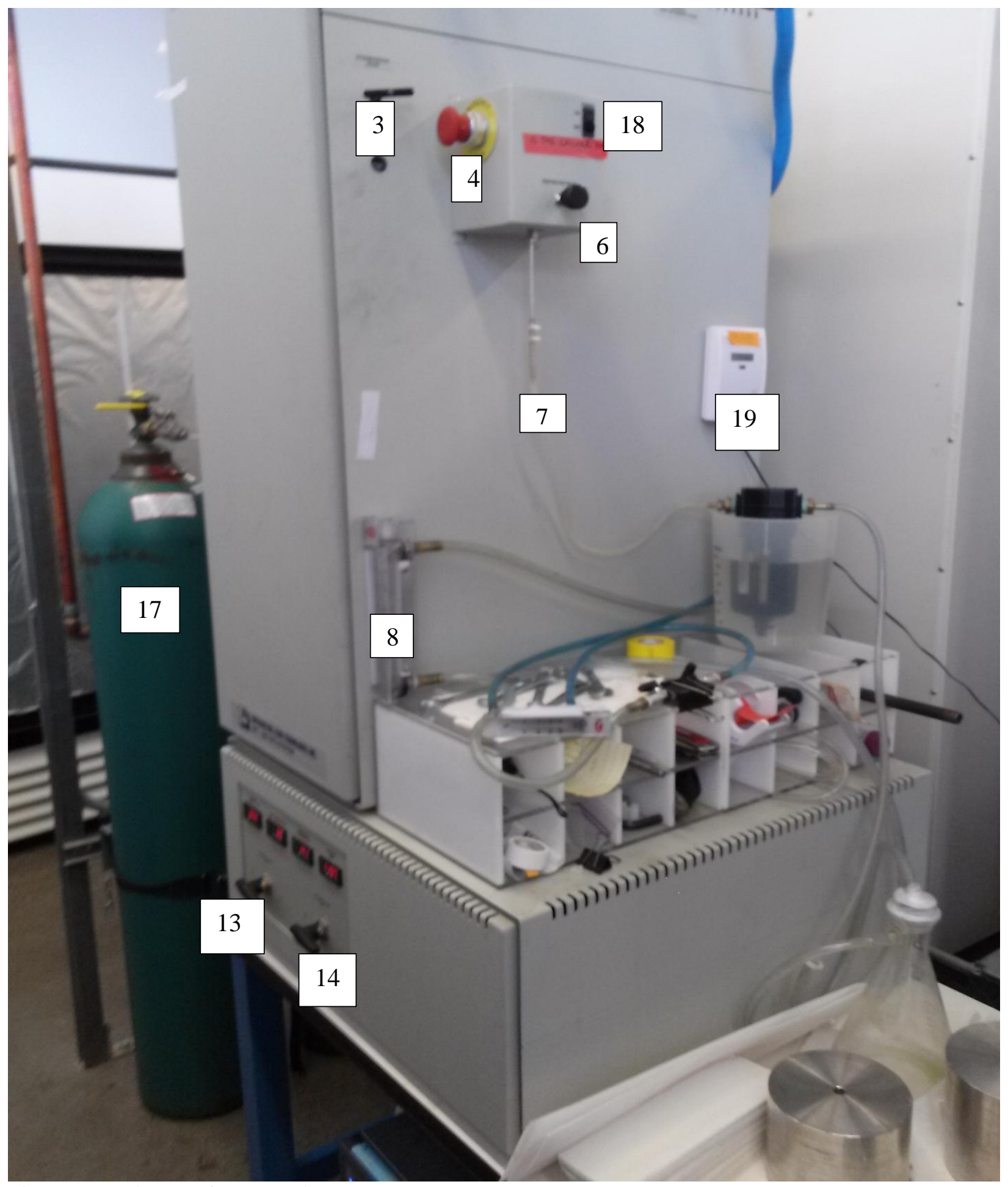

Figure C-4: Picture of SFE Equipment 


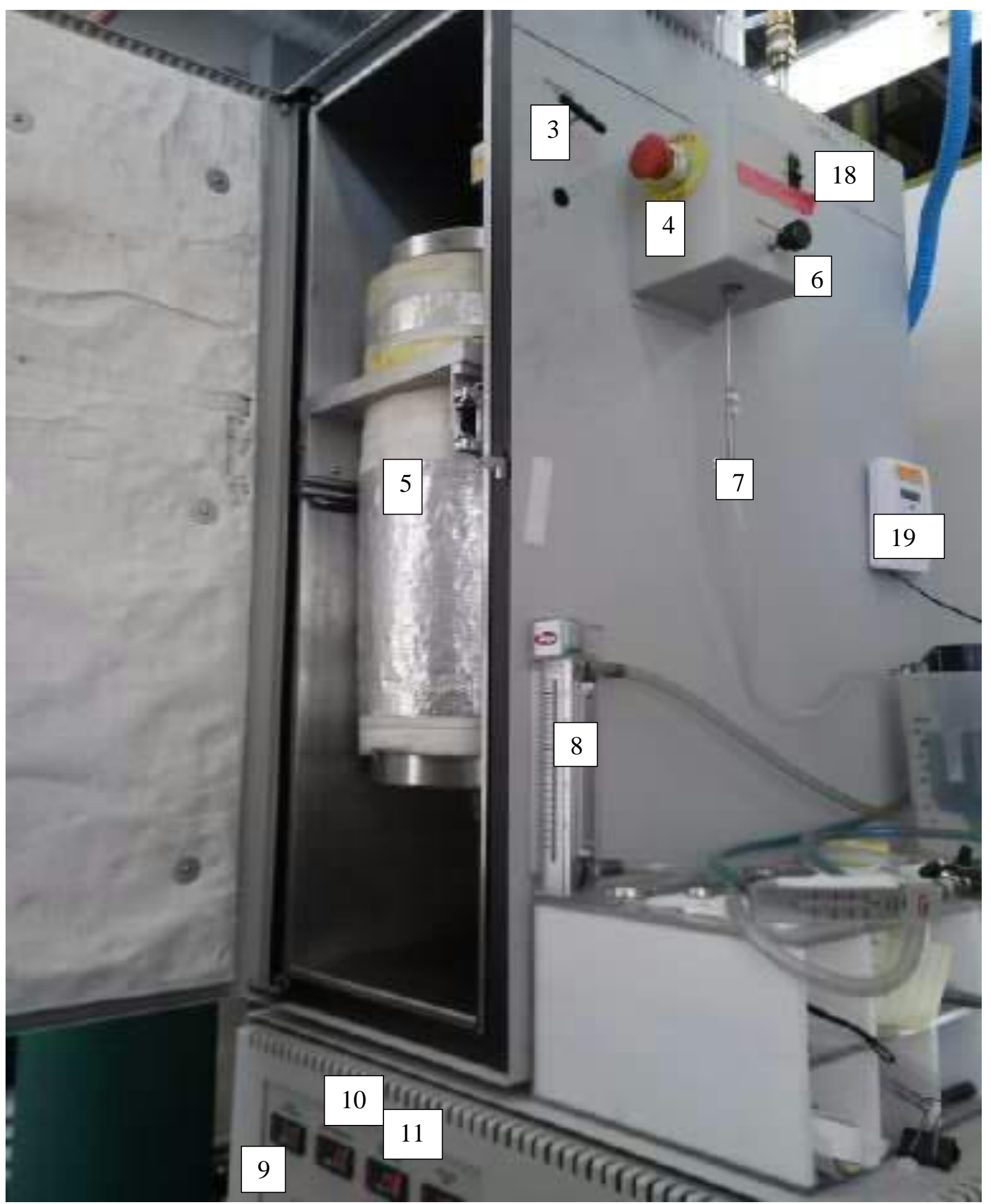

Figure C-5: Picture of SFE Equipment 


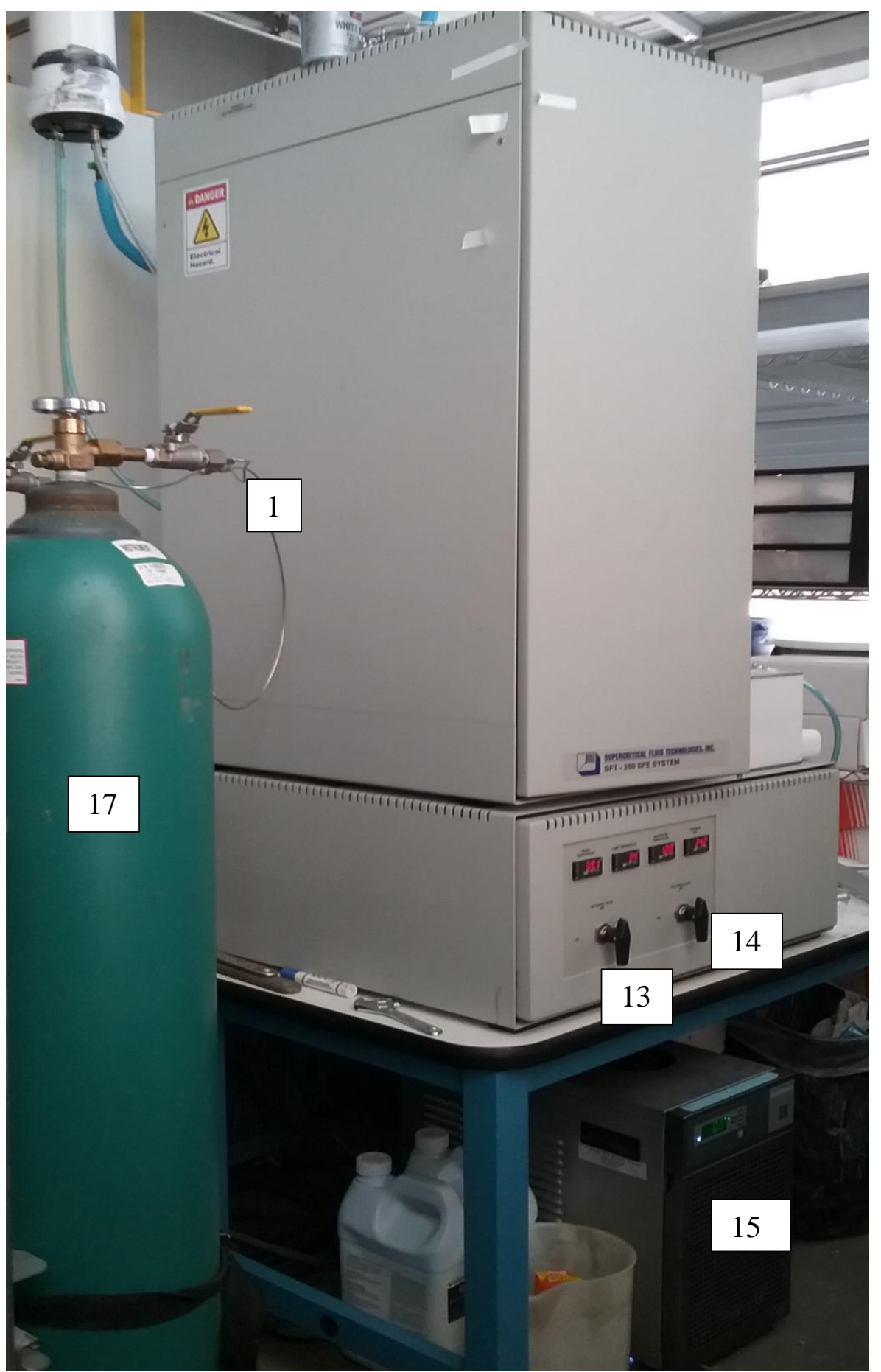

Figure C-6: Picture of SFE Equipment 


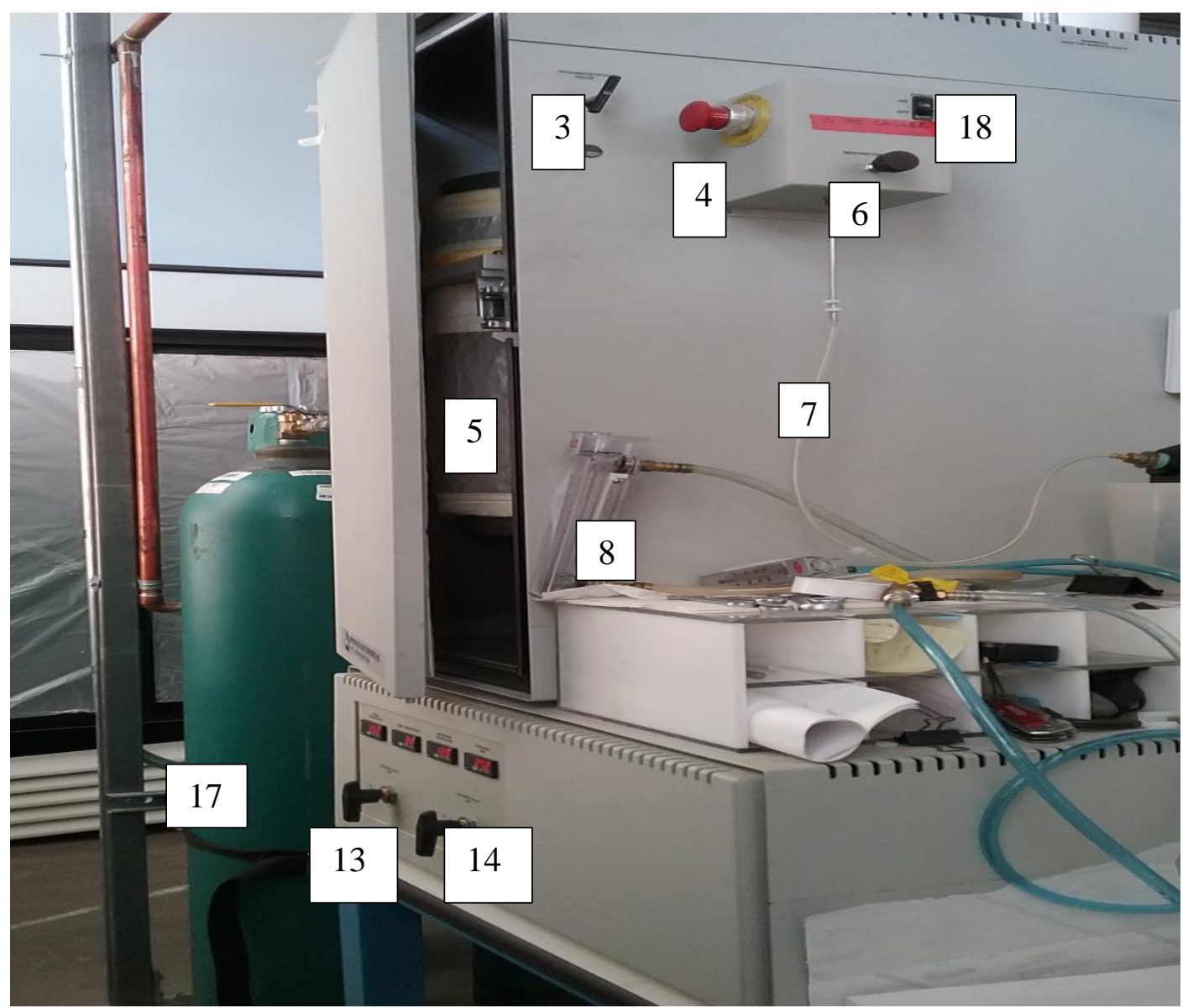

Figure C-7: Picture of SFE Equipment

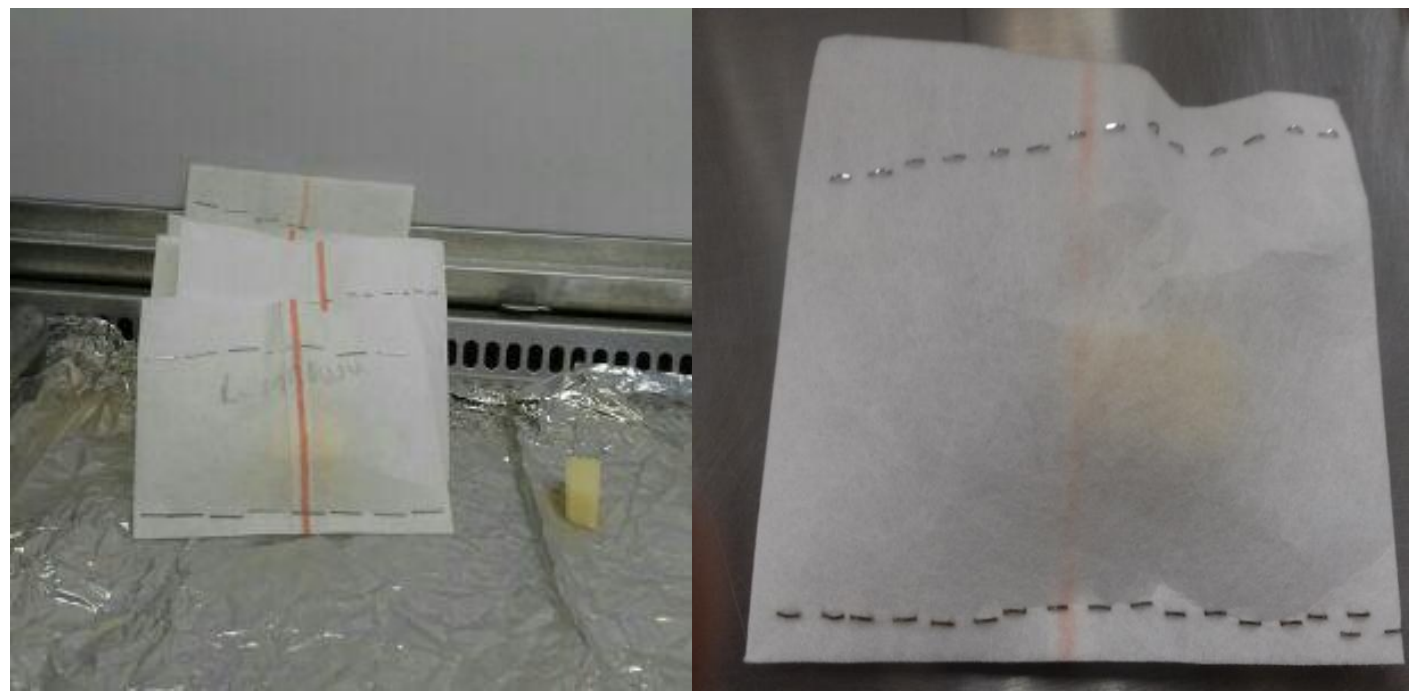

Figure C-8: Sealed pouch used in SFE treatment 
1: Quick release exhaust valve

\section{Parts of the SFE Equipment}

2: $\mathrm{CO}_{2}$ outlet

3: Static dynamic valve

4: Emergency stop bottom

5: Vessel with 5 Lt Capacity

6: Restrictor valve

7: Restrictor valve outlet

8: Flowmeter

9: Oven temperature reader

10: Vessel temperature reader

11: Restrictor valve temperature reader

12: Pressure reader

13: Air supply valve

14: $\mathrm{CO}_{2}$ supply valve

15: Chiller

16: $\mathrm{CO}_{2}$ valves

17: $\mathrm{CO}_{2} \operatorname{tank}$

18: Turn on/off switch

19: $\mathrm{CO}_{2}$ alarm 